\title{
Modeling natural emissions in the Community Multiscale Air Quality (CMAQ) model - Part 2: Modifications for simulating natural emissions
}

\author{
S. F. Mueller, Q. Mao, and J. W. Mallard \\ Tennessee Valley Authority, P.O. Box 1010, Muscle Shoals, Alabama 35662-1010, USA \\ Received: 28 May 2010 - Published in Atmos. Chem. Phys. Discuss.: 28 June 2010 \\ Revised: 10 December 2010 - Accepted: 17 December 2010 - Published: 14 January 2011
}

\begin{abstract}
The Community Multiscale Air Quality (CMAQ) model version 4.6 has been revised with regard to the representation of chlorine $\left(\mathrm{HCl}, \mathrm{ClNO}_{2}\right)$ and sulfur (dimethylsulfide, or DMS, and $\mathrm{H}_{2} \mathrm{~S}$ ), and evaluated against observations and earlier published models. Chemistry parameterizations were based on published reaction kinetic data and a recently developed cloud chemistry model that includes heterogeneous reactions of organic sulfur compounds. Evaluation of the revised model was conducted using a recently enhanced data base of natural emissions that includes ocean and continental sources of DMS, $\mathrm{H}_{2} \mathrm{~S}$, chlorinated gases and lightning $\mathrm{NO}_{\mathrm{x}}$ for the continental United States and surrounding regions. Results using 2002 meteorology and emissions indicated that most simulated "natural" (plus background) chemical and aerosol species exhibit the expected seasonal variations at the surface. Ozone exhibits a winter and early spring maximum consistent with ozone data and an earlier published model. Ozone distributions reflect the influences of atmospheric dynamics and pollutant background levels imposed on the CMAQ simulation by boundary conditions derived from a global model. A series of model experiments reveals that the consideration of gas-phase organic sulfur chemistry leads to sulfate aerosol increases over most of the continental United States. Cloud chemistry parameterization changes result in widespread decreases in $\mathrm{SO}_{2}$ across the modeling domain and both increases and decreases in sulfate. Most cloud-mediated sulfate increases occurred mainly over the Pacific Ocean (up to about $0.1 \mu \mathrm{g} \mathrm{m}^{-3}$ ) but also over and downwind from the Gulf of Mexico (including parts of the eastern US). Geographic variations in simulated $\mathrm{SO}_{2}$ and sulfate are due to the link between $\mathrm{DMS} / \mathrm{H}_{2} \mathrm{~S}$ and their byproduct $\mathrm{SO}_{2}$, the heterogeneity of cloud cover and precipitation
\end{abstract}

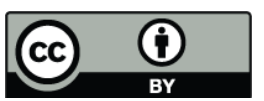

Correspondence to: S. F. Mueller (sfmueller@tva.gov) (precipitating clouds act as net sinks for $\mathrm{SO}_{2}$ and sulfate), and the persistence of cloud cover (the largest relative sulfate increases occurred over the persistently cloudy Gulf of Mexico and western Atlantic Ocean). Overall, the addition of organic sulfur chemistry increased hourly surface sulfate levels by up to $1-2 \mu \mathrm{g} \mathrm{m}^{-3}$ but reduced sulfate levels in the vicinity of high $\mathrm{SO}_{2}$ emissions (e.g., wildfires). Simulated surface levels of DMS compare reasonably well with observations in the marine boundary layer where DMS oxidation product levels are lower than observed. This implies either a low bias in model oxidation rates of organic sulfur species or a low bias in the boundary conditions for DMS oxidation products. This revised version of CMAQ provides a tool for realistically simulating the influence of natural emissions on air quality.

\section{Introduction}

Natural contributions to air pollution are important in determining overall human and ecosystem exposures to potentially damaging pollutants, and set limits to and benchmarks for the pollutant reduction objectives at the heart of air pollution policy and regulations (Chameides et al., 1988; EPA, 2003; Kaynak et al., 2008; Smith and Mueller, 2010). Examples of the importance of naturally occurring pollutants include the United States guidelines for implementing the Regional Haze Rule (EPA, 2003), and the interest in background pollutant levels for their potential impact on achieving US air quality standards (Lin et al., 2000; EPA, 2005). Natural pollutants often cannot be distinguished from those derived from man-made emissions. Consequently, air quality models are used to identify the relative contributions from different source classes.

Published by Copernicus Publications on behalf of the European Geosciences Union. 
The Community Multiscale Air Quality (CMAQ) Model, developed by the US Environmental Protection Agency (EPA), is typically used to examine the formation and transport of ozone and airborne particles. The EPA Models-3 air quality modeling system - including the SMOKE emissions and CMAQ air quality components - simulates pollutants emitted from both anthropogenic and natural processes and systems. Common natural pollutants in SMOKE/CMAQ are biogenic emissions of volatile organic compounds (VOCs) emitted by vegetation, soil NO emissions, gaseous and particulate emissions from wildfires, and animal-derived $\mathrm{NH}_{3}$. Recently, windblown dust emissions were added using the model of Mansell et al. (2006). In addition, beginning with version 4.6 (denoted "CMAQ4.6"), CMAQ performs an internal computation of sea salt particle emissions. These natural emission treatments in the SMOKE/CMAQ4.6 system are incomplete, however.

Berntsen and Isaksen (1997) modeled global tropospheric photochemistry based on the Global Emissions Inventory Activity (GEIA) emissions data base (http://www.geiacenter. org/). This data base includes both anthropogenic and natural emissions, the latter including fluxes from biomass burning, biogenic sources (vegetation VOCs and soil NO), lightning $\mathrm{NO}_{\mathrm{x}}\left(\mathrm{LNO}_{\mathrm{x}}\right)$ and oceans [dimethylsulfide (DMS), $\mathrm{NH}_{3}, \mathrm{HCl}$ and $\mathrm{ClNO}_{2}$ ]. However, given the focus of Berntsen and Isaksen (1997) on ozone it is not clear to what extent their modeling used all the emissions species that are currently available.

Park et al. (2004) used GEOS-Chem to simulate atmospheric aerosols derived in part from natural sulfur emissions from oceans (DMS) and volcanoes; $\mathrm{NO}_{\mathrm{x}}$ from lightning, vegetation, and soils; biomass burning emissions (including $\mathrm{CO}, \mathrm{NO}_{\mathrm{x}}$ and VOCs); and ammonia emitted by animals. Likewise, Kaminski et al. (2008) used data from the EDGAR 2.0 and GEIA emissions inventories for their global air quality modeling effort including emissions from these same sources. They incorporated monthly mean totals of $\mathrm{LNO}_{\mathrm{x}}$ from the GEIA data base, scaling emission horizontally according to the modeled distribution of convective clouds and vertically following profiles reported by Pickering et al. (1993).

Koo et al. (2010) recently examined potential air quality impacts of selected natural emissions not normally treated in the CMAQ Model. They added lightning $\mathrm{NO}_{\mathrm{x}}$ and surrogates for organosulfur from oceans. Their approach to estimating $\mathrm{LNO}_{\mathrm{x}}$ emissions started with an annual estimate to total $\mathrm{LNO}_{\mathrm{x}}$ emitted across the United States followed by a spatialtemporal allocation scheme based on simulated convective precipitation. Organosulfur species DMS and methanesulfonic acid (MSA) were treated using ocean emissions estimates from the global GEOS-Chem model, and by using $\mathrm{SO}_{2}$ as a surrogate for DMS and sulfate as a surrogate for MSA. This approach avoided the need for modifying the model chemistry but poses questions about the validity of their assumptions. Koo et al. (2010) concluded that $\mathrm{LNO}_{\mathrm{x}}$ contributes significantly (1-6 ppbV) to annual average ozone levels, especially across the southeastern US. They also determined that their scheme for estimating organosulfur pollutants decreased ozone slightly (due to the added sulfur reacting with $\mathrm{OH}$ ) in the vicinity of the emissions and increased fine particle mass by amounts generally $<0.25 \mu \mathrm{g} \mathrm{m}^{-3}$ on an annual average.

Reduced sulfur (DMS and $\mathrm{H}_{2} \mathrm{~S}$ ) emissions from oceans and geogenic sources, overlooked in CMAQ, are considered an important source of marine aerosols (Kreidenweis et al., 1991). Though relatively small compared to the oceans, inland lakes and coastal wetlands are also important sources of DMS and $\mathrm{H}_{2} \mathrm{~S}$ (NAPAP, 1991). Geogenic sources - especially the thermal vents of geologically active regions like Yellowstone National Park - emit $\mathrm{H}_{2} \mathrm{~S}$ that may be important contributors to downwind aerosols. Emissions from volcanoes were generally not included due to the sporadic nature of their emissions.

Gas-phase Chemistry: Kreidenweis et al. (1991) used a photochemical model with 72 chemical reactions (and 12 photolysis reactions) to examine sulfate aerosol formation in the marine environment. However, their model contained only one reaction involving DMS oxidation by $\mathrm{OH}$ with $\mathrm{SO}_{2}$ and MSA as products. This highly simplified approach was sufficient to produce a latitudinal gradient in marine sulfate similar to that reported from some measurement studies. No reactions were included that treated $\mathrm{H}_{2} \mathrm{~S}$.

Yin et al. (1990) developed a comprehensive model of DMS and its derivatives. Their mechanism included 40 sulfur species and 140 reactions. Zaveri (1997) simplified the Yin et al. mechanism (10 organic sulfur species and 30 reactions) for use in a large-scale atmospheric model. The Zaveri model retained the major oxidation pathways from its more complex progenitor, but several reactions were combined and/or simplified to reduce computational requirements. Zaveri's work focused most attention on the fate of two radicals formed as part of the DMS-to-sulfate channels: $\mathrm{CH}_{3} \mathrm{SO}_{2}$ and $\mathrm{CH}_{3} \mathrm{SO}_{3}$. The reason for this is that $\mathrm{CH}_{3} \mathrm{SO}_{2}$ is formed as part of several reaction channels (while $\mathrm{CH}_{3} \mathrm{SO}_{3}$ is produced from some reactions involving $\mathrm{CH}_{3} \mathrm{SO}_{2}$ ) but its fate has been less certain than other intermediate species. The uncertainty is due to the relative importance of the thermal decomposition of $\mathrm{CH}_{3} \mathrm{SO}_{2}$ to $\mathrm{CH}_{3}$ and $\mathrm{SO}_{2}$, versus reactions of $\mathrm{CH}_{3} \mathrm{SO}_{2}$ with species such as $\mathrm{NO}_{2}, \mathrm{O}_{3}$ and $\mathrm{HO}_{2}$. Prior to Zaveri's work, different laboratory studies of this decomposition yielded rates that differed by a factor of $3 \times 10^{5}$. Clearly, this uncertainty - plus the uncertainty of the rate constants for chemical reactions involving $\mathrm{CH}_{3} \mathrm{SO}_{2}$ - made it difficult to know whether these reactions were of sufficient significance to include in a mechanism for marine sulfate. Zaveri concluded that the competing reactions were important and included them (plus reactions involving $\mathrm{CH}_{3} \mathrm{SO}_{3}$ ) in his mechanism.

The primary features of the Yin et al. mechanism, the Zaveri mechanism, and mechanisms used by Lucas and Prinn (2005) and Zhu et al. (2006), are essentially the same 
although differences exist in the rate constants and branching or partitioning ratios for some of the reactions. DMS is initially attacked by $\mathrm{OH}$ with two reaction channels (all mechanisms), $\mathrm{NO}_{3}$ (all mechanisms) and $\mathrm{O}$ (Yin et al. and Zaveri mechanisms). One DMS + OH channel produces dimethylsulfoxide (DMSO), dimethylsulfone (DMSO2), methanesulfinic acid (MSIA) and MSA (only the Lucas and Prinn mechanism includes DMSO2). The other $\mathrm{OH}$ channel leads to the formation of the hydroperoxy radical $\mathrm{CH}_{3} \mathrm{SCH}_{2} \mathrm{OO}$ which undergoes further reactions that produce $\mathrm{CH}_{3} \mathrm{~S}$ and, ultimately, $\mathrm{SO}_{2}$ and $\mathrm{H}_{2} \mathrm{SO}_{4}$ (all but the Lucas and Prinn mechanism). Only the Yin et al. and Zaveri mechanisms include reactions for $\mathrm{CH}_{3} \mathrm{SO}_{2}$ and $\mathrm{CH}_{3} \mathrm{SO}_{3}$.

A study by Kukui et al. (2000) - published after Yin et al. (1990) and Zaveri (1997), and too late to be included in the overview of Finlayson-Pitts and Pitts (2000) - examined in detail the issue of $\mathrm{CH}_{3} \mathrm{SO}_{2}$ thermal decomposition. Kukui et al. (2000) measured $\mathrm{CH}_{3} \mathrm{SO}_{2}$ behavior and their data, coupled with theory, were used to develop a mathematical expression for $\mathrm{CH}_{3} \mathrm{SO}_{2}$ thermal decomposition as a function of temperature and pressure. This expression represents the $\mathrm{CH}_{3} \mathrm{SO}_{2}$ loss rate throughout the troposphere for comparison with $\mathrm{CH}_{3} \mathrm{SO}_{2}$ loss rates for its reactions with $\mathrm{NO}_{2}, \mathrm{O}_{3}$ and $\mathrm{HO}_{2}$ at realistic concentrations based on the rate constants used by Zaveri (1997). The pressure/temperature effect on thermal decomposition was examined for a range of conditions that can occur between the ground and the top of the troposphere. Colder temperatures in the upper troposphere significantly reduce $\mathrm{CH}_{3} \mathrm{SO}_{2}$ decomposition. However, the loss rate due to decomposition in the troposphere is almost always at least a factor of ten greater than loss rates from reactions with $\mathrm{NO}_{2}, \mathrm{O}_{3}$ and $\mathrm{HO}_{2}$. Based on this, it seems that including reactions involving $\mathrm{CH}_{3} \mathrm{SO}_{2}$ and $\mathrm{CH}_{3} \mathrm{SO}_{3}$ in a chemical mechanism is likely a computational luxury that many models cannot afford.

Chlorine Compounds: over the oceans halogens, especially chlorine, comprise an important source of reactive compounds (Smith and Mueller, 2010). In this environment away from continental pollutants, emissions of reduced sulfur species such as DMS and $\mathrm{H}_{2} \mathrm{~S}$ react primarily with $\mathrm{OH}$ in the atmosphere but their oxidation is accelerated in the presence of $\mathrm{HCl}$ and $\mathrm{ClNO}_{2}$. Chlorine reactants originate from the nighttime heterogeneous reaction of $\mathrm{N}_{2} \mathrm{O}_{5}$ with sea salt aerosols - releasing $\mathrm{ClNO}_{2}$ (Behnke et al., 1997) - and from other reactions involving sea salt aerosols and producing chlorine gas and $\mathrm{HCl}$ (Knipping and Dabdub, 2003). Chlorine gas photolyzes in the atmosphere to atomic chlorine and $\mathrm{ClNO}_{2}$ reacts with $\mathrm{OH}$ to form $\mathrm{HOCl}$ and $\mathrm{NO}_{2}$ (Atkinson et al., 2007):

$$
\mathrm{OH}+\mathrm{ClNO}_{2} \rightarrow \mathrm{HOCl}+\mathrm{NO}_{2}
$$

Thus, $\mathrm{ClNO}_{2}$ is a reservoir of $\mathrm{NO}_{2}$ in the marine boundary layer and provides reactive $\mathrm{HOCl}$ that further photolyzes in the gas phase to $\mathrm{OH}$ and $\mathrm{Cl}$. Nitryl chloride is produced at levels roughly 100 times lower than $\mathrm{HCl}$ (Erickson et al.,
1999). Ambient concentrations of $\mathrm{Cl}$ are generally low except in areas affected by anthropogenic chlorine and/or $\mathrm{NO}_{\mathrm{x}}$ emissions. Table 1 lists Reaction (R1) along with several reactions believed by Tanaka and Allen (2001) to be important in tropospheric chemistry for chlorine species. Note that $\mathrm{HCl}$ can be an important contributor to cloud droplet acidity in the marine environment and aqueous $\mathrm{Cl}^{-}$plays a role in the droplet balance of various chlorine species in clouds.

$\mathrm{H}_{2} \mathrm{~S}$ : atmospheric oxidation of $\mathrm{H}_{2} \mathrm{~S}$ proceeds following a variety of gas-phase reactions involving many of the same species important for other photochemistry. Kinetic data exist for reactions of $\mathrm{H}_{2} \mathrm{~S}$ with $\mathrm{OH}, \mathrm{O}, \mathrm{HO}_{2}, \mathrm{Cl}$ and $\mathrm{NO}_{3}$. Each of the $\mathrm{OH}, \mathrm{O}$ and $\mathrm{Cl}$ radicals is known to attack the $\mathrm{S}$ bond with $\mathrm{H}$ and produce the $\mathrm{SH}$ radical. Both $\mathrm{HO}_{2}$ and $\mathrm{NO}_{3}$ are likely to act similarly on $\mathrm{H}_{2} \mathrm{~S}$ although their reaction products have not been directly identified. The rate constant for $\mathrm{H}_{2} \mathrm{~S}+\mathrm{Cl}$ has been measured to be the highest $\left(7.4 \times 10^{-11} \mathrm{~cm}^{3}\right.$ molecule ${ }^{-1} \mathrm{~s}^{-1}$ at $298 \mathrm{~K}$ ) of this set of reactions. The next highest rate constants are for reactions involving $\mathrm{OH}$ and $\mathrm{O}$ (at $298 \mathrm{~K}$ ): $k \approx 5 \times 10^{-12} \mathrm{~cm}^{3}$ molecule $\mathrm{e}^{-1} \mathrm{~s}^{-1}$ for the $\mathrm{OH}$ reaction is about two orders of magnitude greater than that for the $\mathrm{O}$ reaction (NASA, 1997). Upper limits to the rate constants for the reactions involving $\mathrm{HO}_{2}$ and $\mathrm{NO}_{3}$ are both $\sim 1 \times$ $10^{-15} \mathrm{~cm}^{3}$ molecule ${ }^{-1} \mathrm{~s}^{-1}$ (Atkinson et al., 2004). During daytime, the reaction of $\mathrm{H}_{2} \mathrm{~S}$ with $\mathrm{OH}$ will dominate over that with $\mathrm{O}$, while the reaction with $\mathrm{Cl}$ could be important over the ocean and in the presence of chlorine emissions. At night, the reaction with $\mathrm{NO}_{3}$ will most likely be the dominant pathway for initiating the breakdown of $\mathrm{H}_{2} \mathrm{~S}$ with assumed products (by analogy with the other reactions) of $\mathrm{SH}$ and nitric acid. Table 2 summarizes noteworthy $\mathrm{H}_{2} \mathrm{~S}$ and related reactions along with relevant kinetic data and literature citations.

SH Reactions: the second step in oxidizing $\mathrm{H}_{2} \mathrm{~S}$ in the atmosphere involves reactions of $\mathrm{SH}$. Data exist on the kinetics of $\mathrm{SH}$ reactions with $\mathrm{O}, \mathrm{O}_{2}, \mathrm{O}_{3}, \mathrm{NO}, \mathrm{NO}_{2}, \mathrm{Cl}_{2}$ and $\mathrm{H}_{2} \mathrm{O}_{2}$, as well as various bromine and fluorine species (NASA, 1997). At $298 \mathrm{~K}$, rate constants $k_{i}$ for $\mathrm{SH}$ reactions with species $i$ are as follows (all have units of $\mathrm{cm}^{3}$ molecule $\left.{ }^{-1} \mathrm{~s}^{-1}\right): k_{O}=1.6 \times 10^{-10} ; k_{\mathrm{O}_{2}}<4 \times 10^{-19}$; $k_{\mathrm{O}_{3}}=3.7 \times 10^{-12} ; k_{\mathrm{NO}_{2}}=6.5 \times 10^{-11} ; k_{C l 2}=1.7 \times 10^{-10}$; $k_{\mathrm{H}_{2} \mathrm{O}_{2}}<5 \times 10^{-15}$. The reaction $\mathrm{SH}+\mathrm{NO}+\mathrm{M}$ has a more complex rate constant expression that is a function of altitude (pressure) in the atmosphere. At sea level and $298 \mathrm{~K}$ $k_{N O}=2.6 \times 10^{-12} \mathrm{~cm}^{3}$ molecule $\mathrm{s}^{-1} \mathrm{~s}^{-1}$. The slowest reaction is by far $\mathrm{SH}+\mathrm{O}_{2}$, but the abundance of $\mathrm{O}_{2}$ as a reactant makes it competitive with most other trace species as an important pathway for $\mathrm{SH}$ removal. The reaction with $\mathrm{H}_{2} \mathrm{O}_{2}$ appears to be the least important overall (note that Friedl et al., 1985, reported finding little net production of product species $\mathrm{HSO}$ from this reaction). Reactions involving $\mathrm{NO}$ and $\mathrm{NO}_{2}$ will be important only downwind of $\mathrm{NO}_{\mathrm{x}}$ emission sources. $\mathrm{SH}$ reactions with $\mathrm{O}$ and $\mathrm{O}_{2}$ produce the $\mathrm{SO}$ radical whereas reaction with $\mathrm{O}_{3}$ and $\mathrm{NO}_{2}$ produce $\mathrm{HSO}$. Reaction with $\mathrm{NO}$ 
Table 1. Chlorine reactions with importance to tropospheric gas-phase chemistry ${ }^{\mathrm{a}}$.

\begin{tabular}{|c|c|}
\hline Reaction $^{\mathrm{b}}$ & $\begin{array}{l}\text { Rate Constant }{ }^{\mathrm{c}}, k \\
\left(\mathrm{~cm}^{3} \text { molecule }^{-1} \mathrm{~s}^{-1}\right)\end{array}$ \\
\hline $\mathrm{Cl}_{2}+h v \rightarrow 2 \mathrm{Cl}$ & $0.264 k_{\mathrm{NO}_{2}}$ \\
\hline $\mathrm{HOCl}+h v \rightarrow \mathrm{OH}+\mathrm{Cl}$ & $0.51 k_{\mathrm{ACRO}}$ \\
\hline $\mathrm{PAR}+\mathrm{Cl} \rightarrow \mathrm{HCl}+0.87 \mathrm{XO}_{2}+0.13 \mathrm{XO} 2 \mathrm{~N}+0.11 \mathrm{HO}_{2}+0.11 \mathrm{ALD} 2+0.76 \mathrm{ROR}-0.11 \mathrm{PAR}$ & $78 k_{\mathrm{OH}+\mathrm{PAR}}$ \\
\hline $\mathrm{OLE}+\mathrm{Cl} \rightarrow \mathrm{FMCL}+\mathrm{ALD} 2+2 \mathrm{XO}_{2}+\mathrm{HO}_{2}-\mathrm{PAR}$ & $20 k_{\mathrm{OH}+\mathrm{OLE}}$ \\
\hline $\mathrm{CH}_{4}+\mathrm{Cl} \rightarrow \mathrm{HCl}+\mathrm{XO}_{2}+\mathrm{HCHO}+\mathrm{HO}_{2}$ & $6.6 \times 10^{-12} \exp (-1240 / T)$ \\
\hline $\mathrm{ETH}+\mathrm{Cl} \rightarrow 2 \mathrm{XO}_{2}+\mathrm{HCHO}+\mathrm{FMCL}+\mathrm{HO}_{2}$ & $12.6 k_{\mathrm{OH}}+\mathrm{ETH}$ \\
\hline $\mathrm{ISOP}+\mathrm{Cl} \rightarrow 0.15 \mathrm{HCl}+\mathrm{XO}_{2}+\mathrm{HO}_{2}+0.28 \mathrm{ICL} 1$ & $4.5 k_{\mathrm{OH}+\mathrm{ISOP}}$ \\
\hline $\mathrm{ICL} 1+\mathrm{OH} \rightarrow \mathrm{ICL} 2$ & $0.19 k_{\mathrm{OH}+\mathrm{ISOP}}$ \\
\hline $\mathrm{Cl}+\mathrm{O}_{3} \rightarrow \mathrm{ClO}+\mathrm{O}_{2}$ & $2.9 \times 10^{-11} \exp (-260 / T)$ \\
\hline $\mathrm{ClO}+\mathrm{NO} \rightarrow \mathrm{Cl}+\mathrm{NO}_{2}$ & $6.2 \times 10^{-12} \exp (295 / T)$ \\
\hline $\mathrm{ClO}+\mathrm{HO}_{2} \rightarrow \mathrm{HOCl}+\mathrm{O}_{2}$ & $4.6 \times 10^{-13} \exp (710 / T)$ \\
\hline $\mathrm{ClNO}_{2}+\mathrm{OH} \rightarrow \mathrm{HOCl}+\mathrm{NO}_{2}$ & $2.4 \times 10^{-12} \exp (-1250 / T)$ \\
\hline
\end{tabular}

a All but the last reaction are based on Tanaka and Allen (2001). The reaction of $\mathrm{ClNO}_{2}$ with $\mathrm{OH}$ is from Atkinson et al. (2007).

b CMAQ species abbreviations: ACRO=acrolein (in reference to the SAPRC99 chemical mechanism); PAR=paraffin lumped group; OLE=olefin lumped group; ETH=ethene; ISOP = isoprene; $\mathrm{XO} 2 \mathrm{~N}=\mathrm{NO}$ converted to organic nitrate; ALD2 = acetaldehyde carbonyl lumped group; ROR = secondary alkoxy radical; FMCL= formyl chloride; ICL1 = 1chloro-3-methyl-3-butene-2-one; ICL2 = derivative of ICL1.

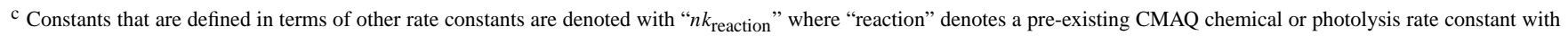
$n$ proportionality factor. Temperature is denoted " $T$ ".

Table 2. Reactions added to CB05 for inorganic sulfur species and their reaction products.

\begin{tabular}{|c|c|c|c|}
\hline Reactants & Products & $\begin{array}{l}\text { Rate Constant } \\
\left(\mathrm{cm}^{3} \text { molecule }{ }^{-1} \mathrm{~s}^{-1}\right)\end{array}$ & Reference \\
\hline $\mathrm{H}_{2} \mathrm{~S}+\mathrm{OH}$ & $\mathrm{SH}+\mathrm{H}_{2} \mathrm{O}$ & $6.0 \times 10^{-12} \exp (-80 / T)$ & Atkinson et al. (2004) \\
\hline $\mathrm{H}_{2} \mathrm{~S}+\mathrm{NO}_{3}$ & $\mathrm{SH}+\mathrm{HNO}_{3}$ & $1.0 \times 10^{-15}$ & Atkinson et al. (2004) \\
\hline $\mathrm{H}_{2} \mathrm{~S}+\mathrm{Cl}$ & $\mathrm{SH}+\mathrm{HCl}$ & $3.7 \times 10^{-11} \exp (208 / T)$ & Atkinson et al. (2004) \\
\hline $\mathrm{SH}+\mathrm{O}$ & $\mathrm{SO}+\mathrm{H}$ & $1.6 \times 10^{-10}$ & NASA (1997) \\
\hline $\mathrm{SH}+\mathrm{O}_{2}$ & $\mathrm{SO}+\mathrm{OH}$ & $4.0 \times 10^{-19}$ & NASA (1997) \\
\hline $\mathrm{SH}+\mathrm{O}_{3}$ & $\mathrm{HSO}+\mathrm{O}_{2}$ & $9.5 \times 10^{-12} \exp (-280 / T)$ & Atkinson et al. (2004) \\
\hline $\mathrm{SH}+\mathrm{NO}_{2}$ & $\mathrm{HSO}+\mathrm{NO}$ & $2.9 \times 10^{-11} \exp (240 / T)$ & Atkinson et al. (2004) \\
\hline $\mathrm{SH}+\mathrm{NO}+\mathrm{M}$ & $\mathrm{HSNO}+\mathrm{M}$ & $\begin{array}{l}k_{0}=2.4 \times 10^{-31}(T / 300)^{-3}[\mathrm{M}] \\
k_{\infty}=2.7 \times 10^{-11^{\mathrm{a}}}\end{array}$ & Atkinson et al. (2004) \\
\hline $\mathrm{SH}+\mathrm{Cl}_{2}$ & $\mathrm{ClSH}+\mathrm{Cl}$ & $1.7 \times 10^{-11} \exp (690 / T)$ & NASA (1997) \\
\hline $\mathrm{HSO}+\mathrm{NO}_{2}$ & $\mathrm{HSO}_{2}+\mathrm{NO}$ & $9.6 \times 10^{-12}$ & NASA (1997) \\
\hline $\mathrm{HSO}+\mathrm{O}_{2}$ & $\mathrm{HSO}_{2}+\mathrm{O}$ & $2.0 \times 10^{-17}$ & Atkinson et al. (2004) \\
\hline $\mathrm{HSO}+\mathrm{O}_{3}$ & $\mathrm{HSO}_{2}+\mathrm{O}_{2}$ & $1.1 \times 10^{-13}$ & Atkinson et al. (2004) \\
\hline $\mathrm{SO}+\mathrm{OH}$ & $\mathrm{SO}_{2}+\mathrm{H}$ & $8.6 \times 10^{-11}$ & NASA (1997) \\
\hline $\mathrm{SO}+\mathrm{O}_{2}$ & $\mathrm{SO}_{2}+\mathrm{O}$ & $1.6 \times 10^{-13} \exp (-2280 / T)$ & Atkinson et al. (2004) \\
\hline $\mathrm{SO}+\mathrm{O}_{3}$ & $\mathrm{SO}_{2}+\mathrm{O}_{2}$ & $4.5 \times 10^{-12} \exp (-1170 / T)$ & Atkinson et al. (2004) \\
\hline $\mathrm{SO}+\mathrm{NO}_{2}$ & $\mathrm{SO}_{2}+\mathrm{NO}$ & $1.4 \times 10^{-11}$ & Atkinson et al. (2004) \\
\hline $\mathrm{SO}+\mathrm{ClO}$ & $\mathrm{SO}_{2}+\mathrm{Cl}$ & $2.8 \times 10^{-11}$ & NASA (1997) \\
\hline $\mathrm{HSO}_{2}+\mathrm{O}_{2}$ & $\mathrm{HO}_{2}+\mathrm{SO}_{2}$ & $3.0 \times 10^{-13}$ & NASA (1997) \\
\hline
\end{tabular}

a Termolecular rate constant expression: $k=\left[\frac{k_{0}}{1+\left(k_{0} / k_{\infty}\right)}\right] 0.6^{\left\{1+\left[\log _{10}\left(k_{0} / k_{\infty}\right)\right]^{2}\right\}^{-1}}$ 
produces $\mathrm{HSNO}$ and reaction with $\mathrm{Cl}_{2}$ produces $\mathrm{ClSH}$. Both $\mathrm{HSNO}$ and $\mathrm{ClSH}$ can be treated as termination products.

SO Reactions: data on reactions of $\mathrm{SO}$ with $\mathrm{OH}, \mathrm{O}_{2}$, $\mathrm{O}_{3}, \mathrm{NO}_{2}$ and $\mathrm{ClO}$ have been reported and all produce $\mathrm{SO}_{2}$ (NASA, 1997). The reaction with $\mathrm{O}_{2}$ is the slowest, but the abundance of $\mathrm{O}_{2}$ makes it important relative to the other reactions. $\mathrm{ClO}$ is a product of the reaction between $\mathrm{Cl}$ and $\mathrm{O}_{3}$.

HSO Reactions: Atkinson et al. (2004) report kinetic rate constants for $\mathrm{HSO}$ reactions with $\mathrm{O}_{2}, \mathrm{O}_{3}, \mathrm{NO}$ and $\mathrm{NO}_{2}$. As with other species, the reaction with $\mathrm{O}_{2}$ is the slowest but the abundance of atmospheric $\mathrm{O}_{2}$ makes it important. HSO reacting with $\mathrm{NO}$ is also very slow compared to the other reactions and is not given further consideration. The reaction of $\mathrm{HSO}+\mathrm{NO}_{2}$ may produce $\mathrm{HSO}_{2}+\mathrm{NO}$ (NASA, 1997) and these products were adopted for use here. HSO reacting with $\mathrm{O}_{2}$ and $\mathrm{O}_{3}$ are assumed to produce $\mathrm{HSO}_{2}$ by analogy with the products of the $\mathrm{NO}_{2}$ reaction. The only reaction identified for removing $\mathrm{HSO}_{2}$ is that with $\mathrm{O}_{2}$, but it is fairly rapid given the levels of $\mathrm{O}_{2}$.

DMS Reactions: a realistic treatment of organic sulfur $\left(S_{\text {org }}\right)$ compounds must consider their reactions with various atmospheric oxidants. Finlayson-Pitts and Pitts (2000) provide a detailed overview of $S_{\text {org }}$ atmospheric chemistry. There is still much that needs to be learned about the kinetics and reaction products for $S_{\text {org }}$ species. Studies have revealed that DMS is relatively reactive with a broad spectrum of chemical species, including $\mathrm{O}_{3}, \mathrm{OH}, \mathrm{HO}_{2}, \mathrm{O}, \mathrm{Cl}, \mathrm{ClO}$, $\mathrm{IO}, \mathrm{BrO}, \mathrm{F}, \mathrm{NO}_{3}$, and $\mathrm{N}_{2} \mathrm{O}_{5}$. Ubiquitous $\mathrm{O}_{3}$ reacts slowly with DMS (rate constant $k<1 \times 10^{-18} \mathrm{~cm}^{3}$ molecule ${ }^{-1} \mathrm{~s}^{-1}$ ). A comparative analysis of the various reactions reveals that DMS reactions with $\mathrm{O}, \mathrm{Cl}, \mathrm{OH}, \mathrm{OH}+\mathrm{O}_{2}$, and $\mathrm{NO}_{3}$ most likely control the fate of DMS in the atmosphere. Reactions with other halogen compounds are probably also important in selected situations but little is known about naturally occurring emissions and atmospheric levels of species like $\mathrm{IO}$ and $\mathrm{BrO}$. Noteworthy is the dual-channel reaction of DMS $\left(\mathrm{CH}_{3} \mathrm{SCH}_{3}\right)$ with $\mathrm{Cl}$ with a rate constant of about $3.3 \times$ $10^{-10} \mathrm{~cm}^{3}$ molecule ${ }^{-1} \mathrm{~s}^{-1}$ at $298 \mathrm{~K}$ and 1 atm (FinlaysonPitts and Pitts, 2000):

$$
\begin{aligned}
\mathrm{Cl}+\mathrm{CH}_{3} \mathrm{SCH}_{3} & \rightarrow \mathrm{HCl}+\mathrm{CH}_{3} \mathrm{SCH}_{2} \\
& \rightarrow \mathrm{CH}_{3} \mathrm{~S}(\mathrm{Cl}) \mathrm{CH}_{3}
\end{aligned}
$$

The reaction of $\mathrm{OH}$ with DMS is perhaps the most studied of all reactions involving DMS and it is one of the most complex. This reaction also occurs by way of two reaction channels:

$$
\begin{aligned}
& \mathrm{OH}+\mathrm{CH}_{3} \mathrm{SCH}_{3} \rightarrow \mathrm{CH}_{3} \mathrm{SCH}_{2}+\mathrm{H}_{2} \mathrm{O} \\
& \mathrm{OH}+\mathrm{CH}_{3} \mathrm{SCH}_{3}+\mathrm{M} \leftrightarrow \mathrm{CH}_{3} \mathrm{~S}(\mathrm{OH}) \mathrm{CH}_{3}+\mathrm{M} .
\end{aligned}
$$

At $298 \mathrm{~K}$ and $1 \mathrm{~atm}$ Reaction (R4) is predominant but Reaction (R5) becomes more important as temperature decreases. The first channel (Reaction R4) can be modeled directly following Atkinson et al. (2004). In Reaction (R5) the $\mathrm{OH}$ adduct itself may decompose back to its original reactants or it can react with $\mathrm{O}_{2}$ to form DMSO $\left[\mathrm{CH}_{3} \mathrm{~S}(\mathrm{O}) \mathrm{CH}_{3}\right]$ :

$\mathrm{CH}_{3} \mathrm{~S}(\mathrm{OH}) \mathrm{CH}_{3}+\mathrm{O}_{2} \rightarrow \mathrm{CH}_{3} \mathrm{~S}(\mathrm{O}) \mathrm{CH}_{3}+\mathrm{HO}_{2}$.

The chain of reactions that begins with Reaction (R5) and the formation of the $\mathrm{OH}$ adduct can be treated following Zhu et al. (2006):

$\mathrm{DMS}+\mathrm{OH}+\mathrm{O}_{2} \rightarrow 0.5 \mathrm{DMSO}+0.2 \mathrm{DMSO} 2+0.3 \mathrm{MSIA}$.(R7)

Another DMS oxidation pathway is DMS+O which yields $\mathrm{CH}_{3} \mathrm{SO}$ and a methyl radical (Atkinson et al., 2004). The reaction of DMS $+\mathrm{NO}_{3}$ may be important at night and yields $\mathrm{CH}_{3} \mathrm{SCH}_{2}$ and nitric acid.

Table 3 lists the subset of $S_{\text {org }}$ reactions described here including oxidation reactions of DMS. Compromises and assumptions are necessary to treat some of the reactions and/or byproducts due to incomplete knowledge and the various assumptions are explained. Reactions involving halogen species other than chlorine are problematic to treat at this time because of uncertainties about their emissions.

$\mathrm{CH}_{3} \mathrm{SCH}_{2}$ (MSCH2) Reactions: this radical is formed by three of the five DMS reactions. Its primary reaction pathways are with $\mathrm{O}_{2}$ and $\mathrm{NO}_{3}$. The reaction with $\mathrm{O}_{2}$ is

$$
\mathrm{CH}_{3} \mathrm{SCH}_{2}+\mathrm{O}_{2}+\mathrm{M} \rightarrow \mathrm{CH}_{3} \mathrm{SCH}_{2} \mathrm{OO}+\mathrm{M}
$$

and the peroxyl radical $\mathrm{CH}_{3} \mathrm{SCH}_{2} \mathrm{OO}$ is subsequently denoted MSP. Products of MSCH2 $+\mathrm{NO}_{3}$ are not known and are assumed, analogous to the companion reaction with $\mathrm{O}_{2}$, to be MSP and NO.

MSP Reactions: this mechanism includes three reactions involving MSP as a reactant. One is the reaction of MSP with itself. The other two are MSP with NO and MSP with $\mathrm{HO}_{2}$. MSP reactions with itself and other species are believed to form $\mathrm{CH}_{3} \mathrm{SCH}_{2} \mathrm{O}$ which is very unstable and rapidly decomposes to $\mathrm{CH}_{3} \mathrm{~S}$ and $\mathrm{HCHO}$. Thus, all reactions involving MSP can be treated as yielding products $\mathrm{CH}_{3} \mathrm{~S}, \mathrm{HCHO}$ and, in the case of $\mathrm{MSP}+\mathrm{NO}, \mathrm{NO}_{2}$.

$\mathrm{CH}_{3} \mathrm{~S}$ Reactions: Finlayson-Pitts and Pitts (2000) report that the fate of $\mathrm{CH}_{3} \mathrm{~S}$ in the atmosphere is unclear. This is because there is evidence that it reacts with many different species in a variety of ways and in most cases the products are not well known. For example, $\mathrm{CH}_{3} \mathrm{~S}+\mathrm{O}_{2}$ produces $\mathrm{CH}_{3} \mathrm{SOO}$, but the latter has a short lifetime because it decomposes back to $\mathrm{CH}_{3} \mathrm{~S}$. Reaction with $\mathrm{NO}_{2}$ produces $\mathrm{CH}_{3} \mathrm{SO}+\mathrm{NO} . \mathrm{CH}_{3} \mathrm{~S}+\mathrm{O}_{3}$ is another likely reaction but a large number of potential reaction channels exist. These include yields of $\mathrm{CH}_{3} \mathrm{SO}+\mathrm{O}_{2}$ (the yield is low at low pressure while data at high pressure are nonexistent), $\mathrm{CH}_{3}+\mathrm{SO}+\mathrm{O}_{2}, \mathrm{CH}_{2} \mathrm{SO}+\mathrm{H}+\mathrm{O}_{2}, \mathrm{CH}_{2} \mathrm{SO}+\mathrm{HO}_{2}$, $\mathrm{CH}_{2} \mathrm{~S}+\mathrm{OH}+\mathrm{O}_{2}$, and $\mathrm{CH}_{3} \mathrm{O}+\mathrm{SO}_{2}$. The percent yields of many of these channels are estimated to be very small and species like $\mathrm{CH}_{2} \mathrm{SO}$ and $\mathrm{CH}_{2} \mathrm{~S}$ are very short-lived. Consequently, Zhu et al. (2006) aggregated several reactions into a 
Table 3. Reactions added to CB05 for organic sulfur species and their reaction products ${ }^{\mathrm{a}}$.

\begin{tabular}{|c|c|c|c|}
\hline Reactants & Products & $\begin{array}{l}\text { Rate Constant } \\
\left(\mathrm{cm}^{3} \text { molecule }^{-1} \mathrm{~s}^{-1}\right)^{\mathrm{b}}\end{array}$ & Reference \\
\hline $\mathrm{DMS}+\mathrm{O}$ & $\mathrm{MSO}+\mathrm{CH}_{3}$ & $1.34 \times 10^{-11} \exp (409 / T)$ & Atkinson et al. (2004) \\
\hline $\mathrm{DMS}+\mathrm{NO}_{3}$ & $\mathrm{MSCH}_{2}+\mathrm{HNO}_{3}$ & $1.9 \times 10^{-13} \exp (520 / T)$ & Atkinson et al. (2004) \\
\hline $\mathrm{DMS}+\mathrm{OH}$ & $\mathrm{MSCH}_{2}+\mathrm{H}_{2} \mathrm{O}$ & $1.1 \times 10^{-11} \exp (-253 / T)$ & Atkinson et al. (2004) \\
\hline $\mathrm{DMS}+\mathrm{OH}+\mathrm{O}_{2}$ & $\begin{array}{l}0.5 \text { DMSO + } 0.2 \text { DMSO2 } \\
+0.3 \text { MSIA }\end{array}$ & $\begin{array}{l}\left\{1 \times 10^{-39} \exp (5820 / T)\left[\mathrm{O}_{2}\right]\right\} / \\
\left\{1+5 \times 10^{-30} \exp (6280 / T)\left[\mathrm{O}_{2}\right]\right\}\end{array}$ & Zhu et al. (2006) \\
\hline $\mathrm{DMS}+\mathrm{Cl}$ & $\mathrm{MSCH}_{2}+\mathrm{HCl}$ & $3.3 \times 10^{-10}$ & Atkinson et al. (2004) \\
\hline $\mathrm{MSCH}_{2}+\mathrm{O}_{2}+\mathrm{M}$ & $\mathrm{MSP}+\mathrm{M}$ & $5.7 \times 10^{-12}$ & $\begin{array}{l}\text { Finlayson-Pitts and Pitts } \\
\text { (2000); Atkinson et al. (2004) }\end{array}$ \\
\hline $\mathrm{MSCH}_{2}+\mathrm{NO}_{3}$ & $\mathrm{MSP}+\mathrm{NO}$ & $3.0 \times 10^{-10}$ & NASA, 1997 \\
\hline $\mathrm{MSP}+\mathrm{NO}$ & $\mathrm{CH}_{3} \mathrm{~S}+\mathrm{HCHO}+\mathrm{NO}_{2}$ & $4.9 \times 10^{-12} \exp (260 / T)$ & $\begin{array}{l}\text { Atkinson et al. (2004); Zhu et } \\
\text { al. (2006) }\end{array}$ \\
\hline MSP + MSP & $2 \mathrm{CH}_{3} \mathrm{~S}+2 \mathrm{HCHO}+\mathrm{O}_{2}$ & $1.0 \times 10^{-11}$ & $\begin{array}{l}\text { Atkinson et al. (2004); Zhu et } \\
\text { al. (2006) }\end{array}$ \\
\hline $\mathrm{MSP}+\mathrm{HO}_{2}$ & $\mathrm{CH}_{3} \mathrm{~S}+\mathrm{HCHO}+\mathrm{OH}+\mathrm{O}_{2}$ & $3.8 \times 10^{-13} \exp (780 / T)$ & $\begin{array}{l}\text { Zhu et al. (2006) following } \\
\text { Tyndall et al. (2001) }\end{array}$ \\
\hline $\mathrm{CH}_{3} \mathrm{~S}+\mathrm{O}_{3}$ & $\begin{array}{l}0.9 \mathrm{SO}_{2}+0.1 \mathrm{H}_{2} \mathrm{SO}_{4} \\
0.9 \mathrm{CH}_{3} \mathrm{O}+0.1 \mathrm{CH}_{3}^{\mathrm{c}}\end{array}$ & $1.15 \times 10^{-12} \exp (430 / T)^{\mathrm{d}}$ & $\begin{array}{l}\text { Atkinson et al. (2004); Zhu et } \\
\text { al. (2006) }\end{array}$ \\
\hline $\mathrm{CH}_{3} \mathrm{~S}+\mathrm{NO}_{2}$ & $\mathrm{MSO}+\mathrm{NO}$ & $3.0 \times 10^{-11} \exp (210 / T)$ & Atkinson et al. (2004) \\
\hline $\mathrm{MSO}+\mathrm{O}_{3}$ & $\begin{array}{l}0.14 \mathrm{CH}_{3} \mathrm{~S}+0.86 \mathrm{CH}_{3} \\
+0.86 \mathrm{SO}_{2}+\mathrm{O}_{2}\end{array}$ & $6.0 \times 10^{-13}$ & $\begin{array}{l}\text { Finlayson-Pitts and Pitts } \\
\text { (2000); Atkinson et al. (2004) }\end{array}$ \\
\hline $\mathrm{MSO}+\mathrm{NO}_{2}$ & $\mathrm{CH}_{3}+\mathrm{SO}_{2}+\mathrm{NO}$ & $1.2 \times 10^{-11}$ & $\begin{array}{l}\text { Finlayson-Pitts and Pitts } \\
\text { (2000); Atkinson et al. (2004) }\end{array}$ \\
\hline $\mathrm{DMSO}+\mathrm{OH}$ & 0.9 MSIA + 0.1 DMSO2 & $9.0 \times 10^{-11}$ & $\begin{array}{l}\text { Kukui et al. (2003); Zhu et } \\
\text { al. (2006) }\end{array}$ \\
\hline $\mathrm{MSIA}+\mathrm{OH}$ & $0.9 \mathrm{SO}_{2}+0.1 \mathrm{MSA}$ & $9.0 \times 10^{-11}$ & $\begin{array}{l}\text { Kukui et al. (2003); Zhu et } \\
\text { al. (2006) }\end{array}$ \\
\hline $\mathrm{CH}_{3}+\mathrm{O}_{3}$ & $\mathrm{CH}_{3} \mathrm{O}+\mathrm{O}_{2}$ & $4.7 \times 10^{-12} \exp (-210 / T)$ & Atkinson et al. (2006) \\
\hline $\mathrm{CH}_{3}+\mathrm{O}$ & $\mathrm{HCHO}+\mathrm{H}$ & $1.3 \times 10^{-10}$ & Atkinson et al. (2006) \\
\hline $\mathrm{CH}_{3} \mathrm{O}+\mathrm{O}_{2}$ & $\mathrm{HCHO}+\mathrm{HO}_{2}$ & $7.2 \times 10^{-14} \exp (-1080 / T)$ & Atkinson et al. (2006) \\
\hline $\mathrm{CH}_{3} \mathrm{O}+\mathrm{NO}_{2}$ & $\mathrm{HCHO}+\mathrm{HONO}$ & $9.6 \times 10^{-12} \exp (-1150 / T)$ & Atkinson et al. (2006) \\
\hline
\end{tabular}

a Abbreviations: DMS = dimethylsulfide, $\mathrm{CH}_{3} \mathrm{SCH}_{3} ; \mathrm{DMSO}=$ dimethylsulfoxide, $\mathrm{CH}_{3} \mathrm{~S}(\mathrm{O}) \mathrm{CH}_{3} ;$ DMSO2 = dimethylsulfone, $\mathrm{CH}_{3} \mathrm{~S}(\mathrm{O})(\mathrm{O}) \mathrm{CH}_{3} ; \mathrm{MSCH} 2=$ methylthiomethyl radical, $\mathrm{CH}_{3} \mathrm{SCH}_{2} ; \quad \mathrm{MSP}=$ methylthiomethylperoxyl radical, $\mathrm{CH}_{3} \mathrm{SCH}_{2} \mathrm{OO} ; \mathrm{MSO}=$ methylsulfoxide radical, $\mathrm{CH}_{3} \mathrm{SO} ; \mathrm{MSIA}=$ methanesulfinic acid, $\mathrm{CH}_{3} \mathrm{SOOH}$; MSA = methanesulfonic acid, $\mathrm{CH}_{3} \mathrm{~S}(\mathrm{O})(\mathrm{O}) \mathrm{OH}$

$\mathrm{b}$ The exception is for termolecular rate constants that have units of $\mathrm{cm}^{6}$ molecule ${ }^{-2} \mathrm{~s}^{-1}$.

${ }^{c}$ The mechanism of Zhu et al. (2006) treats the reaction of $\mathrm{CH}_{3} \mathrm{~S}$ with a variety of species as one reaction producing sulfur dioxide and sulfuric acid with no additional products specified. As implemented in CMAQ, the additional products are assumed to be species needed to achieve stoichiometric closure to the reaction in the presence of $\mathrm{H}_{2} \mathrm{O}$.

${ }^{d}$ This is believed to be a termolecular reaction (Atkinson et al., 2004) but the rate constant at different pressures has not been determined. See the text for further discussion.

single net reaction for $\mathrm{CH}_{3} \mathrm{~S}$ with a host of ambient species as follows:

$\mathrm{CH}_{3} \mathrm{~S} \stackrel{\mathrm{NO}_{2}, \mathrm{O}_{2}, \mathrm{HO}_{2}, \mathrm{O}_{3}, \mathrm{H}_{2} \mathrm{O}}{\longrightarrow} 0.9 \mathrm{SO}_{2}+0.1 \mathrm{H}_{2} \mathrm{SO}_{4}$

In addition, they assigned this a rate constant of $5.0 \mathrm{~cm}^{3}$ molecule $\mathrm{s}^{-1} \mathrm{~s}^{-1}$ assuring a near instantaneous reaction. In light of data in Atkinson et al. (2004), and given the thermal instability of the $\mathrm{CH}_{3} \mathrm{SOO}$ product, we choose to ignore the reaction of $\mathrm{CH}_{3} \mathrm{~S}$ with $\mathrm{O}_{2}$. The reaction $\mathrm{CH}_{3} \mathrm{~S}+\mathrm{NO}$ produces $\mathrm{CH}_{3} \mathrm{SNO}$, but it was not included here because it photodissociates back to $\mathrm{CH}_{3} \mathrm{~S}$ and $\mathrm{NO}$ during daytime resulting in a fairly short lifetime and limited presence in the atmosphere. Clearly, this is one area where future advances may require significant revision to the mechanism. The reaction with $\mathrm{O}_{3}$ follows the net yield modeled in $\mathrm{Zhu}$ et al. (2006), but applies the measured rate constant in Atkinson et al. (2004).

MSO Reactions: $\mathrm{MSO}+\mathrm{O}_{3}$ has been observed to yield a variety of products. One, $\mathrm{CH}_{2} \mathrm{SO}_{2}$, is a relative enigma because neither NASA (1997), Finlayson-Pitts and Pitts (2000) nor Atkinson et al. (2004) provide any information on its reactivity or fate. Two remaining noteworthy reaction channels 
- yielding $\mathrm{CH}_{3} \mathrm{~S}$ and $\mathrm{CH}_{3}+\mathrm{SO}_{2}$ (Table 3) - have partial yields that may be modeled based on data cited by FinlaysonPitts and Pitts (2000). Finally, $\mathrm{MSO}+\mathrm{NO}_{2}$ is well characterized and relatively fast.

DMSO \& MSIA Reactions: DMSO reacts rapidly with $\mathrm{O}_{2}$ to form DMSO2 (Table 3). Zhu et al. (2006) relied on data from Kukui et al. (2003) to model the reactions of DMSO and MSIA with $\mathrm{OH}$. Their simplifications reduce a complex set of reactions into two simplified reactions that were adopted in this study $\left(k=9.0 \times 10^{-11} \mathrm{~cm}^{3}\right.$ molecule ${ }^{-1} \mathrm{~s}^{-1}$ for both):

$\mathrm{DMSO}+\mathrm{OH} \rightarrow 0.9 \mathrm{MSIA}+0.1 \mathrm{DMSO} 2$

$\mathrm{MSIA}+\mathrm{OH} \rightarrow 0.9 \mathrm{SO}_{2}+0.1 \mathrm{MSA}$

The net effect of the organic sulfur reaction set that starts with DMS is the production of inorganic species $\mathrm{SO}_{2}$ and $\mathrm{H}_{2} \mathrm{SO}_{4}$, along with organic species DMSO, DMSO2, MSIA and MSA. A number of reactions involving DMS, DMSO, DMSO2 and MSIA occur in clouds.

$\mathrm{CH}_{3}$ and $\mathrm{CH}_{3} \mathrm{O}$ Reactions: reactions involving the radicals $\mathrm{CH}_{3}$ and $\mathrm{CH}_{3} \mathrm{O}$ (produced from reactions previously described) are mentioned here for completeness. The chemistry of these species is well characterized. $\mathrm{CH}_{3}$ reacts fairly quickly with $\mathrm{O}$ and $\mathrm{O}_{3}$ to produce $\mathrm{CH}_{3} \mathrm{O} . \mathrm{CH}_{3} \mathrm{O}$ reacts with $\mathrm{O}_{2}$ to produce $\mathrm{HCHO}$ and $\mathrm{HO}_{2}$, and with $\mathrm{NO}_{2}$ to yield $\mathrm{HCHO}$ and HONO.

Heterogeneous (Cloud) Chemistry: in their ADOM model, Karamchandani and Venkatram (1992) used a heterogeneous chemistry approach similar into that in RADM/CMAQ although their treatment of cloud microphysics was more sophisticated. A cloud model developed by de Valk and van der Hage (1994) for use in long range transport models also used relatively sophisticated cloud microphysics but its chemistry only treated the oxidation reactions of S(IV) by $\mathrm{O}_{3}$ and $\mathrm{H}_{2} \mathrm{O}_{2}$. Möller and Mauersberger (1992) examined cloud chemistry from the opposite perspective, using sophisticated heterogeneous chemistry (57 aqueous reactions and equilibria) in a flow-through reactor-type model to examine the roles of various inorganic and organic reactants in sulfur oxidation and radical cycling. Their sulfur chemistry included $\mathrm{S}\left(\mathrm{IV}\right.$ ) oxidation by $\mathrm{O}_{3}, \mathrm{H}_{2} \mathrm{O}_{2}$, organic peroxides, $\mathrm{OH}$, $\mathrm{NO}_{3}$ and metal ion catalysis, but no organic sulfur reactions. In addition, they simulated the interplay between $\mathrm{OH}, \mathrm{H}_{2} \mathrm{O}_{2}$, $\mathrm{HO}_{2}, \mathrm{O}_{3}, \mathrm{NO}_{3}$ and soluble organic species in cloud droplets. Under certain conditions (especially low $\mathrm{SO}_{2}$ ), clouds can be a net source of $\mathrm{HO}_{2}$ which can be transferred into the gas phase from the droplets. At very low $\mathrm{SO}_{2}(<0.1 \mathrm{ppbV})$ no net $\mathrm{H}_{2} \mathrm{O}_{2}$ destruction (because of in-cloud $\mathrm{H}_{2} \mathrm{O}_{2}$ formation) was computed, although clouds become a very effective sink for $\mathrm{H}_{2} \mathrm{O}_{2}$ when $\mathrm{SO}_{2}>0.5 \mathrm{ppbV}$. Möller and Mauersberger (1992) concluded that, in low $\mathrm{SO}_{2}$ conditions, clouds play an important role in photooxidant dynamics.
Williams et al. (2002) used a one-dimensional cloud model to investigate the role of marine stratocumulus clouds as a possible source of HONO. Their calculations, based on a cloud model originated by Van den Berg et al. (2000), simulated aqueous chemistry following the CAPRAM reaction mechanism (Herrmann et al., 2000) involving 86 species and 178 reactions. Williams et al. (2002) added 26 reactions treating reactive halogen species but simplified other reactions involving peroxy radicals. Their results indicated that in-cloud HONO formation, and its effects on droplet acidity and ozone chemistry, is most likely to be important in a moderately-polluted marine environment. However, due to large uncertainties in the aqueous chemistry involved, the modest impact on photochemistry and the high computational requirements of the modified mechanism, they recommended against trying to incorporate $\mathrm{HNO}_{4} / \mathrm{HONO}$ chemistry into larger-scale three-dimensional atmospheric chemistry models. Global modeling of sulfate and nitrate aerosols by Park et al. (2004) using their GEOS-Chem model computed in-cloud $\mathrm{SO}_{2}$ oxidation by $\mathrm{O}_{3}$ and $\mathrm{H}_{2} \mathrm{O}_{2}$ at an assumed droplet $\mathrm{pH}$ of 4.5. They computed gas phase oxidation of DMS with yields of MSA and $\mathrm{SO}_{2}$ but did not include DMS or MSA in the heterogeneous reactions.

Henze and Seinfeld (2006) reported increases in secondary organic aerosol (SOA) formation from isoprene when using a parameterized aerosol formation mechanism in GEOS-Chem. Recently, Ervens et al. (2008) examined the formation of SOA by way of heterogeneous reactions involving organic compounds derived from isoprene. Two processes were modeled for producing aerosol mass from isoprene oxidation products by partitioning semivolatile organics between the gas and condensed phases using empirical partitioning ratios and modeling heterogeneous chemical reactions involving water-soluble isoprene oxidation products. The carbon aerosol yield was significant (to greater than $10 \%$ on the initial isoprene carbon mass in boundary layer cycling through clouds) and was dependent on the $\mathrm{VOC} / \mathrm{NO}_{\mathrm{x}}$ ratio. Their heterogeneous chemistry model included over 40 reactions to simulate the evolution of inorganic sulfur and organic reactants that leads to sulfate and water soluble SOA products. The release of CMAQ version 4.7 (denoted "CMAQ4.7") includes an update to the cloud chemistry that incorporates in-cloud SOA formation pathways originating with glyoxal and methylglyoxal (http://www.cmascenter.org/help/documentation. $\mathrm{cfm}$ ?MODEL=cmaq $\backslash \&$ VERSION=4.7\\&temp_id=99999). Thus, there is a need to follow up this current effort based on CMAQ4.6 by selectively adding organic reactions that produce SOA.

Early work performed under the National Acid Precipitation Assessment Program (NAPAP) of the 1980s (NAPAP, 1991) produced a simple cloud chemistry modeling approach within the larger RADM atmospheric chemistry model. The RADM module treated 5 reactions involving $\mathrm{SO}_{2}$ oxidation by $\mathrm{H}_{2} \mathrm{O}_{2}, \mathrm{~S}(\mathrm{IV})\left(=\mathrm{SO}_{2}\right.$ (aq) $+\mathrm{HSO}_{3}^{-}+\mathrm{SO}_{3}^{2-}$ ) oxidation by $\mathrm{O}_{3}$, 
$\mathrm{HSO}_{3}^{-}$oxidation by peroxyacetic acid (PAA) and methylhydrogen peroxide (MHP), and S(IV) catalytic oxidation by $\mathrm{Fe}^{2+}$ and $\mathrm{Mn}^{2+}$. This approach was adapted as the default CMAQ cloud chemistry module (CCM). It assumes steadystate in-cloud conditions during the time integration of the kinetic equations, with gas-aqueous equilibria computed using Henry's Law constants for $\mathrm{SO}_{2}, \mathrm{H}_{2} \mathrm{SO}_{4}, \mathrm{CO}_{2}, \mathrm{NH}_{3}, \mathrm{HNO}_{3}$, $\mathrm{O}_{3}, \mathrm{H}_{2} \mathrm{CO}_{2}$ (formic acid), $\mathrm{H}_{2} \mathrm{O}_{2}, \mathrm{HCl}$, PAA, and MHP.

Following the approach of Zhu (2004) and Zhu et al. (2006), it is clear that there are a number of aqueousphase chemical reactions involving DMS and its derivatives that lead to sulfate aerosol formation and should be added to complement the gas-phase reactions involving $S_{\text {org }}$. The most important of these are:

$\mathrm{DMS}_{(\mathrm{aq})}+\mathrm{O}_{3(\mathrm{aq})} \rightarrow \mathrm{DMSO}_{(\mathrm{aq})}+$ products

$\mathrm{DMS}_{(\mathrm{aq})}+\mathrm{OH}_{(\mathrm{aq})} \rightarrow \mathrm{DMSO}_{(\mathrm{aq})}+$ products.

The principal aqueous reactions of DMSO are

$$
\begin{aligned}
& \operatorname{DMSO}_{(\mathrm{aq})}+\mathrm{OH}_{(\mathrm{aq})} \rightarrow \mathrm{MSIA}_{(\mathrm{aq})}+\mathrm{CH}_{3(\mathrm{aq})} \\
& \mathrm{DMSO}_{(\mathrm{aq})}+\mathrm{SO}_{4(\mathrm{aq})}^{-} \rightarrow \mathrm{CH}_{3} \mathrm{SO}_{2(\mathrm{aq})}^{-}+\mathrm{SO}_{4(\mathrm{aq})}^{2-}+2 \mathrm{H}_{(\mathrm{aq})}^{+} .
\end{aligned}
$$

Details of these and other aqueous reactions are listed in Table 4. Reactions involving DMSO, DMSO2, MSIA, MSA and related species are also known to produce sulfate.

The most likely source of $\mathrm{Cl}$ and $\mathrm{Cl}_{2}^{-}$in cloud droplets is not from gas phase $\mathrm{Cl}$ - which is highly reactive and only expected to exist in air at extremely low concentrations - but $\mathrm{HCl}$. The latter goes readily into solution where it dissociates as $\mathrm{HCl} \rightarrow \mathrm{H}^{+}+\mathrm{Cl}^{-}$. In the presence of the sulfate radical,

$\mathrm{SO}_{4(\mathrm{aq})}^{-}+\mathrm{Cl}_{(\mathrm{aq})}^{-} \rightarrow \mathrm{SO}_{4(\mathrm{aq})}^{2-}+\mathrm{Cl}_{(\mathrm{aq})}$

(Zhu, 2004) and $\left[\mathrm{Cl}_{\mathrm{aq}}\right.$ reacts with $\left[\mathrm{Cl}^{-}\right]_{\mathrm{aq}}$ to produce $\left[\mathrm{Cl}_{2}^{-}\right]_{\mathrm{aq}}$. Properties of $\mathrm{SO}_{4}^{-}$have been measured in the laboratory (Chawla and Fessenden, 1975; Huie and Clifton, 1990), and its role in heterogeneous chemistry is described later. Also important are the aqueous reactions

$$
\begin{aligned}
& \mathrm{OH}_{(\mathrm{aq})}+\mathrm{Cl}_{(\mathrm{aq})}^{-} \rightarrow \mathrm{HOCl}_{(\mathrm{aq})}^{-} \\
& \mathrm{HOCl}_{(\mathrm{aq})}^{-}+\mathrm{H}_{(\mathrm{aq})}^{+} \rightarrow \mathrm{Cl}_{(\mathrm{aq})}+\mathrm{H}_{2} \mathrm{O} .
\end{aligned}
$$

Thus, $[\mathrm{Cl}]_{\mathrm{aq}}$ is affected by $\left[\mathrm{SO}_{4}^{-}\right]_{\mathrm{aq}}$ and $\left[\mathrm{Cl}^{-}\right]_{\mathrm{aq}}$. $\mathrm{Zhu}(2004)$ set $\left[\mathrm{SO}_{4}^{-}\right]_{\mathrm{aq}},[\mathrm{Cl}]_{\mathrm{aq}}$ and $\left[\mathrm{Cl}_{2}^{-}\right]_{\mathrm{aq}}$ to constant values in his model. Chlorine's role in the heterogeneous chemistry of sulfate formation depends on the presence of the chloride ion and Zhu (2004) used the equilibrium relation

$$
\frac{[\mathrm{Cl}]_{(\mathrm{aq})}\left[\mathrm{Cl}^{-}\right]_{(\mathrm{aq})}}{\left[\mathrm{Cl}_{2}^{-}\right]_{(\mathrm{aq})}}=7.14 \times 10^{-6} \mathrm{M}
$$

to compute the balance between $\mathrm{Cl}, \mathrm{Cl}^{-}$and $\mathrm{Cl}_{2}^{-}$in droplets. Of the five DMSO oxidation reactions, those involving reactions with $\left[\mathrm{Cl}_{\mathrm{aq}}\right.$ and $\left[\mathrm{Cl}_{2}^{-}\right]_{\mathrm{aq}}$ are 2 to 4 orders of magnitude slower than those in which $[\mathrm{OH}]_{\mathrm{aq}}$ and $\left[\mathrm{SO}_{4}^{-}\right]_{\mathrm{aq}}$ are reactants. Chlorine as $\mathrm{Cl}_{2}^{-}$can play a larger - though not dominant role in reactions involving $\mathrm{CH}_{3} \mathrm{SO}_{2}^{-}$. Hence, the role of chlorine in heterogeneous organic sulfur chemistry is of minor importance most of the time.

The reaction of DMS with $\mathrm{OH}$ (Reaction R13) is more than a factor of 20 faster than DMS with $\mathrm{O}_{3}$ (Reaction R12) but $\mathrm{O}_{3}$ concentrations are far greater than $\mathrm{OH}$ making the ozone reaction the dominant pathway. For reactions with DMSO, the hierarchy of rate constants is $k_{\mathrm{OH}} \approx k_{\mathrm{Cl}}>$ $k_{\mathrm{SO}_{4}^{-}} \gg k_{\mathrm{Cl}_{2}^{-}} \gg k_{\mathrm{O}_{3}}$. Ozone is the most abundant reactant to attack DMSO by at least 2 to 3 orders of magnitude. Nevertheless, the benefit of a higher concentration is still not sufficient to make up for its lower rate constant and the $\mathrm{OH}$ and $\mathrm{SO}_{4}^{-}$reactions with DMSO will usually be the most important.

It is clear from the work cited here that there are natural emissions not treated in the standard SMOKE/CMAQ modeling package that are considered important on regional and global scales. Most notably, these omissions involve reduced sulfur (especially DMS), $\mathrm{NH}_{3}$ and water-soluble chlorine species from oceans, and $\mathrm{LNO}_{\mathrm{x}}$. Despite the inherent uncertainty in quantifying these emissions, it is imperative to include them in any effort to examine a more complete picture of how natural emissions influence air quality. Smith and Mueller (2010) describe in detail the methodologies used to add natural emissions to the standard SMOKE/CMAQ inventory. Data from the National Lightning Detection Network along with recent work estimating $\mathrm{NO}_{\mathrm{x}}$ production from lightning strokes formed the basis of $\mathrm{LNO}_{\mathrm{x}}$ emission estimates. Ammonia emissions from populations of large wild animals were included using estimates from US and Canadian wildlife inventories and emissions estimates for Mexico in the GEIA data base. Atmospheric chlorine is believed to play a role in ozone formation in coastal areas (Knipping and Dabdub, 2003) and provides radicals that may also contribute to aerosol formation in clouds. Effective emissions rates for $\mathrm{HCl}$ and nitryl chloride $\left(\mathrm{ClNO}_{2}\right)$ in the marine boundary layer were incorporated from the GEIA data base, as were ammonia emissions from the oceans.

This paper describes modifications in the CMAQ Model required so that it can fully use the natural emissions data developed by Smith and Mueller (2010). CMAQ is a widely used tool for estimating the association between pollutant emissions and ambient concentrations. The version of CMAQ applied in this study (i.e., CMAQ4.6) lacked reactions involving certain chemical species known to be important in natural systems. For example, the standard CMAQ configuration does not treat halogen species and the reduced sulfur compounds often associated with natural sources. This paper describes CMAQ changes needed to incorporate chemical reactions for organic sulfur compounds, hydrogen sulfide, chlorine compounds, and associated reaction products in both the gas and aqueous (cloud) 
Table 4. Revised set of heterogeneous cloud reactions in CMAQ4.6. ${ }^{\mathrm{a}}$.

\begin{tabular}{|c|c|}
\hline Reaction $^{\mathrm{b}}$ & $\begin{array}{l}\text { Rate Constant, } k \\
\left(\mathrm{M}^{-1} \mathrm{~s}^{-1}\right)\end{array}$ \\
\hline $\mathrm{DMS}+\mathrm{O}_{3} \rightarrow \mathrm{DMSO}+\mathrm{O}_{2}$ & $5.3 \times 10^{12} \exp (-2600 / T)^{\mathrm{c}}$ \\
\hline $\mathrm{DMS}+\mathrm{OH} \rightarrow \mathrm{DMSO}+\mathrm{HO}_{2}$ & $1.9 \times 10^{10^{\mathrm{d}}}$ \\
\hline $\mathrm{DMSO}+\mathrm{O}_{3} \rightarrow \mathrm{DMSO} 2+\mathrm{O}_{2}$ & $5.7 \times 10^{0^{\mathrm{e}}}$ \\
\hline $\mathrm{DMSO}+\mathrm{OH} \rightarrow \mathrm{MSIA}+\mathrm{CH}_{3}$ & $4.7 \times 10^{11} \exp (-1270 / T)^{\mathrm{f}}$ \\
\hline $\mathrm{DMSO}+\mathrm{SO}_{4}^{-} \rightarrow \mathrm{CH}_{3} \mathrm{SO}_{2}^{-}+\mathrm{SO}_{4}^{2-}+2 \mathrm{H}^{+}$ & $3.7 \times 10^{11} \exp (-1440 / T)^{\mathrm{f}}$ \\
\hline $\mathrm{DMSO}+\mathrm{Cl} \rightarrow \mathrm{CH}_{3} \mathrm{SO}_{2}^{-}+2 \mathrm{H}^{+}+\mathrm{Cl}^{-}$ & $6.3 \times 10^{9^{f}}$ \\
\hline $\mathrm{DMSO}+\mathrm{Cl}_{2}^{-} \rightarrow \mathrm{CH}_{3} \mathrm{SO}_{2}^{-}+\mathrm{Cl}_{2}$ & $1.7 \times 10^{7^{f}}$ \\
\hline $\mathrm{DMSO} 2+\mathrm{OH} \rightarrow 0.3 \mathrm{MSA}+0.7 \mathrm{SO}_{4}^{2-}+1.4 \mathrm{H}^{+}$ & $5.1 \times 10^{9} \exp (-1690 / T)^{\mathrm{f}}$ \\
\hline $\mathrm{CH}_{3} \mathrm{SO}_{2}^{-}+\mathrm{OH} \rightarrow \mathrm{CH}_{3} \mathrm{SO}_{3}^{-}+\mathrm{H}^{+}+\mathrm{O}_{2}^{-}$ & $7.7 \times 10^{9^{\mathrm{f}}}$ \\
\hline $\mathrm{CH}_{3} \mathrm{SO}_{2}^{-}+\mathrm{SO}_{4}^{-} \rightarrow \mathrm{CH}_{3} \mathrm{SO}_{3}^{-}+\mathrm{SO}_{4}^{2-}+\mathrm{H}^{+}$ & $1.0 \times 10^{9^{\mathrm{f}}}$ \\
\hline $\mathrm{CH}_{3} \mathrm{SO}_{2}^{-}+\mathrm{Cl}_{2}^{-} \rightarrow \mathrm{CH}_{3} \mathrm{SO}_{3}^{-}+2 \mathrm{Cl}^{-}+\mathrm{H}^{+}$ & $8.0 \times 10^{8^{f}}$ \\
\hline $\mathrm{CH}_{3} \mathrm{SO}_{3}^{-}+\mathrm{OH} \rightarrow \mathrm{SO}_{4}^{2-}+\mathrm{H}^{+}$ & $8.8 \times 10^{10} \exp (-2630 / T)^{\mathrm{f}}$ \\
\hline $\mathrm{SO}_{2}+\mathrm{O}_{3} \rightarrow \mathrm{SO}_{4}^{2-}+2 \mathrm{H}^{+}$ & $2.4 \times 10^{4^{\mathrm{g}}}$ \\
\hline $\mathrm{HSO}_{3}^{-}+\mathrm{O}_{3} \rightarrow \mathrm{SO}_{4}^{2-}+\mathrm{H}^{+}$ & $3.5 \times 10^{5} \exp [-5530(1 / T-1 / 298)]^{\mathrm{h}}$ \\
\hline $\mathrm{SO}_{3}^{2-}+\mathrm{O}_{3} \rightarrow \mathrm{SO}_{4}^{2-}$ & $1.5 \times 10^{9} \exp [-5280(1 / T-1 / 298)]^{\mathrm{h}}$ \\
\hline $\mathrm{HSO}_{3}^{-}+\mathrm{H}_{2} \mathrm{O}_{2} \rightarrow \mathrm{SO}_{4}^{2-}+\mathrm{H}^{+}$ & $\frac{7.45 \times 10^{7} \exp [-4430(1 / T-1 / 298)]}{1+13\left[\mathrm{H}^{+}\right]}$ \\
\hline $\mathrm{HSO}_{3}^{-}+\mathrm{MHP} \rightarrow \mathrm{SO}_{4}^{2-}+\mathrm{H}^{+}$ & $1.75 \times 10^{7} \exp [-3801(1 / T-1 / 298)]$ \\
\hline $\mathrm{HSO}_{3}^{-}+\mathrm{PAA} \rightarrow \mathrm{SO}_{4}^{2-}+\mathrm{H}^{+}$ & $3.64 \times 10^{7}\left\{\left[\mathrm{H}^{+}\right]+1.65 \times 10^{-5}\right\} \exp [-3994(1 / T-1 / 298)$ \\
\hline
\end{tabular}

a CMAQ species abbreviations: $\mathrm{MHP}=$ methylhydrogen peroxide; $\mathrm{PAA}=$ peroxyacetyl acid.

$\mathrm{b}$ The last six reactions are essentially those treated in the standard version of CMAQ, although their rate constants were taken from other sources except for the last two which are the expressions for $k$ used in CMAQ.

${ }^{\mathrm{c}}$ Zhu (2004), Zhu et al. (2006), Gershenzon et al. (2001).

${ }^{d}$ Zhu (2004), Zhu et al. (2006), Bonifacic et al. (1975).

e Zhu (2004), Zhu et al. (2006), Lee and Zhou (1994).

${ }^{\mathrm{f}}$ Zhu (2004), Zhu et al. (2006).

g Zhu (2004), Zhu et al. (2006), Kreidenweis et al. (2003).

${ }^{\mathrm{h}}$ Zhu (2004), Zhu et al. (2006), Hoffman (1986), Kreidenweis et al. (2003).

phases. Section 2 (Methods) describes changes to both the CMAQ gas and cloud chemistry along with other aspects of an updated CCM. Results of CMAQ testing and simulations are reported in Sect. 3 followed by a summary with conclusions.

\section{Methods}

Version 4.6 was the most recent release of CMAQ at the outset of this project. We used the CMAQ4.6 optional configuration that includes an updated version of the carbon bond IV (CBIV) chemical mechanism denoted "CB05" (Yarwood et al., 2005). Because CMAQ is updated every 1-2 years it is impractical to try keeping up to date with the most current version, especially when independent model changes require extensive testing. One consequence of frequent code updates is that a more recent version often contains additional features or improvements that require further changes to ongoing work. CMAQ4.7 includes updates to the gas phase chem- ical mechanism that would have made unnecessary most of the chlorine reaction additions described later in this section.

Another noteworthy caveat about CMAQ4.6 versus CMAQ4.7 involves simulated SOA formation. In our version of CMAQ4.6 (originally introduced into version 4.5.2) SOA formation was updated following the approach of Morris et al. (2006) who introduced aerosol formation from isoprene, formation of sesquiterpenes and aerosol evolution from the polymerization of organic compounds. It is important to note that the SOA treatment in CMAQ4.7 is somewhat different from that in CMAQ4.6 (the newer model tracks SOA formation differently). Regardless, one universal feature of CMAQ that influences its response to emissions changes is its segregation of particle mass into fine and coarse modes. The latter are treated as inert (i.e., soil dust and sea salt) and do not interact with the fine mode. Fine particles in CMAQ do not aggregate into larger particles and cannot react chemically with them. Thus, CMAQ cannot simulate any effect of aerosol mass migrating across size modes. 
Aside from chemistry, the CMAQ configuration applied here followed that used by the VISTAS Regional Planning Organization (see http://vistas-sesarm.org/) as described in Tesche et al. (2008). The VISTAS modeling domain covers all of the continental United States, large portions of Canada, Mexico, and adjacent ocean waters. The CMAQ parent grid over this domain is $4032 \mathrm{~km}$ (west-east) $\times 5328 \mathrm{~km}$ (northsouth) and composed of $36 \times 36 \mathrm{~km}$ grid cells. Meteorological fields used by CMAQ are from simulations of the MM5 meteorological model (Grell et al., 1994). Chemical boundary conditions were derived from a 2002 global simulation using the GEOS-Chem model (Jacob et al., 2005).

\subsection{Gas-phase chemistry modifications}

The modified CB05 mechanism outlined here shares many similarities with, and borrows from, previously published work. Changes were made to the CMAQ4.6 CB05 gas-phase chemical mechanism to include reactive chlorine species, to add reactions for $\mathrm{H}_{2} \mathrm{~S}$ and its derivatives, and to include $S_{\text {org }}$ chemistry. Reactions added to the CB05 mechanism were generally only those for which the products and kinetic rates are known and are sufficiently fast that they will have a significant impact on the evolution of atmospheric sulfur. Consideration was given to include those reactions that, although slow in comparison to competing daytime reactions, would be relatively important at night.

CMAQ4.6 has an option to include a set of gasphase chlorine reactions in $\mathrm{CB} 05$, but it also includes reactions involving hazardous air pollutants (http://www.cmascenter.org/help/model_docs/cmaq/4.6/ HAZARDOUS_AIR_POLLUTANTS.txt). This CB05 enhancement was not used here because it required carrying a number of reactions that are not of interest for simulating natural ozone and aerosols. Instead, a subset of chlorine reactions originally added to the CMAQ4.6 CBIV reaction set (see Table 1, reactions attributable to Tanaka and Allen, 2001) were copied for use in CB05. Also added was Reaction (R1) previously described. These reactions produce radicals $\left(\mathrm{Cl}, \mathrm{ClO}, \mathrm{OH}, \mathrm{HO}_{2}, \mathrm{XO}_{2}\right)$ that react with VOCs, $\mathrm{NO}, \mathrm{H}_{2} \mathrm{~S}$, DMS and their oxidation products. Inorganic sulfur reactions added to CMAQ CB05 (see Table 2) include reactions of $\mathrm{H}_{2} \mathrm{~S}$ with $\mathrm{Cl}, \mathrm{OH}$ and $\mathrm{NO}_{3}$. Likewise, Table 3 lists all the $S_{\text {org }}$ reactions added to the gas-phase mechanism and described previously. The $S_{\text {org }}$ reaction set is similar to that of Yin et al. (1990) and Zaveri (1997) with one major deviation: the $\mathrm{CMAQ}$ version omits the $\mathrm{CH}_{3} \mathrm{SO}_{2}$ and $\mathrm{CH}_{3} \mathrm{SO}_{3}$ species and their reactions. The rationale for this is as follows. The simpler Zaveri mechanism has 11 reactions with $\mathrm{CH}_{3} \mathrm{SO}_{2}$ as a product. In addition, it includes 12 reactions that involve $\mathrm{CH}_{3} \mathrm{SO}_{2}$ or $\mathrm{CH}_{3} \mathrm{SO}_{3}$ as reactants. Thus, 23 reactions are used by Zaveri (1997) to handle these two species. It is not possible to eliminate all these reactions (some are slow enough to neglect), but in all cases reactions forming $\mathrm{CH}_{3} \mathrm{SO}_{2}$ can be replaced by reactions that yield $\mathrm{CH}_{3}+\mathrm{SO}_{2}$ if we assume the thermal decomposition of $\mathrm{CH}_{3} \mathrm{SO}_{2}$ is fast in comparison with $\mathrm{CH}_{3} \mathrm{SO}_{2}$ chemical reactions. The generic SMVGEAR solver implemented in CMAQ was selected to calculate the time evolution of gas mixing ratios. This was necessary because the default optimized solver associated with the CB05 mechanism does not work correctly when changes are made to the reaction set.

\subsection{Heterogeneous chemistry}

Modifying the gas-phase chemistry in CMAQ4.6 is straightforward because the model is designed with a feature that facilitates such changes. However, the model has no such feature regarding its heterogeneous CCM. This required a more extensive reworking of the CCM to accommodate all the necessary changes. Given previous work on heterogeneous chemistry in clouds and the goal of incorporating organic sulfur reactions into CMAQ, we opted to incorporate reactions from the model of Zhu (2004) and Zhu et al. (2006) keeping many features of the old CCM for computational efficiency while adding new features that provide a more realistic approach to cloud chemistry. This is an incremental step in updating a model that is widely used in regulatory settings and, therefore, must maintain some computational shortcuts.

Reactions not included in Zhu's model (i.e., $\mathrm{SO}_{2}$ oxidation by organic peroxides) are retained from the original CMAQ CCM. Table 4 lists the set of all heterogeneous reactions included in the revised CCM. Rate constants are those taken from Zhu (2004) and Zhu et al. (2006) or are currently used in CMAQ. Besides the added reactions involving MHP and PAA, the other differences between the CMAQ revisions and the Zhu's model are in the treatment of the sulfate radical, $\mathrm{Cl}$ and $\mathrm{Cl}^{-}$. Zhu (2004) assumed $[\mathrm{Cl}]_{\mathrm{aq}}=1 \times 10^{-13} \mathrm{M}$, or a factor of 10 less than the value for $\left[\mathrm{SO}_{4}^{-}\right]_{\mathrm{aq}}$. In this work $[\mathrm{Cl}]_{\mathrm{aq}}$ is derived using Henry's Law and the gaseous mixing ratio of ambient $\mathrm{Cl}$. Zhu set $\left[\mathrm{SO}_{4}^{-}\right]_{\mathrm{aq}}=1 \times 10^{-12} \mathrm{M}$, an assumption that served the purposes of his test for the relative importance of various sulfur oxidation reactions. However, using a constant for aqueous $\mathrm{SO}_{4}^{-}$in CMAQ could introduce an artificial source of sulfur into the model. Zhu (2004) includes reactions with $\mathrm{SO}_{4}^{-}$in his study because it was found to be important during his laboratory measurements of DMSO and $\mathrm{CH}_{3} \mathrm{SO}_{2}^{-}$oxidation. He describes three theories of the origin of $\mathrm{SO}_{4}^{-}$in aqueous solution, including (1) a hypothetical reaction chain initiated by $\mathrm{OH}$ reacting with $\mathrm{HSO}_{3}^{-}$that leads to formation of $\mathrm{SO}_{5}^{-}$and eventually $\mathrm{SO}_{4}^{-}$, and (2) $\mathrm{OH}$ reacting with $\mathrm{HSO}_{4}^{-}$. The value $\mathrm{Zhu}$ uses for $\left[\mathrm{SO}_{4}^{-}\right]_{\mathrm{aq}}$ is many orders of magnitude less than the typical concentrations expected for both $\mathrm{HSO}_{3}^{-}$and $\mathrm{HSO}_{4}^{-}$based on reasonable atmospheric concentrations of $\mathrm{SO}_{2}$ and $\mathrm{H}_{2} \mathrm{SO}_{4}$. A working assumption is to link $\left[\mathrm{SO}_{4}^{-}\right]_{\mathrm{aq}}$ to computed levels of $\left[\mathrm{HSO}_{3}^{-}\right]_{\mathrm{aq}}$ and $\left[\mathrm{HSO}_{4}^{-}\right]_{\mathrm{aq}}$ by applying a small proportionality factor to computed ion levels (based on equilibrium 
considerations). This is what is done in the revised CMAQ $\mathrm{CCM}$ in which $\left[\mathrm{SO}_{4}^{-}\right]=\alpha\left\{\left[\mathrm{HSO}_{3}^{-}\right]+\left[\mathrm{HSO}_{4}^{-}\right]\right\}, \alpha \leq 1 \times 10^{-3}$.

Figure 1 illustrates the sensitivity of heterogeneous $\left[\mathrm{SO}_{4}^{2-}\right]_{\mathrm{aq}}$ formation to $\alpha$ and cloud droplet $\mathrm{pH}$ at a temperature of $298 \mathrm{~K}$ and pressure of $1 \mathrm{~atm}$. In this example atmospheric mixing ratios were $\mathrm{SO}_{2}=0.4 \mathrm{ppbV}$, $\mathrm{DMSO}=\mathrm{DMSO} 2=\mathrm{MSIA}=\mathrm{MSA}=0.1 \mathrm{ppbV}$,

$\mathrm{O}_{3}=30 \mathrm{ppbV}, \quad \mathrm{H}_{2} \mathrm{O}_{2}=\mathrm{MHP}=\mathrm{PAA}=0.1 \mathrm{ppbV} \quad$ and $\mathrm{OH}=1 \times 10^{-10} \mathrm{ppbV}$, and cloud liquid water content $\left(W_{\mathrm{c}}\right)$ was $0.5 \mathrm{~g} \mathrm{~m}^{-3}$. When $\mathrm{pH}$ is $\leq 1.5$, steady-state sulfate formation rates from organic and inorganic sulfur oxidation are within a factor of 10 . However, the rates diverge rapidly as $\mathrm{pH}$ increases for all values of $\alpha$ so that at $\mathrm{pH}=7$ sulfate formation from oxidized $S_{\text {org }}$ exceeds that from $\mathrm{SO}_{2}$ by 5 orders of magnitude in the absence of $\left[\mathrm{SO}_{4}^{-}\right]_{\mathrm{aq}}$ and much more when $\left[\mathrm{SO}_{4}^{-}\right]_{\mathrm{aq}}>0$. Note that, in the presence of anthropogenic sources, atmospheric levels of DMS and its oxidation products are much lower than $\mathrm{SO}_{2}$ but this is not necessarily the case in a simulation that examines the chemistry of "natural emissions" only. In addition, droplet $\mathrm{pH}$ is usually $<5.6$ unless there is a major nearby source of alkaline emissions. Thus, for expected droplet acidities, the influence of $\left[\mathrm{SO}_{4}^{-}\right]_{\mathrm{aq}}$ is small when its magnitude compared to $\mathrm{HSO}_{3}^{-}+\mathrm{HSO}_{4}^{-}$is one ppm or less, but its importance grows rapidly with $\mathrm{pH}$ and for $\alpha$ above $1 \times 10^{-6}$. Model sensitivity to $\alpha$ is explored in Sect. 3 .

The dissociation of dissolved acids and bases - plus the presence of soluble salts (ammonium nitrate, sodium and potassium chloride, and magnesium and calcium carbonate) from airborne particles - contribute to an ion balance that determines droplet $\mathrm{pH}$. Ion activity coefficients are computed to calculate the activities of all dissolved ionic species. The total rate of heterogeneous sulfate formation is computed as the sum of the rates of formation from the individual kinetic equations. Rate (transient) equations are integrated for 6or 12-min periods followed by adjustments made to equilibrium concentrations of interstitial gases and aerosol species consumed or produced during the integration. The CMAQ CCM is executed in a quasi steady-state manner with cloud chemistry pausing to allow gas chemistry to proceed before resuming the heterogeneous reactions. This method is used because it is simple to program, has low computational overhead and is easily modified. A disadvantage of this approach is that, by suspending gas-phase chemistry and diffusion during integration of the heterogeneous cloud reactions, it is likely that fast-reacting species will be depleted from the gas phase within the cloud, thereby stopping some heterogeneous reactions (hence, the reason for CMAQ reducing the cloud integration time step from 12 to $6 \mathrm{~min}$ ).

Table 5 lists the gas and aerosol species used to compute droplet acidity for both the CMAQ standard and revised versions of the CCM. The revised CCM adds the effects of MSIA and MSA on droplet acidity. Incorporating the reactions used by Zhu (2004) also requires the addition

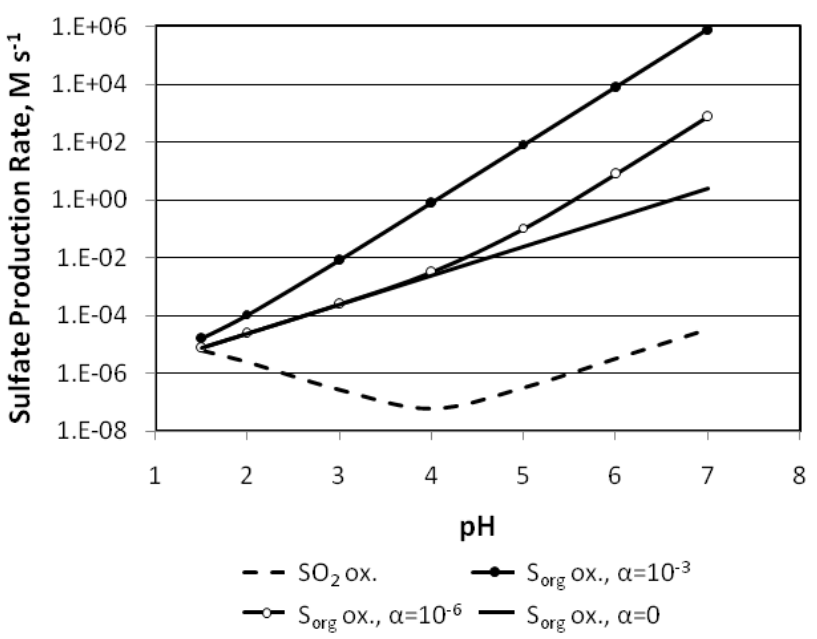

Fig. 1. Comparative steady-state heterogeneous sulfate formation rates in the presence of $\mathrm{SO}_{2}$ and equal parts DMSO and DMSO2 for different levels of $\left[\mathrm{SO}_{4}^{-}\right]_{(\mathrm{aq})}$ as determined from the parameter $\alpha$. Atmospheric conditions are: $298 \mathrm{~K}, 1 \mathrm{~atm}, 0.5 \mu \mathrm{g} \mathrm{m}^{-3}$ cloud liquid water content, $X_{\mathrm{SO}_{2}}=0.4 \mathrm{ppbV}, X_{\mathrm{DMSO}}=0.2 \mathrm{ppbV}$, $X_{\mathrm{DMSO} 2}=0.2 \mathrm{ppbV}, X_{\mathrm{O}_{3}}=30 \mathrm{ppbV}, X_{\mathrm{OH}}=1 \times 10^{-10} \mathrm{ppbV}$, total peroxide $=0.3 \mathrm{ppbV}$.

of $\mathrm{Cl}, \mathrm{Cl}_{2}^{-}, \mathrm{SO}_{4}^{-}$and $\mathrm{OH}$ as reactants in the revised CCM. As shown in the next section, $\mathrm{Cl}$ and $\mathrm{Cl}_{2}^{-}$are in equilibrium with $\mathrm{Cl}^{-}$and this relationship is included in the initial equilibrium calculation. The vapor pressure of $\mathrm{H}_{2} \mathrm{SO}_{4}$ over water is so low that it is assumed to be entirely absorbed by cloud droplets. Initial cloud droplet equilibrium concentrations are computed by calculating the Henry's Law aqueous concentrations of atmospheric gases (adjusting gas phase mixing ratios for highly soluble species), and solving a fourth-order equation in $\left[\mathrm{H}^{+}\right]_{\mathrm{aq}}$. Ion activity coefficients are subsequently calculated and ion aqueous activities are adjusted accordingly.

\subsection{Cloud chemistry mechanism}

The rate at which droplets take up gaseous pollutants can be limited by gaseous diffusion toward the droplets and by the efficiency with which molecules of certain species pass through the gas-droplet interface. These rate-limiting processes are not treated by the default CMAQ CCM and have been added to the revised version. The following treatment is based on Seinfeld and Pandis (1998). Let the activity of water-soluble gas species $i$ at the surface of a cloud droplet be denoted as $C_{\mathrm{s}(i)}$. Diffusion limits both outside and within the droplet and variations in chemical reaction times can result in non-uniform $C_{i}$ throughout the droplet. This characteristic of reactant $C_{i}$ directly affects the temporal evolution of some species and must be treated in the chemical transient equations. The rate of change of the average $C_{i}$ in a droplet of radius $r_{\mathrm{d}}$ is given by 
Table 5. Airborne chemical species ingested by clouds and used to compute droplet acidity.

\begin{tabular}{lcc}
\hline Species & \multicolumn{2}{c}{ CMAQ Cloud Module } \\
\cline { 2 - 3 } & $\begin{array}{c}\text { Original } \\
\text { (version 4.6) }\end{array}$ & Revised \\
\hline $\mathrm{H}_{2} \mathrm{SO}_{4}$ (gas) & $\mathrm{X}$ & $\mathrm{X}$ \\
$\mathrm{SO}_{2}$ (gas) & $\mathrm{X}$ & $\mathrm{X}$ \\
$\mathrm{H}_{2} \mathrm{O}_{2}$ (gas) & $\mathrm{X}$ & $\mathrm{X}$ \\
$\mathrm{CO}_{2}$ (gas) & $\mathrm{X}$ & $\mathrm{X}$ \\
$\mathrm{NH}_{3}$ (gas) & $\mathrm{X}$ & $\mathrm{X}$ \\
$\mathrm{MSIA}$ (gas) & & $\mathrm{X}$ \\
$\mathrm{MSA}$ (gas) & & $\mathrm{X}$ \\
$\mathrm{HCl}$ (gas) & $\mathrm{X}$ & $\mathrm{X}$ \\
$\mathrm{HNO}$ (gas) $_{\mathrm{H}_{2} \mathrm{CO}}$ (gas) & $\mathrm{X}$ & $\mathrm{X}$ \\
$\mathrm{NaCl}$ (aerosol) $_{\mathrm{KCl} \text { (aerosol) }}$ & $\mathrm{X}$ & $\mathrm{X}$ \\
$\mathrm{CaCl}_{2}$ (aerosol) & $\mathrm{X}$ & $\mathrm{X}$ \\
$\mathrm{MgCl}_{2}$ (aerosol) & $\mathrm{X}$ & $\mathrm{X}$ \\
$\mathrm{NH}_{3} \mathrm{NO}_{3}$ (aerosol) & $\mathrm{X}$ & $\mathrm{X}$ \\
\hline
\end{tabular}

$\frac{d C_{i}}{d t}=\frac{x_{\mathrm{mt}}}{R T}\left(p_{i}-\frac{C_{\mathrm{s}(i)}}{\left(H_{\mathrm{A}}\right)_{i}}\right)+X$

where $x_{\mathrm{mt}}$ is the mass transfer coefficient, $R$ is the universal gas constant, $T$ is temperature, $\left(H_{\mathrm{A}}\right)_{i}$ is the Henry's Law constant, $p_{i}$ is the atmospheric partial pressure of the species at a large distance from the droplet, and $X$ is an aqueous chemical reaction term representing any change due to chemical reactivity. To make (1) generic we replace $X$ with $\sum_{k l}\left(Q_{k} P_{k l}\right)-\sum_{j}\left(Q_{i} L_{i j}\right)$ with $P_{k l}$ representing the production rate of species $i$ from a reaction between species $k$ and $l$, and $L_{i j}$ representing the loss rate of species $i$ through its reaction with species $j$. Parameter $Q$ (defined below) is an adjustment factor to account for the non-uniformity of a species activity, $C_{i}$ or $C_{k}$, within the droplet. Note that this assumes co-reactant species $C_{j}$ and $C_{l}$ are uniform within the drop. The transient equation then becomes

$$
\begin{aligned}
& \frac{d C_{i}}{d t}=\frac{x_{\mathrm{mt}}(i)}{R T}\left(p_{i}-\frac{C_{i}}{\left(H_{\mathrm{A}}\right)_{i}}\right)+\sum_{k l}\left(Q_{k} P_{k l}\right) \\
& \quad-\sum_{j}\left(Q_{i} L_{i j}\right)
\end{aligned}
$$

where $x_{\mathrm{mt}}$ is given by

$x_{\mathrm{mt}}(i)=\left[\frac{r_{\mathrm{d}}^{2} R T}{3 \kappa_{\mathrm{g}}}+\frac{r_{\mathrm{d}}\left(2 \pi M_{i} R T\right)^{1 / 2}}{3 a_{i}}\right]^{-1}$

with $\kappa_{\mathrm{g}}$ as the gas diffusivity, $M_{i}$ the molecular weight, and $a_{i}$ the accommodation coefficient. The first product term on the right hand side of (2) represents the diffusion and "sticking" tendency of species $i$ from the air surrounding a droplet (with partial pressure difference $p_{i}-C_{i} / H_{\mathrm{A}}$ ) to the droplet surface. The parameter $a_{i}$ is the ratio of the molecules of species $i$ that adhere to the droplet surface to the total number of molecules that impact the droplet.

In Eq. (2), $Q$ is the ratio of the average droplet activity of the non-uniform species to its activity at the droplet surface. When $Q=1$ the activity (concentration) is uniform. Chemical production and loss terms are derived from the appropriate kinetic rate equations. The backward Euler implicit method is used to solve for $\frac{d C_{i}}{d t}$ :

$C_{i}^{n+1}=C_{i}^{n}+\left(P^{n+1}-C_{i}^{n+1} L^{n+1}\right) \Delta t$

(Seinfeld and Pandis, 1998). Function $Q$ is given by

$Q=3\left(\frac{\operatorname{coth}(q)}{q}-\frac{1}{q^{2}}\right), q=r_{\mathrm{d}}\left(\frac{k C_{\mathrm{U}}}{\kappa_{\mathrm{w}}}\right)^{1 / 2}$

where $k$ is the reaction rate constant, $C_{\mathrm{U}}$ represents the uniform species activity, and $\kappa_{\mathrm{w}}$ is the water diffusivity ( $q$ and $Q$ are dimensionless). In general, $Q<1$ when $k C_{\mathrm{U}}>10^{8} \mathrm{~m}^{-2}$ $\kappa_{\mathrm{w}}$. If $\kappa_{\mathrm{w}}=1 \times 10^{-9} \mathrm{~m}^{2} \mathrm{~s}^{-1}\left(1 \times 10^{-5} \mathrm{~cm}^{2} \mathrm{~s}^{-1}\right)$, then the co-reactant is non-uniform when $k C_{\mathrm{U}}>0.1 \mathrm{~s}^{-1}$. This implies that the non-uniform species is consumed by chemical reaction at a rate $>10 \%$ per second.

Unlike in the default CMAQ CCM, this approach requires that droplet size be defined. Cloud droplets are assumed to be monodisperse (uniform in size) to minimize computer execution time. Measured droplet size distributions described by Byers (1965) for different cloud types - ranging from fog to stratus and convectively-growing cumulus and for $0.02 \mathrm{~g} \mathrm{~m}^{-3}<W_{\mathrm{c}}<0.8 \mathrm{~g} \mathrm{~m}^{-3}$ - were analyzed to estimate their median size characteristics. Median diameters for the analyzed droplet spectra ranged from 5 to $12 \mu \mathrm{m}$. Most values of $W_{\mathrm{c}}$ provided to the CCM are in the range represented by these median diameters, but higher $W_{\mathrm{c}}$ are certainly possible. As used here, when $W_{\mathrm{c}} \leq 1 \mathrm{~g} \mathrm{~m}^{-3}$ the CCM calculated $r_{\mathrm{d}}$ as

$r_{\mathrm{d}}=-3.54 W_{\mathrm{c}}^{2}+7.293 W_{\mathrm{c}}+2.388$

based on the information provided in Byers (1965). For $W_{\mathrm{c}}>1$ radius was set equal to a constant $\left(r_{\mathrm{d}}=6.15 \mu \mathrm{m}\right)$ corresponding to the maximum value derived from this empirical formula. By introducing droplet size the CCM is enabled to accommodate size-specific droplet chemistry in the future.

In another change from the original CMAQ CCM, some chemical species other than sulfate are not assumed to be steady-state. A species is assumed to be steady-state if its droplet concentration is likely to remain nearly constant during the relatively short temporal integration of the transient equations. This is true if a species is not a reactant and is usually a good assumption for reactive species if their concentrations are controlled by a large reservoir in the gas phase (i.e., the species is only partially soluble). For example, $\left[\mathrm{SO}_{2}\right]_{\mathrm{aq}}$, $\left[\mathrm{HSO}_{3}^{-}\right]_{\mathrm{aq}}$ and $\left[\mathrm{SO}_{3}^{2-}\right]_{\mathrm{aq}}$ are dependent on $p_{\mathrm{SO}_{2}}$, the partial pressure of $\mathrm{SO}_{2}$ in air. $\mathrm{SO}_{2}$ is moderately soluble in water 
so that some dissolves into the aqueous phase but a considerable amount remains in the gas phase. In addition, $\left[\mathrm{HSO}_{3}^{-}\right]_{\mathrm{aq}}$ and $\left[\mathrm{SO}_{3}^{2-}\right]_{\mathrm{aq}}$ are partly dependent on $\mathrm{pH}$ which tends to vary little during the period of integration $\left(\left[\mathrm{H}^{+}\right]_{\mathrm{aq}}\right.$ is treated as a steady-state species). Thus, for the short time interval when the transient equations are integrated any $\mathrm{SO}_{2}$ and its derivative ions consumed by chemical reactions are replaced by more $\mathrm{SO}_{2}$ from outside the cloud droplets. This allows the assumption that $\left[\mathrm{SO}_{2}\right]_{\mathrm{aq}},\left[\mathrm{HSO}_{3}^{-}\right]_{\mathrm{aq}}$ and $\left[\mathrm{SO}_{3}^{2-}\right]_{\mathrm{aq}}$ are steadystate.

The steady-state assumption is strengthened by keeping the temporal integration interval short - currently $\leq 4 \mathrm{~min}$ - compared to the much longer temporal integration (6$12 \mathrm{~min}$ ) in the default CCM. Six to twelve minutes is long compared to some of the cloud chemical reaction rates but allowed for more computational efficiency. With faster computer processors it is now feasible to shorten the integration interval. The revised CCM uses a minimum integration step of one minute, the exact interval depending on the consumption rate of certain key species in the reaction set. The maximum interval of four minutes also allows for more frequent updating of gas phase chemistry so that some depleted reactive species in the air are allowed to recover more quickly between cloud chemical integrations than before.

Table 6 lists all the species in the revised CCM, indicates which are treated as steady-state, which are reactive, and which are most likely to have non-uniform droplet concentrations. There are 8 species that are not steady-state and whose temporal changes are represented by transient equations. An analytical solution to this set of equations (see Appendix) is used to calculate changes in transient species.

\subsection{Simulations}

Comparisons between the old and new CCMs, and between different chemical pathways in the new CCM, provide insight into the effects of the new CCM on air quality simulations. Most comparisons described here were done using the natural emissions data set described by Smith and Mueller (2010), i.e., in the absence of anthropogenic emissions. CMAQ behavior in simulating sulfate aerosol was investigated by exercising the model in various chemical configurations to identify its sensitivity to the gas-phase $S_{\text {org }}$ chemistry, cloud $S_{\text {org }}$ chemistry, cloud cover bias, and selected CCM parameters.

A series of CMAQ simulations (Table 8) were made using a variety of model configurations so that a comparison of results from different simulations would provide insight into model behavior. Two simulations were made of the entire year using the fully-modified version of CMAQ4.6. One used the natural-only emissions data set and one used the total (natural plus anthropogenic) emissions data set. In addition, several tests for June 2002 were made to investigate the influence of different gas and cloud chemistry options. June was selected because its intense photochemistry was
Table 6. Species treated in the revised CMAQ cloud module.

\begin{tabular}{|c|c|c|c|c|}
\hline $\begin{array}{l}\text { Index } \\
\text { Number }^{\mathrm{a}}\end{array}$ & Species & $\begin{array}{l}\text { Steady- } \\
\text { state }\end{array}$ & Reactive & $\begin{array}{l}\text { Likely to be } \\
\text { non-uniform }\end{array}$ \\
\hline 1 & $\mathrm{SO}_{2}$ & $X$ & $X$ & \\
\hline 2 & $\mathrm{H}_{2} \mathrm{SO}_{4}$ & $X$ & & \\
\hline 3 & $\mathrm{HSO}_{4}^{-}$ & $X$ & & \\
\hline 4 & $\mathrm{SO}_{4}^{2-}$ & & & \\
\hline 5 & $\mathrm{HSO}_{3}^{-}$ & $X$ & $X$ & \\
\hline 6 & $\mathrm{SO}_{3}^{2-}$ & $X$ & $\mathrm{X}$ & \\
\hline 7 & $\mathrm{H}_{2} \mathrm{O}_{2}$ & & $X$ & $X$ \\
\hline 8 & $\mathrm{HO}_{2}^{-}$ & $\mathrm{b}$ & & \\
\hline 9 & $\mathrm{CO}_{2}$ & $X$ & & \\
\hline 10 & $\mathrm{HCO}_{3}^{-}$ & $X$ & & \\
\hline 11 & $\mathrm{H}^{+}$ & $X$ & & \\
\hline 12 & $\mathrm{CO}_{3}^{2-}$ & $X$ & & \\
\hline 13 & $\mathrm{NH}_{3}$ & $X$ & & \\
\hline 14 & $\mathrm{NH}_{4}^{+}$ & $X$ & & \\
\hline 15 & $\mathrm{OH}^{-}$ & $X$ & & \\
\hline 16 & $\mathrm{CH}_{3} \mathrm{SO}_{2}^{-}$ & & $X$ & \\
\hline 17 & $\mathrm{CH}_{3} \mathrm{SO}_{3}^{-}$ & & $\mathrm{X}$ & \\
\hline 18 & MSIA & & c & \\
\hline 19 & MSA & & $\mathrm{c}$ & \\
\hline 20 & DMS & $X$ & $X$ & $X$ \\
\hline 21 & DMSO & & $X$ & $X$ \\
\hline 22 & DMSO2 & & $X$ & \\
\hline 23 & $\mathrm{SO}_{4}^{-}$ & $X$ & $X$ & \\
\hline 24 & $\mathrm{O}_{3}$ & $X$ & $X$ & \\
\hline 25 & MHP & $\mathrm{X}$ & $X$ & $X$ \\
\hline 26 & PAA & $X$ & $X$ & \\
\hline 27 & $\mathrm{HCl}$ & $X$ & & \\
\hline 28 & $\mathrm{Cl}^{-}$ & $X$ & & \\
\hline 29 & $\mathrm{HNO}_{3}$ & $X$ & & \\
\hline 30 & $\mathrm{NO}_{3}^{-}$ & $X$ & & \\
\hline 31 & $\mathrm{OH}^{3}$ & $X$ & $X$ & \\
\hline 32 & $\mathrm{Cl}$ & $X$ & $X$ & \\
\hline 33 & $\mathrm{Cl}_{2}^{-}$ & $\mathrm{X}$ & $X$ & \\
\hline 34 & $\mathrm{Na}^{+}$ & $X$ & & \\
\hline 35 & $\mathrm{~K}^{+}$ & $X$ & & \\
\hline 36 & $\mathrm{Mg}^{2+}$ & $X$ & & \\
\hline 37 & $\mathrm{Ca}^{2+}$ & $X$ & & \\
\hline
\end{tabular}

a Used as a subscript to identify species in the transient equations.

${ }^{b}$ Although linked to a species that is not steady-state, the activity of this species is only determined for the purpose of computing the initial equilibrium cloud droplet acidity.

$\mathrm{c}$ These species are not themselves reactive but dissociate to ions that are reactive.

expected to strongly differentiate among the different chemistry treatments. June simulations were initiated following a common set of initial conditions derived from a preceding simulation of January-May 2002. The January-May simulation that produced the initial conditions was made using CMAQ4.6 with both revised gas and cloud chemistry options activated. Test results from the first 10 days of June were not analyzed to allow the model to adjust to an abrupt change in internal parameters on 1 June. 
All test simulations were based on natural-only emissions. Test simulation A used the standard (unmodified) version of CMAQ4.6. Test B used the model from test A but with the gas-phase chemical mechanism modified to include the additional reactions described previously. Test $\mathrm{C}$ further modified CMAQ from test B by replacing the standard CCM with the modified version. Test $\mathrm{D}$ used the same version of CMAQ from test $\mathrm{C}$ but blocked cloud droplet uptake of $\mathrm{OH}$, allowing a simulation of the effects of the modified CCM without the additional organic sulfur chemistry. Test $\mathrm{E}$ used the same test C CMAQ code but with artificially enhanced cloud cover over the Pacific Ocean to investigate the influence of clouds on sulfate formation from ocean sulfur emissions. Finally, test $\mathrm{F}$ also used the CMAQ version from test $\mathrm{C}$ but investigated model sensitivity to the sulfate radical proportionality factor $\alpha$ by increasing it from $1 \times 10^{-6}$ to $1 \times 10^{-3}$.

\section{Results}

\subsection{Grid-averaged model time series}

Time series of simulated hourly natural pollutant concentrations for 2002, when averaged over the entire modeling domain, provide insight into the joint behavior of emissions and secondary pollutants. Surface layer mixing ratios of selected gas species and aerosol concentrations were averaged for each hour and then a 24-h smoothing filter applied to suppress diurnal noise. Model output for 29 December 2001 through 10 January 2002 was dropped from the analysis due to chemical spin-up issues. The simulation ended at 00:00 UTC on 1 January 2003 making 31 December incomplete (based on local time). Therefore, all 2002 results are presented for 354 days. Note that all time series plots include "background" contributions from pollutants advected into the domain from the boundaries.

\subsubsection{Photochemical species}

Figure 2 plots grid-averaged surface layer annual time series of ozone, $\mathrm{NO}_{\mathrm{y}}$ (=sum of $\mathrm{NO}, \mathrm{NO}_{2}$ and all other model oxidized nitrogen species) and formaldehyde $\left(\mathrm{CH}_{2} \mathrm{O}\right)$. Both $\mathrm{NO}_{\mathrm{y}}$ and $\mathrm{CH}_{2} \mathrm{O}$ exhibit a clear winter minimum and summer maximum consistent with the expected seasonally-driven photochemical cycle. However, ozone is nearly constant for the first four months, declines slightly May through September, and then levels off for the remainder of the year. Simulations made by removing lightning and wildfire $\mathrm{NO}_{\mathrm{x}}$ emissions revealed that the seasonal patterns of both sources favor higher summer ozone and in no way contribute to the observed ozone pattern (the other source of natural $\mathrm{NO}_{\mathrm{x}}-$ soils - is too small to have a significant effect on the grid average). Thus, the winter/early spring peak in grid-average ozone is imposed on the grid from outside the modeling domain, i.e., from the boundary conditions (BCs).

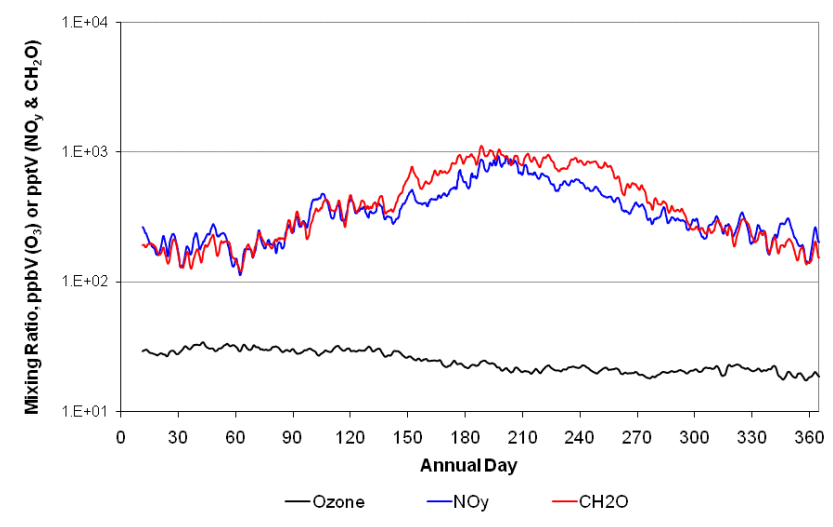

Fig. 2. Grid-averaged time series of three photochemically active species for the natural emissions simulation of 2002. Diurnal noise was removed by applying a $24-\mathrm{h}$ averaging filter.

The global GEOS-Chem model, the source of these BCs, appears to produce a pattern of background ozone that is similar to that produced by Berntsen et al. (1999) except that their modeling also produced a summer minimum in background air arriving in the US from across the Pacific Ocean. They concluded that the higher spring ozone was attributable to Asian emissions having a greater impact at long distances in spring because of enhanced trans-Pacific transport during that time of year. Vingarzan (2004) also found a spring (May) maximum in measured background ozone at "clean" sites in Canada and the US. Finally, Oltmans et al. (2008) analyzed ozone measured at west coast sites usually uninfluenced by air from the mainland, reporting an annual pattern for 2004 that looks a lot like the ozone pattern in Fig. 2 with a MarchMay peak.

Due to the unexpected ozone pattern, the link between GEOS-Chem BCs and ozone within the modeling domain was further investigated by executing CMAQ with all emissions set to zero. This provided details on how ozone responded to pollutants transported across the model boundaries. Ozone throughout the domain is affected by ozone and $\mathrm{NO}_{\mathrm{x}}$ transported across all model boundaries, including the top. At the surface, BC-derived ozone was found to have its highest concentrations across the southwestern US and Mexico in March, with this maximum migrating northward into the central Rocky Mountains in April, and intensifying across these same areas in May. Afterward, BC-derived ozone declines and reaches a near steady-state over the US from August through year's end with ozone simultaneously declining considerably across Canada. This complex behavior is likely controlled by two factors. One is seasonal variations in meteorology, with some of the signal being natural and realistic and some perhaps being artificial (i.e., caused by CMAQ's response to specific meteorological conditions). Some of the spring peak is associated with ozone over higher terrain in the western US, but ozone is also relatively high 
across portions of the east where elevations are low. There is also strong evidence that the amount of pollutants transported into the model domain across the boundaries is higher in winter and spring than in summer and autumn. Blaming all of the imported pollutants on transport from Asia is inaccurate, though. In fact, it appears that in April and May some of the extra ozone, especially across the southern and eastern US, is associated with pollution transported into the southern part of North America from Central America. Enhanced ozone is found along the southern model boundary reaching a peak monthly average of $33 \mathrm{ppb}$ in April. In contrast, ozone over the Pacific Ocean is at a maximum (30 ppb) in January, steadily decreases to a minimum in July (10 ppb) and recovers to values of $15-20 \mathrm{ppb}$ in autumn. One enigma is the disparity in BC-derived ozone for January and December. The December ozone plot was expected to look similar to that for January. However, December BC-derived ozone was much lower, especially over Canada and the US Southwest, suggesting there was something different in the global meteorological patterns for January and December 2002 that significantly affected ozone formation and/or transport into North America.

\subsubsection{Sulfur species}

Time series of modeled sulfur (S) species are illustrated in Fig. 3. Inorganic $\mathrm{S}\left(\mathrm{S}_{\text {inorg }}=\mathrm{SO}_{2}+\mathrm{H}_{2} \mathrm{~S}+\right.$ sulfuric acid $)$ represents the most abundant class of gaseous sulfur compounds. Grid-average values peak above $100 \mathrm{pptV}$ during several periods throughout the year. Grid-average $S_{\text {org }}$ stays below $100 \mathrm{pptV}$, peaking in summer and falling to levels well below those of $S_{\text {inorg }}$ in winter. The $\mathrm{S}$ radicals (labeled "Srad" in Fig. 3) time series is the sum of organic and inorganic gaseous $\mathrm{S}$ intermediate species (e.g., $\mathrm{SH}, \mathrm{HSO}, \mathrm{CH}_{3} \mathrm{~S}$ and $\mathrm{CH}_{3} \mathrm{SCH}_{2}$ ) that are very reactive, have relatively short lifetimes and represent intermediate oxidation steps between DMS and $\mathrm{H}_{2} \mathrm{~S}$ on one hand and MSIA, MSA, $\mathrm{H}_{2} \mathrm{SO}_{4}$ and sulfate on the other. $\mathrm{S}$ radical values peak in summer. The total gaseous S time series ("S-gas") plotted in Fig. 3 indicates that the sum of all natural gaseous species tends to remain fairly constant throughout the year with values in the 100-300 pptV range. Sulfate aerosol concentrations follow the expected seasonal cycle with grid-average values peaking near $0.3 \mu \mathrm{g} \mathrm{m}^{-3}$ in summer.

\subsubsection{Nitrogen species}

Ammonia, $\mathrm{NO}_{\mathrm{z}}\left(=\mathrm{NO}_{\mathrm{y}}-\mathrm{NO}_{\mathrm{x}}\right)$ and ammonium nitrate aerosol time series are plotted in Fig. 4. $\mathrm{NO}_{\mathrm{z}}$, which includes nitric acid, represents the more oxidized of the nitrogen compounds and is a better indicator than $\mathrm{NO}_{\mathrm{x}}$ of precursors to nitrate aerosol formation. All these species follow a seasonal cycle with a grid-averaged summertime maxima. For $\mathrm{NH}_{4} \mathrm{NO}_{3}$ this represents a departure from the expectation that thermodynamics are more favorable for winter formation

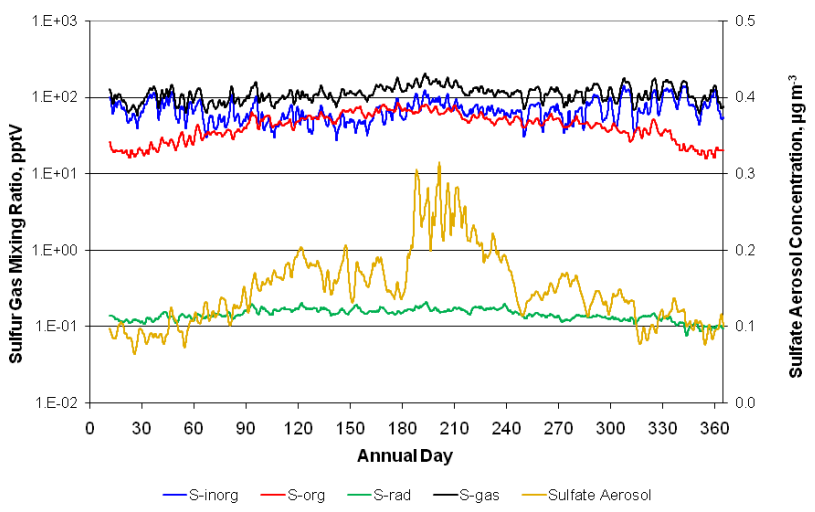

Fig. 3. Grid-averaged time series of various gas and aerosol sulfur species for the natural emissions simulation of 2002. Diurnal noise was removed by applying a 24-h averaging filter.

of the aerosol. In both winter and summer, simulated natural nitrate aerosol concentrations were primarily centered on areas with relatively high ammonia emissions. These areas were over the Pacific and Atlantic Oceans and the Gulf of Mexico, as well as in the vicinity of wildfires in the western US, Florida (winter), and eastern Canada (summer).

\subsubsection{Particles}

Figure 5 illustrates grid-averaged time series for all simulated natural particulate matter: sulfate, nitrate, estimated organic carbon (OC), elemental carbon (EC), fine soil dust, coarse particle mass $\left(\mathrm{PM}_{C}=\right.$ particles in the $2.5-10 \mu \mathrm{m}$ diameter range), fine sea salt and $\mathrm{PM}_{2.5}$ (particles $<2.5 \mu \mathrm{m}$ ). All appeared consistent with expectations based on seasonal emissions behavior and the dependence of atmospheric chemistry on meteorology. Ammonium sulfate/bisulfate, ammonium nitrate, and carbonaceous particles all peak in summer as does total $\mathrm{PM}_{2.5}$ mass. Both fine dust and sea salt are highest in late winter and spring when winds are strongest. Coarse particles follow a similar pattern to that of fine dust.

\subsection{Seasonally-averaged surface concentrations}

Winter and summer grid-average natural ozone mixing ratios and aerosol concentrations are compared in Table 7. The difference between winter and summer "background" ozone is apparent. In the absence of anthropogenic emissions, a westeast ozone gradient is expected in winter due to the transport of anthropogenic emissions from Asia. Sulfate aerosol (including the associated ammonium component) is over a factor of two greater in summer than winter. Organic carbon aerosol mass is more than 6 times greater in summer than winter because of the combined contributions from wildfires and biogenic precursor emissions. Natural coarse particle mass is computed to be less in summer but $\mathrm{PM}_{2.5}$ mass levels 


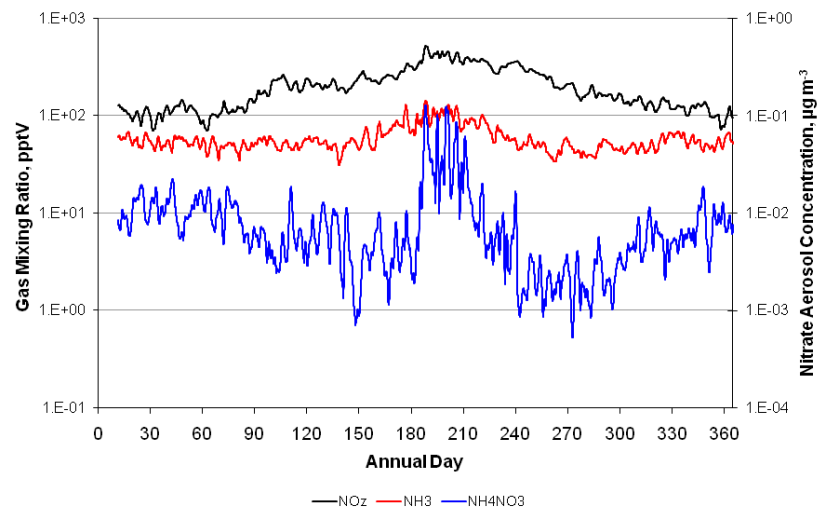

Fig. 4. Grid-averaged time series of $\mathrm{NO}_{z}, \mathrm{NH}_{3}$ and ammonium nitrate aerosol for the natural emissions simulation of 2002. Diurnal noise was removed by applying a 24-h averaging filter.

are much higher. These averages mask a great deal of spatial and temporal variability that is addressed by a future paper.

\subsection{Influences of different gas and cloud chemistry treatments}

Comparisons of test results from 11-30 June are provided in the following sections based on tests A through F.

\subsubsection{Effect of adding reduced sulfur and chlorine gas phase chemistry: tests A and B compared}

Differences between tests A and B reveal the impact of adding reduced sulfur and chlorine gas phase chemical reactions to the standard CB05 mechanism. Changes are quantified as the mean change in variable $x$ relative to reference variable $x_{0}\left[\bar{\Delta}=\left(x-x_{0}\right) / x_{0}\right]$ for the entire period of the test simulations. The pattern in $\mathrm{OH}$ showed little change during the day with more significant changes at night. The resulting average over all June hours (Fig. 6, top) produced decreases over land as large as $60 \%$ and increases over the oceans of up to $60 \%$. Nighttime increases over the water are almost certainly caused by the introduction of DMS and its derivatives. These species react with many other species that also react to remove $\mathrm{OH}$. Thus, $S_{\text {org }}$ compounds act as an additional sink for species that remove $\mathrm{OH}$ thereby slowing the nocturnal depletion and resulting in higher nighttime levels. Widespread inland decreases in $\mathrm{OH}$ are the expected

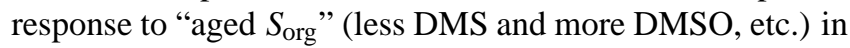
air advected across the continent from the west. Note that the aging of $S_{\text {org }}$ includes formation of $\mathrm{SO}_{2}$.

The only source of secondary sulfate aerosols in standard CMAQ4.6 is $\mathrm{SO}_{2}$ oxidation. The relative change in $\mathrm{SO}_{2}$ due to the change in chemistry treatment is illustrated in Fig. 6 (middle). With meteorology fixed, the $\mathrm{SO}_{2}$ response is determined by $\mathrm{SO}_{2}$ formation from $S_{\text {org }}$ oxidation and to a lesser extent by changes in $\mathrm{OH}$, peroxides, and ozone. Domain-
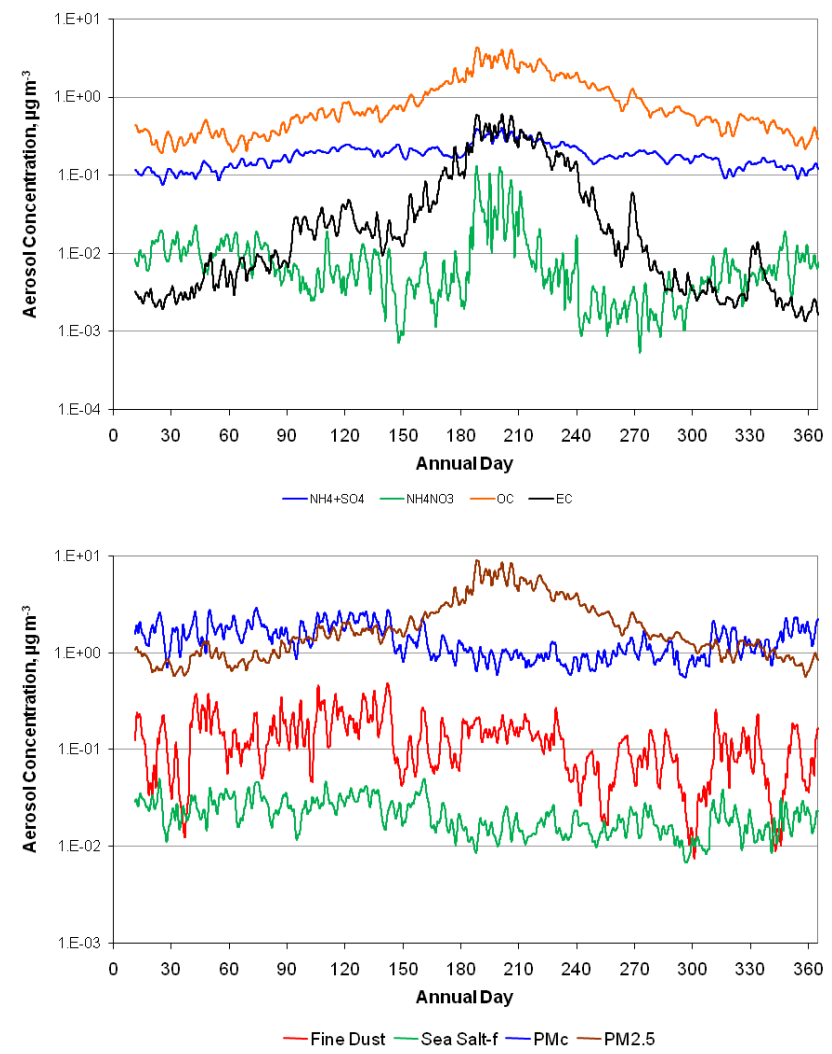

Fig. 5. Grid-averaged time series of simulated particle concentrations for the natural emissions simulation of 2002. Diurnal noise was removed by applying a 24 -h averaging filter.

wide $\mathrm{SO}_{2}$ increases occurred because of the organic sulfur chemistry added to the model. The largest increases - often 3 orders of magnitude and more - occurred over and downwind of grid cells experiencing the highest emission rates of DMS and $\mathrm{H}_{2} \mathrm{~S}$. However, these dramatic increases are due in large part because many of the most affected grid cells have little or no $\mathrm{SO}_{2}$ emissions.

Aerosol sulfate is enhanced everywhere by the chemistry changes (Fig. 6, bottom) but the greatest increases occurred near sources of DMS and $\mathrm{H}_{2} \mathrm{~S}$. Over many cells the increases exceeded a factor of 10 . For ocean cells, sulfate averages increased by nearly $2 \mu \mathrm{g} \mathrm{m}^{-3}$ in some places. Inland sulfate increases averaged $0.1-0.2 \mu \mathrm{g} \mathrm{m}^{-3}$ over south Texas and Florida with smaller increases elsewhere.

\subsubsection{Effect of adding organic sulfur cloud chemistry: tests $B$ and $C$ compared}

Test $\mathrm{C}$ replaced the default CMAQ CCM with one that included $S_{\text {org }}$ reactions. The $\mathrm{OH}$ radical responded with mostly small increases over most of the domain (Fig. 7, top). Overall, changes in $\mathrm{OH}$ were far smaller than those attributable to the change in gas phase chemistry and were generally in response to the consumption of $S_{\text {org }}$ by the heterogeneous 
Table 7. Average simulated winter and summer natural pollutant levels for the modeling domain.

\begin{tabular}{ll}
\hline Test & CMAQ Configuration \& Assumptions ${ }^{\mathrm{a}}$ \\
\hline A & Unmodified CMAQ4.6 using CB05 mechanism \\
B & Test A configuration with CB05 mechanism modified to include DMS and $\mathrm{H}_{2} \mathrm{~S}$ gas phase chemistry \\
C & Test B configuration with standard cloud module replaced by module that includes organic sulfur chemistry \\
D & Test C configuration but with OH cloud uptake blocked \\
E & Test C configuration but with Pacific Ocean clouds enhanced between 250 and $750 \mathrm{~m}^{\mathrm{b}}$ \\
F & Test C configuration with $\alpha=0.001^{\mathrm{c}}$ \\
\hline
\end{tabular}

a All tests were run for the entire month of June.

${ }^{\mathrm{b}}$ All model layers in 250-750 $\mathrm{m}$ range included clouds with minimum cloud water content of $0.5 \mathrm{~g} \mathrm{~m}^{-3}$.

${ }^{\mathrm{c}}$ The proportion, $\alpha$, of $\left[\mathrm{HSO}_{3}^{-}\right]_{\mathrm{aq}}+\left[\mathrm{HSO}_{4}^{-}\right]_{\mathrm{aq}}$ in cloud droplets that is assumed to convert to the sulfate radical, $\mathrm{SO}_{4}^{-}$. All other tests assumed $\alpha=1 \times 10^{-6}$.

Table 8. Average simulated winter and summer natural pollutant levels for the modeling domain.

\begin{tabular}{|c|c|c|}
\hline Pollutant & $\begin{array}{c}\text { Winter } \\
\text { (Dec-Feb) }\end{array}$ & $\begin{array}{c}\text { Summer } \\
\text { (Jun-Aug) }\end{array}$ \\
\hline Ozone (ppbV) & 27.3 & 23.5 \\
\hline Ammonium+sulfate ${ }^{\mathrm{a}}\left(\mu \mathrm{g} \mathrm{m}^{-3}\right)$ & 0.12 & 0.27 \\
\hline Ammonium nitrate ${ }^{\mathrm{a}}\left(\mu \mathrm{g} \mathrm{m}^{-3}\right)$ & 0.01 & 0.02 \\
\hline Organic carbon ${ }^{\mathrm{a}}\left(\mu \mathrm{g} \mathrm{m}^{-3}\right)$ & 0.35 & 2.22 \\
\hline Elemental carbon ${ }^{\mathrm{a}}\left(\mu \mathrm{g} \mathrm{m}^{-3}\right)$ & 0.004 & 0.23 \\
\hline Windblown dust ${ }^{\mathrm{a}}\left(\mu \mathrm{g} \mathrm{m}^{-3}\right)$ & 0.12 & 0.14 \\
\hline Sea salt ${ }^{\mathrm{a}}\left(\mu \mathrm{g} \mathrm{m}^{-3}\right)$ & 0.02 & 0.02 \\
\hline Total $\mathrm{PM}_{2.5}^{\mathrm{b}}\left(\mu \mathrm{g} \mathrm{m}^{-3}\right)$ & 0.91 & 4.66 \\
\hline $\mathrm{PM}_{\mathrm{c}}\left(\mu \mathrm{g} \mathrm{m}^{-3}\right)$ & 1.69 & 1.05 \\
\hline
\end{tabular}

${ }^{\mathrm{a}}$ In the fine particle size fraction (i.e., below $2.5 \mu \mathrm{m}$ ).

$\mathrm{b}$ Assumes organic aerosol mass equal to $1.8^{*} \mathrm{OC}$.

reactions. Changes in $\mathrm{SO}_{2}$ (Fig. 7, middle) were negative over most of the domain. The $\mathrm{SO}_{2}$ response to cloud chemistry changes is caused by moving $S_{\text {org }}$ from the gas phase where it oxidizes to $\mathrm{SO}_{2}$ to the aqueous phase in which $\mathrm{SO}_{2}$ does not form.

Changes in aerosol sulfate in response to cloud chemistry changes (Fig. 7, bottom) occurred primarily where clouds were most prevalent. Significant reductions in sulfate from reduced $\mathrm{SO}_{2}$ gas phase oxidation was offset by enhanced sulfate formation in clouds. Widespread sulfate increases occurred over the Gulf of Mexico, Florida and the western Atlantic east of Florida where diagnostics indicate a persistent cloud cover for the month. Generally, the cloud chemistry changes resulted in higher sulfate across the eastern half of the US. Sulfate increased over the Pacific Ocean off the North American coast by an average of $0.05-0.1 \mu \mathrm{g} \mathrm{m}{ }^{-3}$ due to cloud chemistry but inland cloud effects were much smaller.

\subsubsection{Effect of cloud $\mathrm{OH}$ uptake: tests $\mathrm{D}$ and $\mathrm{B}$ compared}

Test $\mathrm{D}$ was done to determine the relative influence of the $S_{\text {org }}$ versus $\mathrm{SO}_{2}$ cloud chemistry as well as the differences between the old and new $\mathrm{CCM} \mathrm{SO} 2$ chemistry. The former comparison, enabled by not allowing $\mathrm{OH}$ to enter the clouds, was facilitated because aqueous $\mathrm{OH}$ reactions involving $S_{\text {org }}$ are the dominant reactions in the clouds (reactions involving the sulfate radical and chlorine species were of much less significance because of the low value for $\alpha$ - see later comparison of tests $\mathrm{E}$ and F). With both tests $\mathrm{B}$ and $\mathrm{D}$ using the modified gas phase chemical mechanism, their differences illustrate how the original and modified $\mathrm{SO}_{2}$ cloud chemistry differentially influence sulfate formation.

Differences in air concentrations of $\mathrm{SO}_{2}$ and sulfate were generally small across the model domain. This is due in large part to the fact that cloudy cells accounted for only $5 \%$ of all grid cells. However, even in cells that experienced significant cloud cover, $f_{\mathrm{cc}}$, (i.e., $>10 \%$ for a given hour) the differences in hourly averaged $\mathrm{SO}_{2}$ and sulfate were usually small. Surface $\mathrm{SO}_{2}$ mixing ratios beneath cloudy cell columns with $f_{\mathrm{cc}}>0.1$ had a tendency to have somewhat higher values in test $\mathrm{D}$ compared to test $\mathrm{B}$ but the result is misleading. More cells experienced higher $\mathrm{SO}_{2}$ in test $\mathrm{D}$ but the differences were generally $<20 \%$ and were associated with those cells experiencing mixing ratios $<1 \mathrm{ppbV}$. $\mathrm{SO}_{2}$ decreases were larger - some exceeding $75 \%$ - but those tended to occur in the cells with mixing ratios $>1 \mathrm{ppbV}$. The net effect was for higher $\mathrm{SO}_{2}$ in test $\mathrm{D}$ with the domain-averaged value (under clouds) increasing from $0.02 \mathrm{ppbV}$ to $0.23 \mathrm{ppbV}$. Sulfate also responded in test $\mathrm{D}$ with higher values under clouds. The pattern in sulfate differences as seen in Fig. 8 mimicked that in $\mathrm{SO}_{2}$ with small increases occurring in cells with low sulfate and larger decreases occurring in cells with higher sulfate. The net result across the domain was for an increase in sulfate under cloudy conditions from 0.01 to $0.29 \mu \mathrm{g} \mathrm{m}^{-3}$. The effect on all cells was far smaller, however, due to the low level of simulated cloudiness. 

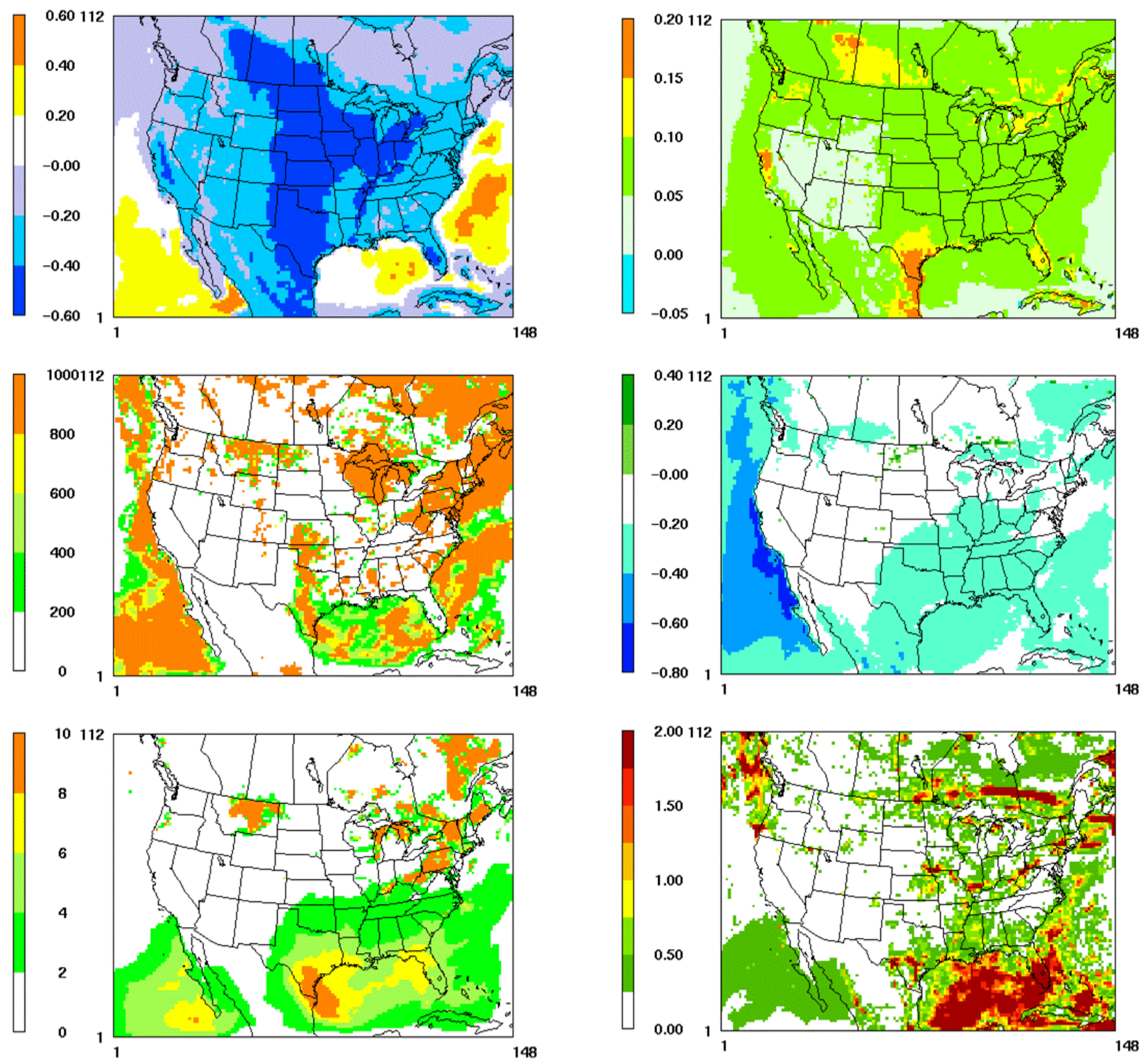

Fig. 6. Mean simulated relative changes, $\bar{\Delta}$, during June in natural levels of airborne pollutants (top: $\mathrm{OH}$; middle: $\mathrm{SO}_{2}$; bottom: aerosol sulfate) due to the introduction of reduced sulfur and chlorine gas chemistry into CMAQ4.6 (i.e., test B changes relative to test A). Model output is for the surface layer.

The different results between tests D and B are associated with differences in the behavior of the original and modified CCMs in their treatment of $\mathrm{SO}_{2}$ chemistry (although some minor differences are caused by the reactions of $S_{\text {org }}$ as previously mentioned). The revised CCM slows down $\mathrm{SO}_{2}$ reactions by putting rate limits on droplet uptake of gaseous reactants and by computing average droplet concentrations (for fast-reacting species like $\mathrm{H}_{2} \mathrm{O}_{2}$ ) that are below the ideal-

Fig. 7. Same as in Fig. 6 except the changes represent the impacts from adding organic sulfur chemistry to the cloud chemistry module (i.e., test $\mathrm{C}$ changes relative to test $\mathrm{B}$ ).

ized concentrations computed in the default CCM. However, the effect of shortening the integration time step for droplet chemistry from 6-12 min down to 1-4 min can have an additional effect of increasing sulfate production under certain conditions (e.g., when reactants would otherwise be depleted for longer time steps) by allowing the gas chemistry to better keep pace with the droplet chemistry. The net effect as illustrated in Fig. 8 appears to be sulfate concentration differences that depend on which CCM feature is more important for a particular situation. Note that comparisons of test results 


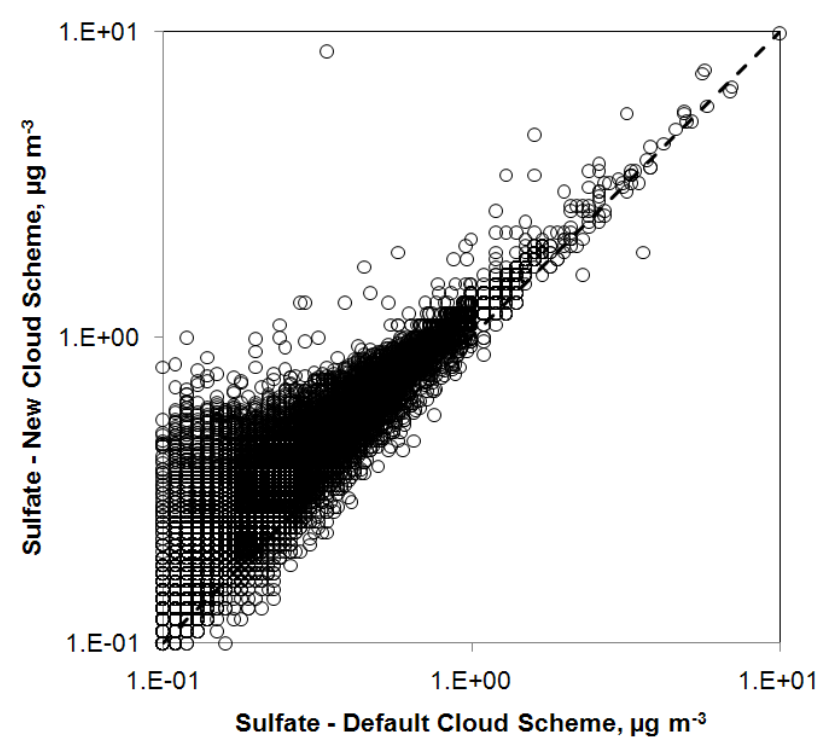

Fig. 8. Comparison of CMAQ hourly sulfate aerosol mass concentrations in the surface layer using the revised (with $S_{\text {org }}$ chemistry turned off) and default (original) cloud chemistry models. The new cloud model produces lower values for some of the higher original cases and higher values for most of the lower original cases. Model differences are a result of differences in the treatment of gaseous reactant uptake by cloud droplets and the timing of cloud and gasphase chemistry.

showed that the changes to $\mathrm{SO}_{2}$ and sulfate concentrations were not caused by differences in calculated wet deposition scavenging.

\subsubsection{Effect of enhancing cloud cover: tests $\mathbf{E}$ and $\mathbf{C}$ compared}

There is evidence that cloud cover is underestimated in CMAQ. This issue has been addressed before (Mueller et al., 2006). For the current modeling, total sky cloud cover was examined using observations from 7 surface stations across the US ${ }^{1}$ and three in the Bahamas ${ }^{2}$. Data were compared with CMAQ output. This allows for a test of how well CMAQ replicates cloud cover by combining cloud output from MM5 with its own sub-grid scale diagnostic cloud module. The comparison suffers from imperfect observations (they are all automated and do not include clouds above $3700 \mathrm{~m}$ ) but is believed to be at least as representative of model performance as would be a comparison based on satellite imagery (the latter suffers from an inability to detect lower clouds beneath elevated cloud cover). CMAQ underestimated cloud cover for 2002 at all 7 US stations, with "clear" $(<1 / 8$ cover) being the predominant condition in the model

\footnotetext{
${ }^{1}$ Los Angeles, Denver, Houston, Atlanta, Tampa, Chicago and Boston.

${ }^{2}$ Freeport, George Town and Nassau.
}

for all but Tampa, Florida. However, for the Bahamian stations the model actually overestimated cloud cover. This appears symptomatic of a CMAQ diagnostic issue over warm waters, including the Gulf of Mexico, where persistent cloud cover was a characteristic problem.

A low cloud cover bias across most of the CMAQ domain suggests that the role of clouds in $S_{\text {org }}$ and $\mathrm{SO}_{2}$ oxidation may be underestimated. This may potentially underestimate natural sulfate aerosol levels. Test E examined the potential impact of this problem on sulfate by simulating enhanced cloud cover over Pacific Ocean grid cells. This was done by inserting clouds into model layers between 250 and $750 \mathrm{~m}$ above sea level when clouds were absent. In addition, minimum cloud liquid water content was arbitrarily set to $0.5 \mathrm{~g} \mathrm{~m}^{-3}$, a value that is roughly half of the highest values used in CMAQ (and output from MM5). This ensured that clouds were able to process air at lower levels moving into the domain from the west throughout the period. Differences between test $\mathrm{E}$ and test $\mathrm{C}$ were used to estimate the upper limit to model sensitivity to clouds. Unlike previous tests, the effect on $\mathrm{OH}$ was fairly small $\left(-0.1 \leq \bar{\Delta}_{\mathrm{OH}} \leq 0.05\right)$ with most changes being negative over the Pacific Ocean.

Responses of $\mathrm{SO}_{2}$ and aerosol sulfate are plotted in Fig. 9. Decreases in $\mathrm{SO}_{2}$ in response to increased cloud cover (Fig. 9, top) occurred over the Pacific Ocean, mostly in the range of -40 to $-80 \%$. Inland over the continent - and downwind from the artificially enhanced cloud cover $-\mathrm{SO}_{2}$ changes were $\pm 20 \%$ and generally decreased as expected from west to east. Sulfate changes (Fig. 9, bottom) were likewise positive over the Pacific Ocean and decreased going eastward. Most ocean grid cells had increases of 20-30\% but some isolated areas experienced increases in excess of $10^{4}$. These latter cells were those that had extremely low sulfate values in the reference simulation and the large relative changes did not indicate a problem with excessively high values. Absolute sulfate changes were no more than $0.15 \mu \mathrm{g} \mathrm{m}^{-3}$ in cells experiencing the highest relative sulfate increases, and the highest simulated concentrations over water were about $2 \mu \mathrm{g} \mathrm{m}^{-3}$. This test demonstrated the impact of persistent cloud cover over the ocean on sulfate formation from DMS.

\subsubsection{Model sensitivity to the aqueous sulfate radical: tests $\mathbf{F}$ and $\mathrm{C}$ compared}

The aqueous sulfate radical, $\mathrm{SO}_{4}^{-}$, is an integral part of the revised CCM as implemented from Zhu (2004). The parameter $\alpha$ used in the revised CMAQ CCM determines the magnitude of $\left[\mathrm{SO}_{4}^{-}\right]_{\mathrm{aq}}$ that reacts with $\mathrm{DMSO}_{\mathrm{aq}}$ and $\mathrm{MSIA}_{\mathrm{aq}}$ (as dissociated to $\left[\mathrm{CH}_{3} \mathrm{SO}_{2}^{-}\right]_{\mathrm{aq}}$ ). Zhu (2004) set $\left[\mathrm{SO}_{4}^{-}\right]_{\mathrm{aq}}=$ $1 \times 10^{-12} \mathrm{M}$. His modeling used an atmospheric $\mathrm{SO}_{2}$ mixing ratio at cloud height of about $6 \mathrm{pptV}$ (CMAQ values for June were $\leq 20 \mathrm{pptV}$ over the Pacific) and he assumed a cloud droplet $\mathrm{pH}$ of 5. Using published Henry's Law and dissociation constants for $\mathrm{SO}_{2}$ yields $\left[\mathrm{HSO}_{3}^{-}\right]_{\mathrm{aq}}=1 \times 10^{-8} \mathrm{M}$ at 

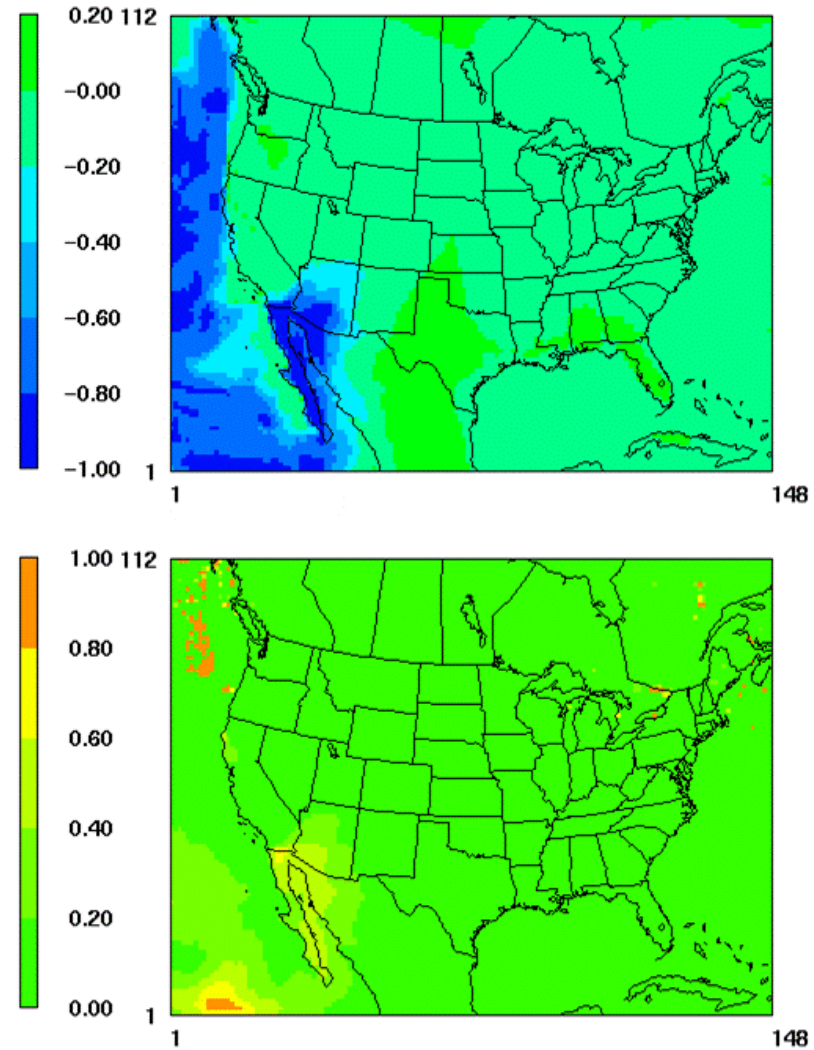

Fig. 9. Average relative changes $(\bar{\Delta})$ for June in surface layer $\mathrm{SO}_{2}$ mixing ratio (top) and sulfate concentration (bottom) incurred by enhancing cloud cover over the Pacific Ocean portion of the modeling domain (i.e., test $\mathrm{E}$ ). The reference case is test $\mathrm{C}$.

$298 \mathrm{~K}$ near sea level. This is equivalent to $\alpha=1 \times 10^{-4}$ in the absence of sulfuric acid. The rate constants for reactions involving the sulfate radical made it the second most important reactant in his model after OH (Zhu, 2004). Based on this, we conservatively assumed $\alpha=1 \times 10^{-6}$ for all but test $\mathrm{F}$ thereby maximizing the contribution from $\mathrm{OH}$ relative to $\mathrm{SO}_{4}^{-}$. However, at a realistic cloud droplet $\mathrm{pH}$ of 4 the value of $\alpha$ would be $1 \times 10^{-3}$ and the sulfate radical would make a much larger contribution to the cloud $S_{\text {org }}$ chemistry, rivaling $\mathrm{OH}$ as the primary reactant oxidizing DMSO. We tested the sensitivity of CMAQ to $\alpha$ by increasing it to $1 \times 10^{-3}$. Thus, test $\mathrm{F}$ results represent an upper limit to the model's sensitivity to sulfate radical in-cloud reactions.

Figure 10 illustrates the relative sensitivity of $\mathrm{SO}_{2}$ and sulfate to $\alpha$. The average change $\bar{\Delta}_{\mathrm{SO}_{2}}$ (Fig. 10, top) produced by increasing $\alpha$ was a net $\mathrm{SO}_{2}$ reduction over the model domain of only $2.4 \%$. However, $\mathrm{SO}_{2}$ reductions averaged $>5 \%$ over the Pacific Ocean where $S_{\text {org }}$ was more prevalent. In Fig. 10 (bottom) $\bar{\Delta}_{\mathrm{SO}_{4}}$ is seen to be positive across the domain $(+5 \%)$ but especially over the Gulf of Mexico and southeastern US $(+26 \%)$. The relative increase in sulfate is larger where sulfate concentrations are originally smaller and
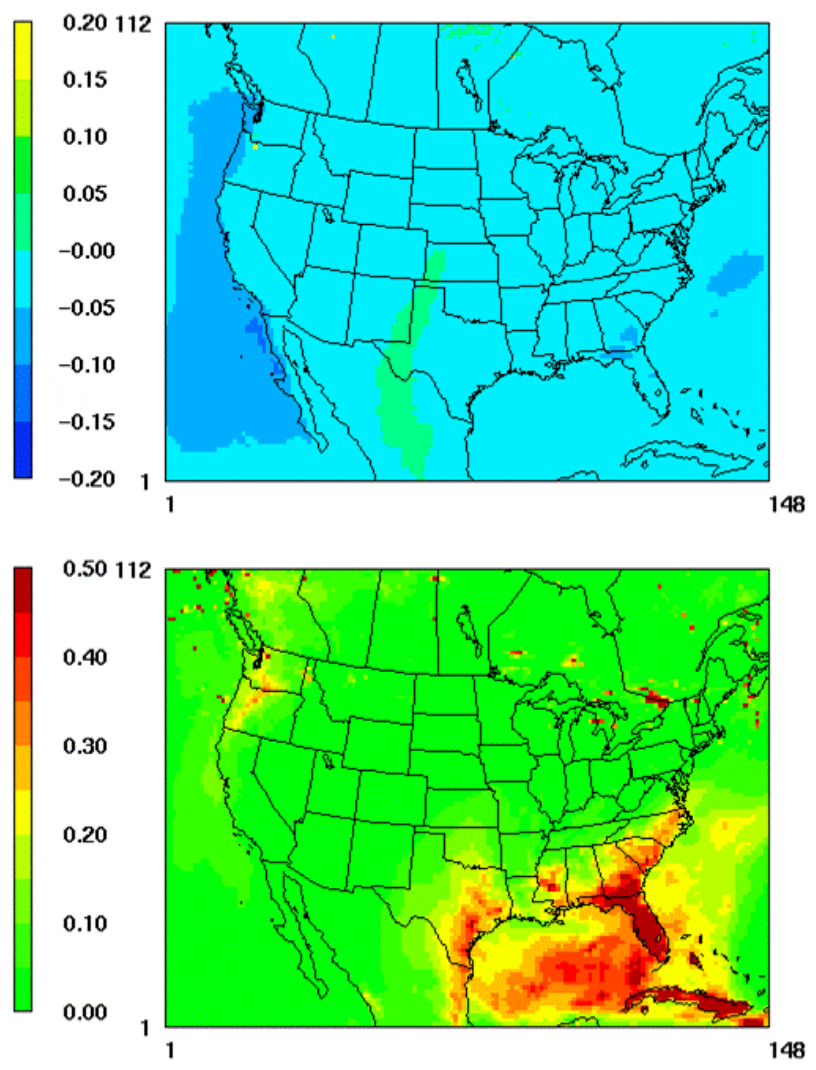

Fig. 10. Average relative changes $(\bar{\Delta})$ for June in surface layer $\mathrm{SO}_{2}$ mixing ratio (top) and sulfate concentration (bottom) incurred by increasing the fraction of sulfate radical formed from aqueous $\mathrm{SO}_{2}$ and $\mathrm{H}_{2} \mathrm{SO}_{4}$ in clouds (i.e., test $\mathrm{F}$ ). The reference case is test $\mathrm{E}$ results.

where more persistent cloud cover has a greater influence on sulfate formation. We conclude that modeled sulfate sensitivity to $\alpha$ is small on average but can be significant in regions with persistent cloud cover. Note that the relatively large change over the southeastern US and adjacent ocean is only about $0.035 \mu \mathrm{g} \mathrm{m}^{-3}$ in absolute terms.

\subsubsection{Ozone and OC sensitivity to different CMAQ chemistry configurations}

The influence of different CMAQ chemistry configurations on ozone was also examined. The case can be made that model $\mathrm{O}_{3}$ results from tests $\mathrm{B}, \mathrm{C}$ and $\mathrm{D}$ were very similar to each other and were significantly different from test $\mathrm{A}$. Test A (original model) produced higher $\mathrm{O}_{3}$ across most of the grid for most hours with a grid-average difference of about $3.5 \mathrm{ppbV}$ compared to test B in which the gas-phase chemistry was modified to include chlorine, $S_{\text {org }}$ and $\mathrm{H}_{2} \mathrm{~S}$ reactions.. This difference is likely due mainly to the extra sink for various radicals included in the gas chemistry for $S_{\text {org }}$ and $\mathrm{H}_{2} \mathrm{~S}$. Test C (implementation of revised cloud model with $S_{\text {org }}$ chemistry) produced on average $1.5 \mathrm{ppbV}$ more $\mathrm{O}_{3}$ than 
test $\mathrm{B}$. Blocking $\mathrm{OH}$ uptake in clouds in test $\mathrm{D}$ resulted in an average reduction in $\mathrm{O}_{3}$ (from test $\mathrm{C}$ ) of only $0.25 \mathrm{ppbV}$.

Differences in $\mathrm{OC}$ between tests $\mathrm{A}$ and $\mathrm{C}$ were also minor. This is primarily because organic aerosol mass is dominated by wildfire emissions that are unaffected by the model chemical schemes. However, SOA is somewhat sensitive to the model chemistry because of the role played by $\mathrm{OH}$ in oxidizing VOCs. Thus, in areas where total organic aerosol mass is primarily composed of SOA mass, the influence of chemical schemes may be important. Average relative differences in SOA (and OC) for tests A and C were nearly nonexistent over the Pacific Ocean but this is not surprising given the nearly total absence of precursor VOC species there. The largest differences occurred over the Gulf of Mexico with decreases averaging about 7\% (Atlantic Ocean decreases were only about 2-3\%). SOA decreases were driven by $\mathrm{OH}$ consumption by $S_{\text {org }}$ both in the gas and aqueous phases. Inland, the largest SOA effects occurred over the Southeast US with SOA decreases averaging nearly 5\%. Across the northern US and Canada SOA increases averaging about 3-4\% were modeled, perhaps due to transport from the south of more unreacted VOCs. Thus, the introduction of $S_{\text {org }}$ chemistry has a small negative impact on SOA - and total OC - mass over the Atlantic Ocean/Gulf of Mexico and adjacent inland areas, and a compensating effect farther north.

In certain grid cells influenced by wildfire emissions, hourly OC differences as large as $\pm 400 \mu \mathrm{g} \mathrm{m}^{-3}$ or more occurred during the 8-30 June test A overlap with test C. Typically, offsetting differences of opposite sign and nearly equal magnitude occurred in adjacent grid cells. The mechanism for this effect is not clear but could be associated with the interaction of $S_{\text {org }}$ with $\mathrm{OH}$. In any event, the net effect when averaged over several hours and across large regions was miniscule.

\subsection{Simulated concentrations in the marine boundary layer}

Table 9 compares average simulated $S_{\text {org }}, \mathrm{SO}_{2}$ and sulfate concentrations in the Pacific Ocean marine boundary layer with average values measured globally by various researchers. The observations represent a variety of measurement techniques, locations and seasons. Reported values were averaged for comparison with the CMAQ June 2002 results from test $\mathrm{C}$ (revised model). Simulated DMS values are consistent with and slightly lower than those reported from field data, the latter usually based on summer season measurement campaigns. Simulated DMSO, MSA and $\mathrm{SO}_{2}$ levels are also lower than the mean observations. This implies that the test $\mathrm{C}$ model configuration may underestimate DMS oxidation rates and, thus, oxidation products. The exception is sulfate with model values being somewhat higher than those measured by several investigators.

A second comparison was made (Table 9) with observations using model results from test $F$ in which DMS oxida- tion and sulfate formation were maximized by increasing the role of the sulfate radical in cloud oxidation of DMSO. As expected, this reduced DMS concentrations about $10 \%$, and decreased DMSO by nearly $50 \%$. It also increased MSA by 50-60\%. However, $S_{\text {org }}$ oxidation product $\mathrm{SO}_{2}$ decreased about $5 \%$ and average sulfate aerosol increased slightly. It is possible that, in test $\mathrm{F}$ over the Pacific Ocean, enhanced cloud oxidation of $S_{\text {org }}$ was mostly offset by lower gas-phase oxidation leading to little net change in $\mathrm{SO}_{2}$ and only a small increase in sulfate.

Another way to examine these data is to normalize DMSO, MSA, $\mathrm{SO}_{2}$ and sulfate by DMS concentrations to determine how closely the relative abundance of simulated DMS oxidation products mimic the observed relative levels thereby providing a better way to evaluate the model's $S_{\text {org }}$ chemistry. Using results from tests $\mathrm{C}$ and $\mathrm{F}, \mathrm{CMAQ}$ values of DMSO/DMS over the Pacific Ocean were 0.005-0.008 compared to an observed ratio of about 0.01 . Likewise, normalized MSA in CMAQ was 0.030-0.067 compared to observe values of $0.067-0.560$, and normalized CMAQ $\mathrm{SO}_{2}$ was $0.076-0.080$ compared with $\sim 0.40$ observed. Finally, normalized sulfate from CMAQ was 0.31-0.46 compared with $0.23-1.60$ observed. The only simulated species whose normalized concentrations were clearly not consistent with observed normalized values was $\mathrm{SO}_{2}$. However, observed maritime $\mathrm{SO}_{2}$ is represented here by data from only one study which may not be representative of the larger population of actual conditions.

These results suggest that the revised CMAQ model chemistry, acting on the new ocean emissions of DMS, does a reasonable job simulating the behavior of organic sulfur. Intermediate products DMSO, MSA and $\mathrm{SO}_{2}$ (and, by implication, DMSO2 and MSIA) tend to fall on the low side of observed values when normalized by DMS. Simulated sulfate levels seem to be relatively unbiased compared to observations made over the oceans.

\subsection{Joint simulation of natural and anthropogenic emissions}

Results from a joint simulation of natural and anthropogenic emissions provide information on the relative contributions of each set of emissions to overall air pollutant levels. Figure 11 compares spatial plots of mean maximum daily 8 -h average $\mathrm{O}_{3}$ mixing ratio and $\mathrm{PM}_{2.5}$ concentration (surface layer) in July as simulated by the revised CMAQ model for the total emissions scenario. Each pollutant plot is accompanied by a plot illustrating the mean July ratio of the anthropogenic to background+natural $(\mathrm{B}+\mathrm{N})$ pollutant contributions. For ozone, $\mathrm{B}+\mathrm{N}$ contributions dominate anthropogenic contributions on over $80 \%$ of the grid. Only near urban areas along the west coast and across the eastern US does the ratio of maximum daily $8-\mathrm{h}$ ozone exceed one and it is rarely $>1.5$. Conversely, this ozone ratio is $<0.5$ across most of the Great Plains, Canada, Mexico and the oceans. 
Table 9. Modified CMAQ4.6 simulated levels of sulfur compounds in the marine boundary layer compared with values from other sources.

\begin{tabular}{|c|c|c|c|c|c|}
\hline \multirow[b]{2}{*}{ Species } & \multirow[b]{2}{*}{ Metric $^{\mathrm{a}}$} & \multicolumn{2}{|c|}{$\mathrm{CMAQ}^{\mathrm{b}}$} & \multirow[b]{2}{*}{ Measured $^{\mathrm{c}}$} & \multirow[b]{2}{*}{ Citation Source } \\
\hline & & Test C & Test F & & \\
\hline \multirow[t]{2}{*}{ DMS } & nanomoles $\mathrm{m}^{-3}$ & 10 & 9 & 5 & Yang et al. (2009) \\
\hline & $\mathrm{pptV}$ & 250 & 225 & 300 & $\begin{array}{l}\text { Yvon and Saltzman (1996), Levasseur et al. (1997), Ayers } \\
\text { and Gillett (2000), Sciare et al. (2001), Jourdain et al. (2003) }\end{array}$ \\
\hline DMSO & $\mathrm{pptV}$ & 2 & 1.1 & 5 & $\begin{array}{l}\text { Sciare et al. (2000), Sciare et al. (2001), } \\
\text { Jourdain et al. (2003) }\end{array}$ \\
\hline \multirow[t]{2}{*}{$\mathrm{MSA}^{\mathrm{d}}$} & nanomoles $\mathrm{m}^{-3}$ & $0.3-0.4$ & $0.5-0.6$ & 2.8 & Watts et al. (1987), Yang et al. (2009) \\
\hline & $\mathrm{pptV}$ & $8-10$ & $13-15$ & 20 & $\begin{array}{l}\text { Ayers and Gillett (2000), Sciare et al. (2001), } \\
\text { Jourdain et al. (2003) }\end{array}$ \\
\hline $\mathrm{SO}_{2}$ & pptV & 19 & 18 & 114 & Sciare et al. (2001) \\
\hline \multirow[t]{2}{*}{ Sulfate } & $\mu \mathrm{g} \mathrm{m}^{-3}$ & 0.3 & 0.4 & 8 & Yang et al. (2009) \\
\hline & $\mathrm{pptV}$ & 90 & 100 & 70 & $\begin{array}{l}\text { Yvon and Saltzman (1996), Sciare et al. (2001), } \\
\text { Jourdain et al. (2003) }\end{array}$ \\
\hline
\end{tabular}

a Maximum mass concentrations and mixing ratios do not usually occur in the same locations or at the same times.

b Average for June 2002 over the Pacific Ocean portion of the modeling domain.

c Averages over multiple samples, locations and seasons.

${ }^{\mathrm{d}}$ It is not clear to what extent MSIA contributes to measured values of MSA given the similarities in the two species and the fact that MSIA can convert to MSA in aqueous solution. Model results presented here include a range of values that reflect this uncertainty and the fact that the model makes a clear distinction between the two $S_{\text {org }}$ components.
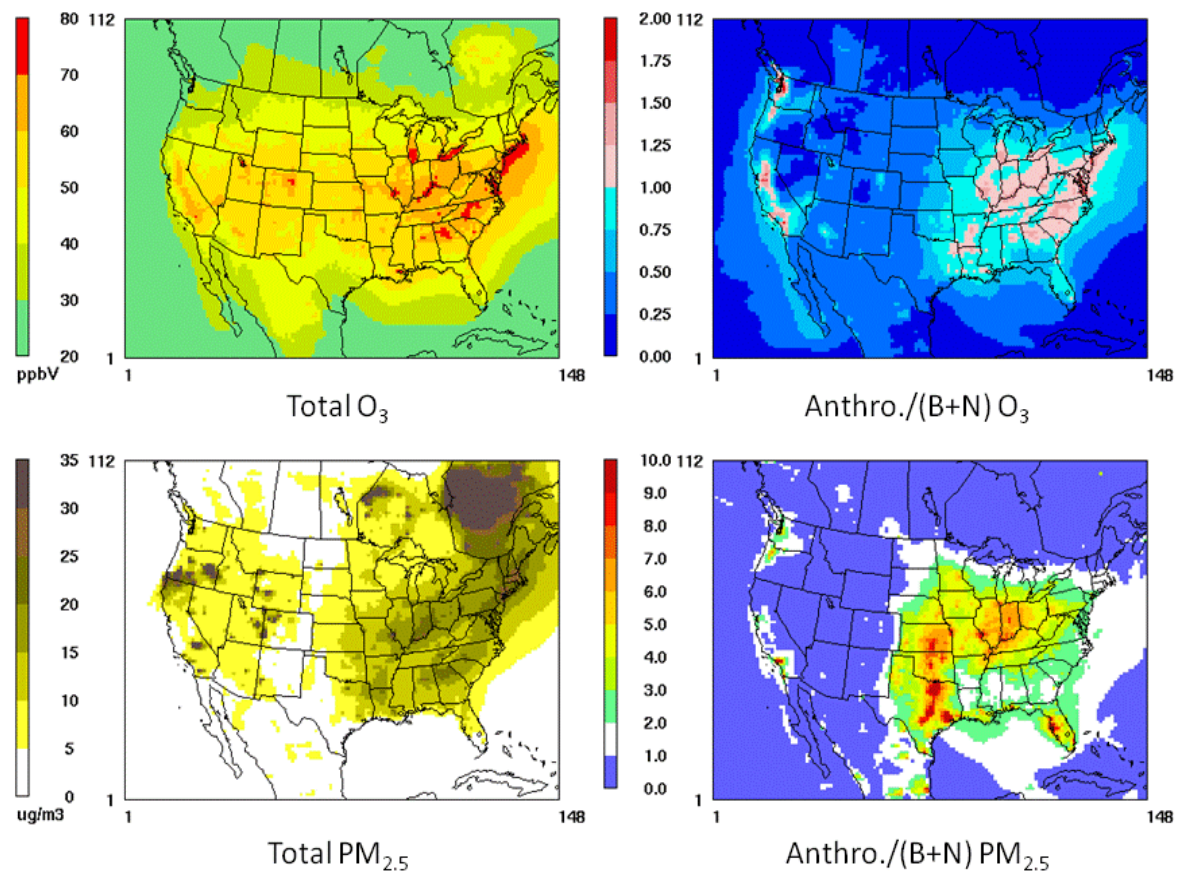

Fig. 11. Mean July 2002 simulated surface values representing total (natural and anthropogenic) maximum daily 8 -h average $\mathrm{O}_{3}$ (upper left), $\mathrm{PM}_{2.5}$ (lower left), and the ratios of anthropogenic to background+natural (B+N) $\mathrm{O}_{3}$ (upper right) and $\mathrm{PM}_{2.5}$ (lower right). 
For $\mathrm{PM}_{2.5}$, a similar story can be told although the area over which the ratio $>1$ covers roughly one third of the domain. In addition, wherever the anthropogenic contribution is high it often exceeds the $\mathrm{B}+\mathrm{N}$ contribution by more than a factor of 5 .

From these results it is apparent that any increase in the ozone productivity of natural pollutants (or decrease in the contribution from anthropogenic pollutants) will only cause more areas to experience $\mathrm{B}+\mathrm{N}$ contributions as the dominant source of ozone. Lightning $\mathrm{NO}_{\mathrm{x}}$ had its greatest impact outside areas experiencing the highest anthropogenic: $\mathrm{B}+\mathrm{N}$ signal. In urban areas saturated with man-made $\mathrm{NO}_{\mathrm{x}}$ emissions the addition of $\mathrm{LNO}_{\mathrm{x}}$ would be mostly inconsequential, or at least would titrate more ozone leading to lower ozone levels. It is on the fringes of urban areas where anthropogenic emissions only occasionally encroach that $\mathrm{LNO}_{\mathrm{x}}$ emissions are likely to be most productive for enhancing ozone.

Adding new sources of natural $\mathrm{PM}_{2.5}$ to the modeling will also increase somewhat the areas experiencing $\mathrm{B}+\mathrm{N}$ contributions as being dominant, but those areas in which anthropogenic effects exceed natural effects are so dominated by man-made emissions that such a change in modeling is unlikely to have much influence on the overall outcome. The greatest increases in sulfate and $\mathrm{PM}_{2.5}$ associated with added model treatments of DMS and $\mathrm{H}_{2} \mathrm{~S}$ occur over oceans adjacent to North America. In many of these areas anthropogenic sources are quite dominant (Fig. 11). Modeled particle sensitivity to $\mathrm{SO}_{2}$ emissions may be decreased somewhat in the presence of DMS and $\mathrm{H}_{2} \mathrm{~S}$ due to competition for available oxidants (especially $\mathrm{OH}$ ).

\section{Summary and conclusions}

A revised CCM and modifications to the CMAQ4.6 CB05 gas-phase chemical mechanism have been tested as a prelude to detailed modeling of natural air pollutant levels. This model, coupled with a natural emissions data base, provides a means of exploring contributions from natural systems/processes to total air quality over the US. Simulated natural + background ozone across the modeling domain has a winter-spring maximum consistent with observations at background sites along the western edge of North America. Various aerosol components have either summer or winterspring maxima depending on their means of formation.

The most notable effects of introducing gas-phase and cloud $S_{\text {org }}$ and gas-phase $\mathrm{H}_{2} \mathrm{~S}$ chemistry changes in CMAQ4.6 are:

- Slight overall decreases in natural ozone - averaging $2 \mathrm{ppbV}$ in summer - and attributable to decreases in $\mathrm{OH}$ and other oxidant radicals.

- Sulfate increases of up to $2 \mu \mathrm{g} \mathrm{m}^{-3}$ on an hourly basis were found over the Pacific Ocean in areas far removed from $\mathrm{SO}_{2}$ sources, and increases of nearly $1 \mu \mathrm{g} \mathrm{m} \mathrm{m}^{-3} \mathrm{oc}-$ curred over the Gulf of Mexico. The largest inland increases occurred over the Southeast US along coastal areas. In the vicinity of high $\mathrm{SO}_{2}$ emissions (e.g., wildfires), the revised chemistry occasionally reduced sulfate levels, sometimes considerably.

- One hour changes in natural organic aerosol mass in response to the added sulfur chemistry were generally moderate except in the vicinity of wildfires where variations of \pm several hundred $\mu \mathrm{g} \mathrm{m}^{-3}$ sometimes occurred during a few hours. However, across the domain, natural organic aerosol mass changes averaged $< \pm 0.1 \mu \mathrm{g} \mathrm{m}^{-3}$ in June.

- In locations over the Pacific Ocean where continuous cloud cover was added to test model sensitivity to cloud presence, modeled sulfate concentrations at the surface increased as much as $0.15 \mu \mathrm{g} \mathrm{m}^{-3}$ and total sulfate concentrations of up to $2 \mu \mathrm{g} \mathrm{m}^{-3}$ occurred. Modeled sulfate sensitivity to the aqueous sulfate radical was smaller, with sulfate increasing by $26 \%$ over the Gulf of Mexico but totaling $<0.04 \mu \mathrm{g} \mathrm{m}^{-3}$ at most.

- Simulated levels of DMS are realistic compared with observations for similar marine environments. Modeled levels of DMS oxidation products (DMSO, MSA and $\mathrm{SO}_{2}$ ) are generally lower, on average, than observations but DMSO and MSA concentrations normalized by DMS are on the lower end of the range in observed normalized values. Sulfate responded positively to increased cloud cover and in-clouds levels of the sulfate radical, and simulated sulfate concentrations over the Pacific Ocean were similar to those reported by field measurements

As for the sulfate radical scaling factor $\alpha$, model results for sulfate do not appear to be very sensitive overall to its magnitude between $1 \times 10^{-6}$ and $1 \times 10^{-3}$ although the model response could be greater when the model is run with a combined natural and anthropogenic emissions data set. The importance of $\alpha$ depends on the presence of substantial cloud cover. A scaling factor toward the upper end of this range, given the tendency for the model to underestimate DMS oxidation products, may produce more realistic effects from the sulfate radical but its importance will depend on the availability of $\mathrm{SO}_{2}$. The effects of the sulfate radical will be most important in coastal areas where substantial levels of $\mathrm{SO}_{2}$ and DMS or more likely to coexist.

One potential consequence of the revised set of chemical reactions, requiring further testing to verify, is the decrease in $\mathrm{SO}_{2} \rightarrow$ sulfate oxidation efficiency in some anthropogenic $\mathrm{SO}_{2}$ plumes when the enhanced natural emissions and "standard" anthropogenic emissions inventories are combined. This effect was seen in natural $\mathrm{SO}_{2}$ plumes from wildfires and is likely associated with the increased competition for 
$\mathrm{OH}$ cited above. Overall, natural and background levels of pollutants together tend to dominate over anthropogenic contributions across large portions of the US. In areas where anthropogenic contributions exceed those from background plus natural sources, human activity can produce $\mathrm{PM}_{2.5}$ levels that are an order of magnitude greater than $\mathrm{B}+\mathrm{N}$ levels. However, the same is not true for ozone for which the highest anthropogenic contributions are typically no more than a factor of two greater than $\mathrm{B}+\mathrm{N}$ levels. The revised model (with implementation of an updated SOA formation scheme) described here represents a new tool for air quality management because it provides a means of evaluating more realistically the influence of natural trace gas emissions on total air pollutant levels.

\section{Appendix A}

\section{Analytical solution to the heterogeneous chemical transient equations}

The equations in this appendix use subscripts to denote the various chemical species. Table A1 is a key that defines the subscript values in terms of the species they represent. The set of heterogeneous chemical transient equations in the modified CMAQ4.6 CCM consists of the following:

Sulfate $: \frac{d C_{4}}{d t}=\frac{1}{\gamma_{2}}$
$\left[\begin{array}{l}\gamma_{1} k_{21,23} Q_{21(23)} \bar{C}_{23} C_{21}+0.7 k_{22,31} \bar{C}_{31} C_{22}+\gamma_{1}^{2} k_{16,23} \bar{C}_{23} C_{16} \\ +\gamma_{1} k_{17,31} \bar{C}_{31} C_{17}+\gamma_{1} k_{5,7} Q_{7(5)} \bar{C}_{5} C_{7}+\left(k_{1,24} \bar{C}_{1} \bar{C}_{24}+\gamma_{1} k_{5,24} \bar{C}_{5} \bar{C}_{24}\right. \\ \left.+\gamma_{2} k_{6,24} \bar{C}_{6} \bar{C}_{24}+\gamma_{1} k_{5,25} Q_{25(5)} \bar{C}_{5} \bar{C}_{25}+\gamma_{1} k_{5,26} \bar{C}_{5} \bar{C}_{26}\right)\end{array}\right]$

$\mathrm{H}_{2} \mathrm{O}_{2}: \frac{d C_{7}}{d t}=g(7, T)\left[p_{7}-\frac{C_{7}}{\left(H_{\mathrm{A}}\right)_{7}}\right]-\gamma_{1} k_{5,7} Q_{7(5)} \overline{C_{5}} C_{7}$ (A2)

$\mathrm{CH}_{3} \mathrm{SO}_{2}^{-}: \frac{d C_{16}}{d t}=\left(k_{21,23} Q_{21(23)} \overline{C_{23}}+k_{21,32} Q_{21(32)} \overline{C_{32}}\right.$

$\left.+k_{21,33} \overline{C_{33}}\right) C_{21}-\left(k_{16,31} \overline{C_{31}}+k_{16,23} \overline{C_{23}}+k_{16,33} \overline{C_{33}}\right) C_{16}$

$\mathrm{CH}_{3} \mathrm{SO}_{3}^{-}: \frac{d C_{17}}{d t}=\left(k_{16,31} \overline{C_{31}}+k_{16,23} \overline{C_{23}}+k_{16,33} \overline{C_{33}}\right) C_{16}$
$-k_{17,31} \overline{C_{31}} C_{17}$

MSIA $: \frac{d C_{18}}{d t}=g(18, T) p_{18}-\frac{g(18, T)}{\left(H_{\mathrm{A}}\right)_{18}} C_{18}$

$+k_{21,31} Q_{21(31)} \bar{C}_{31} C_{21}+\frac{\bar{C}_{11}}{k_{18}} \frac{d C_{16}}{d t}$

MSA $: \frac{d C_{19}}{d t}=g(19, T) p_{19}-\frac{g(19, T)}{\left(H_{\mathrm{A}}\right)_{19}} C_{19}$

$+0.3 k_{22,31} \bar{C}_{31} C_{22}+\frac{\bar{C}_{11}}{k_{19}} \frac{d C_{17}}{d t}$

Atmos. Chem. Phys., 11, 293-320, 2011
Table A1. Index list for aqueous species included in the revised cloud chemistry module ${ }^{\mathrm{a}}$.

\begin{tabular}{lclc}
\hline Species & Index & Species & Index \\
\hline $\mathrm{SO}_{2}$ & 1 & DMS & 20 \\
$\mathrm{H}_{2} \mathrm{SO}_{4}$ & 2 & DMSO & 21 \\
$\mathrm{HSO}_{4}^{-}$ & 3 & DMSO2 & 22 \\
$\mathrm{SO}_{4}^{2-}$ & 4 & $\mathrm{SO}_{4}^{-}$ & 23 \\
$\mathrm{HSO}_{3}^{-}$ & 5 & $\mathrm{O}_{3}$ & 24 \\
$\mathrm{SO}_{3}^{2-}$ & 6 & $\mathrm{MHP}$ & 25 \\
$\mathrm{H}_{2} \mathrm{O}_{2}$ & 7 & $\mathrm{PAA}$ & 26 \\
$\mathrm{HO}_{2}^{-}$ & 8 & $\mathrm{HCl}$ & 27 \\
$\mathrm{CO}_{2}$ & 9 & $\mathrm{Cl}^{-}$ & 28 \\
$\mathrm{HCO}_{3}^{-}$ & 10 & $\mathrm{HNO}_{3}$ & 29 \\
$\mathrm{H}^{+}$ & 11 & $\mathrm{NO}_{3}^{-}$ & 30 \\
$\mathrm{CO}_{3}^{2-}$ & 12 & $\mathrm{OH}^{2-}$ & 31 \\
$\mathrm{NH}_{3}$ & 13 & $\mathrm{Cl}$ & 32 \\
$\mathrm{NH}_{4}^{+}$ & 14 & $\mathrm{Cl}$ & 33 \\
$\mathrm{OH}^{-}$ & 15 & $\mathrm{Na}^{+}$ & 34 \\
$\mathrm{CH}_{3} \mathrm{SO}_{2}^{-}$ & 16 & $\mathrm{~K}^{+}$ & 35 \\
$\mathrm{CH}_{3} \mathrm{SO}_{3}^{-}$ & 17 & $\mathrm{Mg}^{2+}$ & 36 \\
$\mathrm{MSIA}^{-}$ & 18 & $\mathrm{Ca}^{2+}$ & 37 \\
$\mathrm{MSA}^{2+}$ & 19 & & \\
\hline
\end{tabular}

a Abbreviations:

DMS $=$ dimethylsulfide

DMSO $=$ dimethylsulfoxide

DMSO2 $=$ dimethylsulfone

MSIA = methanesulfinic acid

MSA $=$ methanesulfonic acid

MHP = methylhydrogen peroxide

PAA = peroxyacetic acid

$$
\begin{aligned}
& \text { DMSO }: \frac{d C_{21}}{d t}=g(21, T)\left(p_{21}-\frac{C_{21}}{\left(H_{\mathrm{A}}\right)_{21}}\right) \\
& \quad+k_{20,24} Q_{20,24} \overline{C_{20}} \overline{C_{24}}+k_{20,31} Q_{20(31)} \overline{C_{20}} \overline{C_{31}} \\
& \quad-k_{21,24} C_{21} \overline{C_{24}}-k_{21,31} Q_{21(31)} C_{21} \overline{C_{31}} \\
& \quad-k_{21,23} Q_{21(23)} C_{21} \overline{C_{23}}-k_{21,32} Q_{21(32)} C_{21} \overline{C_{32}} \\
& \quad-k_{21,33} C_{21} \overline{C_{33}}
\end{aligned}
$$

$$
\begin{aligned}
& \text { DMSO2: } \frac{d C_{22}}{d t}=g(22, T)\left[p_{22}-\frac{C_{22}}{\left(H_{\mathrm{A}}\right)_{22}}\right] \\
& +k_{21,24} \overline{C_{24}} C_{21}-k_{22,31} \overline{C_{31}} C_{22}
\end{aligned}
$$

where individual variables (activities) are denoted by $C_{j}$ with subscript $j$ indicating the species index number (Table A1). $\gamma_{1}$ and $\gamma_{2}$ are ion activity coefficients. Parameters $k, Q, \bar{C}, g$, $p$, and $H_{\mathrm{A}}$ with subscripts omitted are all known constants at temperature $T$ and are defined as follows: 
$k_{i j}$ : rate constant for reaction between species $i$ and $j$

$Q_{i(j)}$ : concentration adjustment coefficient for non-uniform species $i$ reacting with uniform species $j$

$\bar{C}_{i}$ : activity of steady-state species $i$ (=concentration for non-ionic species)

$g(i, T)$ : mass transfer function for gas species $i$ at temperature $T ;\left[=\frac{x_{m t(i)}}{R T}(\right.$ see paper Eq. 3$\left.)\right]$

$p_{i}$ : gas partial pressure of species $i$

$H_{A(i)}$ : Henry's Law constant for species $i$

Equations (A1-A8) are linear. Their solutions can be obtained by integrating these equations with time. Since the solutions of some equations are dependent on those of others, the procedure for solving Eqs. (A1-A8) is given in this order: $C_{21}, C_{22}, C_{16}, C_{17}, C_{7}, C_{18}, C_{19}$, and $C_{4}$. The initial conditions are $C_{i}(t=0)=B_{i}$, where $i=21,22,16,17,7$, 18,19 , and 4.

Integrating Eq. (A7) with time after proper manipulation and simplification leads to

$C_{21}(t)=\frac{\beta_{21} B_{21}-\alpha_{21}}{\beta_{21}} e^{-\beta_{21} t}+\frac{\alpha_{21}}{\beta_{21}}$,

with coefficients

$$
\begin{aligned}
\alpha_{21} & =g(21, T) p_{21}+k_{20,24} Q_{20,24} \overline{C_{20}} \overline{C_{24}} \\
& +k_{20,31} Q_{20(31)} \overline{C_{20}} \overline{C_{31}},
\end{aligned}
$$

$$
\begin{aligned}
\beta_{21} & =\frac{g(21, T)}{\left(H_{\mathrm{A}}\right)_{21}}+k_{21,24} \overline{C_{24}}+k_{21,31} Q_{21(31)} \overline{C_{31}} \\
& +k_{21,23} Q_{21(23)} \overline{C_{23}}+k_{21,32} Q_{21(32)} \overline{C_{32}}+k_{21,33} \overline{C_{33}}
\end{aligned}
$$

Similarly, the solution for Eq. (A8) after substituting $C_{21}$ with Eq. (A9) is given by

$$
\begin{gathered}
C_{22}(t)=\frac{\eta_{22}}{\beta_{22}-\beta_{21}} e^{-\beta_{21} t}+\left(B_{22}-\frac{\eta_{22}}{\beta_{22}-\beta_{21}}-\frac{\alpha_{22}}{\beta_{22}}\right) e^{-\beta_{22} t} \\
+\frac{\alpha_{22}}{\beta_{22}},
\end{gathered}
$$

where

$$
\left\{\begin{array}{l}
\alpha_{22}=g(22, T) p_{22}+\frac{\alpha_{21}}{\beta_{21}} k_{21,24} \bar{C}_{24}, \\
\beta_{22}=\frac{g(22, T)}{\left(H_{\mathrm{A}}\right)_{22}}+k_{22,31} \overline{C_{31}} \\
\eta_{22}=k_{21,24} \overline{C_{24}} \frac{\beta_{21} B_{21}-\alpha_{21}}{\beta_{21}}
\end{array}\right.
$$

Substituting (A9) into (A3) and integrating with time results in

$$
\begin{gathered}
C_{16}(t)=\frac{\eta_{16}}{\beta_{16}-\beta_{21}} e^{-\beta_{21} t}+\left(B_{16}-\frac{\eta_{16}}{\beta_{16}-\beta_{21}}-\frac{\alpha_{16}}{\beta_{16}}\right) e^{-\beta_{16} t} \\
+\frac{\alpha_{16}}{\beta_{16}}
\end{gathered}
$$

where

$$
\left\{\begin{array}{l}
\alpha_{16}=\frac{\alpha_{21}}{\beta_{21}}\left(k_{21,23} Q_{21(23)} \overline{C_{23}}+k_{21,32} Q_{21(32)} \overline{C_{32}}+k_{21,33} \overline{C_{33}}\right) \\
\beta_{16}=k_{16,31} \overline{C_{31}}+k_{16,23} \overline{C_{23}}+k_{16,33} \overline{C_{33}}, \\
\eta_{16}=\frac{\alpha_{16}}{\alpha_{21}}\left(\beta_{21} B_{21}-\alpha_{21}\right)
\end{array}\right.
$$

Substituting (A14) into (A4) and integrating with time yields

$$
\begin{aligned}
& C_{17}(t)=\frac{\eta_{17}}{\beta_{17}-\beta_{21}} e^{-\beta_{21} t} \\
& +\left(B_{17}-\frac{\eta_{17}}{\beta_{17}-\beta_{21}}-\frac{\delta_{17}}{\beta_{17}-\beta_{16}}-\frac{\alpha_{17}}{\beta_{17}}\right) e^{-\beta_{17} t} \\
& +\frac{\delta_{17}}{\beta_{17}-\beta_{16}} e^{-\beta_{16} t}+\frac{\alpha_{17}}{\beta_{17}}
\end{aligned}
$$

where

$$
\left\{\begin{array}{l}
\alpha_{17}=\frac{\alpha_{16}}{\beta_{16}}\left(k_{16,31} \overline{C_{31}}+k_{16,23} \overline{C_{23}}+k_{16,33} \overline{C_{33}}\right), \\
\beta_{17}=k_{17,31} \overline{C_{31}} \\
\eta_{17}=\frac{\eta_{16}}{\beta_{16}-\beta_{21}}\left(k_{16,31} \overline{C_{31}}+k_{16,23} \overline{C_{23}}+k_{16,33} \overline{C_{33}}\right), \\
\delta_{17}=\left(B_{16}-\frac{\eta_{16}}{\beta_{16}-\beta_{21}}-\frac{\alpha_{16}}{\beta_{16}}\right)\left(k_{16,31} \overline{C_{31}}+k_{16,23} \overline{C_{23}}+k_{16,33} \overline{C_{33}}\right) .
\end{array}\right.
$$

Next, integrating (A2) gives

$C_{7}(t)=\frac{\beta_{7} B_{7}-\alpha_{7}}{\beta_{7}} e^{-\beta_{7} t}+\frac{\alpha_{7}}{\beta_{7}}$

where

$\alpha_{7}=g(7, T) p_{7}$

$\beta_{7}=\frac{g(7, T)}{\left(H_{\mathrm{A}}\right)_{7}}+\gamma_{1} k_{5,7} Q_{7(5)} \overline{C_{5}}$.

Substituting (A9) and (A14) into (A5) and integrating with time leads to

$$
\begin{aligned}
& C_{18}(t)=\frac{\delta_{18}}{\beta_{18}-\beta_{16}} e^{-\beta_{16} t} \\
& +\left(B_{18}-\frac{\eta_{18}}{\beta_{18}-\beta_{21}}-\frac{\delta_{18}}{\beta_{18}-\beta_{16}}-\frac{\alpha_{18}}{\beta_{18}}\right) e^{-\beta_{18} t} \\
& \quad+\frac{\eta_{18}}{\beta_{18}-\beta_{21}} e^{-\beta_{21} t}+\frac{\alpha_{18}}{\beta_{18}},
\end{aligned}
$$

where

$$
\left\{\begin{array}{l}
\alpha_{18}=g(18, T) p_{18}+\frac{\alpha_{21}}{\beta_{21}} k_{21,31} Q_{21(31)} \bar{C}_{31}, \\
\beta_{18}=\frac{g(18, T)}{\left(H_{\mathrm{A}}\right)_{18}}, \\
\eta_{18}=k_{21,31} Q_{21(31)} \bar{C}_{31} \frac{\left(\beta_{21} B_{21}-\alpha_{21}\right)}{\beta_{21}}-\frac{\bar{C}_{11}}{k_{18}} \frac{\beta_{21} \eta_{16}}{\left(\beta_{16}-\beta_{21}\right)}, \\
\delta_{18}=-\frac{\beta_{16} \bar{C}_{11}}{K_{18}}\left(B_{16}-\frac{\eta_{16}}{\beta_{16}-\beta_{21}}-\frac{\alpha_{16}}{\beta_{16}}\right) .
\end{array}\right.
$$

Next, substituting (A12) and (A16) into (A6) and integrating with time results in

$$
\begin{aligned}
& C_{19}(t)=\frac{\theta_{19}}{\beta_{19}-\beta_{16}} e^{-\beta_{16} t}+\frac{\lambda_{19}}{\beta_{19}-\beta_{17}} e^{-\beta_{17} t}+\frac{\delta_{19}}{\beta_{19}-\beta_{21}} e^{-\beta_{21} t} \\
& +\frac{\eta_{19}}{\beta_{19}-\beta_{22}} e^{-\beta_{22} t}+\left(B_{19}-\frac{\eta_{19}}{\beta_{19}-\beta_{22}}-\frac{\delta_{19}}{\beta_{19}-\beta_{21}}\right. \\
& \left.-\frac{\lambda_{19}}{\beta_{19}-\beta_{17}}-\frac{\theta_{19}}{\beta_{19}-\beta_{16}}-\frac{\alpha_{19}}{\beta_{19}}\right) e^{-\beta_{19} t}+\frac{\alpha_{19}}{\beta_{19}},
\end{aligned}
$$


where

$$
\left\{\begin{array}{l}
\alpha_{19}=g(19, T) p_{19}+0.3 k_{22,31} \bar{C}_{31} \frac{\alpha_{22}}{\beta_{22}}, \\
\beta_{19}=\frac{g(19, T)}{\left(H_{\mathrm{A}}\right)_{19}}, \\
\eta_{19}=0.3 k_{22,31} \bar{C}_{31}\left(B_{22}-\frac{\eta_{22}}{\beta_{22}-\beta_{21}}-\frac{\alpha_{22}}{\beta_{22}}\right), \\
\delta_{19}=0.3 k_{22,31} \bar{C}_{31} \cdot \frac{\eta_{22}}{\beta_{22}-\beta_{21}}-\frac{\bar{C}_{11}}{k_{19}} \cdot \frac{\beta_{21} \eta_{17}}{\left(\beta_{17}-\beta_{21}\right)}, \\
\lambda_{19}=-\frac{\beta_{11} \bar{C}_{11}}{k_{19}}\left(B_{17}-\frac{\eta_{17}}{\beta_{17}-\beta_{21}}-\frac{\delta_{17}}{\beta_{17}-\beta_{16}}-\frac{\alpha_{17}}{\beta_{17}}\right), \\
\theta_{19}=-\frac{\bar{C}_{11}}{k_{19}} \cdot \frac{\beta_{16} \delta_{17}}{\left(\beta_{17}-\beta_{16}\right)} .
\end{array}\right.
$$

Finally, integrating Eq. (A1) with time and substituting (A9), (A12), (A14), (A16), and (A18) for $C_{21}, C_{22}, C_{16}, C_{17}$, and $C_{7}$, we obtain

$$
\begin{gathered}
C_{4}(t)=\alpha_{4} t-\frac{\beta_{4}}{\beta_{21}} e^{-\beta_{21} t}-\frac{\eta_{4}}{\beta_{7}} e^{-\beta_{7} t}-\frac{\delta_{4}}{\beta_{22}} e^{-\beta_{22} t}-\frac{\lambda_{4}}{\beta_{16}} e^{-\beta_{16} t} \\
-\frac{\theta_{4}}{\beta_{17}} e^{-\beta_{17} t}+\left(B_{4}+\frac{\beta_{4}}{\beta_{21}}+\frac{\eta_{4}}{\beta_{7}}+\frac{\delta_{4}}{\beta_{22}}+\frac{\lambda_{4}}{\beta_{16}}+\frac{\theta_{4}}{\beta_{17}}\right), \text { (A25) }
\end{gathered}
$$

where

$$
\begin{aligned}
& \alpha_{4}=\frac{\gamma_{1}}{\gamma_{2}} k_{21,23} Q_{21(23)} \bar{C}_{23} \frac{\alpha_{21}}{\beta_{21}}+\frac{0.7}{\gamma_{2}} k_{22,31} \bar{C}_{31} \frac{\alpha_{22}}{\beta_{22}} \\
& +\frac{\gamma_{1}^{2}}{\gamma_{2}} k_{16,23} \bar{C}_{23} \frac{\alpha_{16}}{\beta_{16}}+\frac{\gamma_{1}}{\gamma_{2}} k_{17,31} \bar{C}_{31} \frac{\alpha_{17}}{\beta_{17}} \\
& +\frac{\gamma_{1}}{\gamma_{2}} k_{5,7} Q_{7(5)} \bar{C}_{5} \frac{\alpha_{7}}{\beta_{7}} \\
& +\frac{1}{\gamma_{2}}\left(k_{1,24} \bar{C}_{1} \bar{C}_{24}+\gamma_{1} k_{5,24} \bar{C}_{5} \bar{C}_{24}+\gamma_{2} k_{6,24} \bar{C}_{6} \bar{C}_{24}\right. \\
& \left.+\gamma_{1} k_{5,25} Q_{25(5)} \bar{C}_{5} \bar{C}_{25}+\gamma_{1} k_{5,26} \bar{C}_{5} \bar{C}_{26}\right),
\end{aligned}
$$

$\beta_{4}=\frac{\gamma_{1}}{\gamma_{2}} k_{21,23} Q_{21(23)} \bar{C}_{23} \frac{\beta_{21} B_{21}-\alpha_{21}}{\beta_{21}}$

$+\frac{0.7}{\gamma_{2}} k_{22,31} \bar{C}_{31} \frac{\eta_{22}}{\beta_{22}-\beta_{21}}$

$+\frac{\gamma_{1}^{2}}{\gamma_{2}} k_{16,23} \bar{C}_{23} \frac{\eta_{16}}{\beta_{16}-\beta_{21}}$

$+\frac{\gamma_{1}}{\gamma_{2}} k_{17,31} \bar{C}_{31} \frac{\eta_{17}}{\beta_{17}-\beta_{21}}$,

$\eta_{4}=\frac{\gamma_{1}}{\gamma_{2}} k_{5,7} Q_{7(5)} \bar{C}_{5} \frac{\beta_{7} B_{7}-\alpha_{7}}{\beta_{7}}$,

$$
\delta_{4}=\frac{0.7}{\gamma_{2}} k_{22,31} \bar{C}_{31}\left(B_{22}-\frac{\eta_{22}}{\beta_{22}-\beta_{21}}-\frac{\alpha_{22}}{\beta_{22}}\right),
$$

$$
\begin{aligned}
\lambda_{4}= & \frac{\gamma_{1}^{2}}{\gamma_{2}} k_{16,23} \bar{C}_{23}\left(B_{16}-\frac{\eta_{16}}{\beta_{16}-\beta_{21}}-\frac{\alpha_{16}}{\beta_{16}}\right)+\frac{\gamma_{1}}{\gamma_{2}} k_{17,31} \bar{C}_{31} \\
& \cdot \frac{\delta_{17}}{\beta_{17}-\beta_{16}},
\end{aligned}
$$

$\theta_{4}=\frac{\gamma_{1}}{\gamma_{2}} k_{17,31} \bar{C}_{31}\left(B_{17}-\frac{\eta_{17}}{\beta_{17}-\beta_{21}}-\frac{\delta_{17}}{\beta_{17}-\beta_{16}}-\frac{\alpha_{17}}{\beta_{17}}\right)$.
Acknowledgements. This work was funded by the environmental research program of the Tennessee Valley Authority (TVA) and the Electric Power Research Institute (EPRI). The authors are indebted to the efforts of our colleague, Shandon Smith, who prepared the natural emissions data base used in this project. We are also grateful for the constructive feedback provided by Roger Tanner (TVA) and Eladio Knipping (EPRI) during the course of this work.

Edited by: M. Kanakidou

\section{References}

Atkinson, R., Baulch, D. L., Cox, R. A., Crowley, J. N., Hampson, R. F., Hynes, R. G., Jenkin, M. E., Rossi, M. J., and Troe, J.: Evaluated kinetic and photochemical data for atmospheric chemistry: Volume $\mathrm{I}-$ gas phase reactions of $\mathrm{O}_{\mathrm{x}}, \mathrm{HO}_{\mathrm{x}}, \mathrm{NO}_{\mathrm{x}}$ and $\mathrm{SO}_{\mathrm{x}}$ species, Atmos. Chem. Phys., 4, 1461-1738, doi:10.5194/acp-41461-2004, 2004.

Atkinson, R., Baulch, D. L., Cox, R. A., Crowley, J. N., Hampson, R. F., Hynes, R. G., Jenkin, M. E., Rossi, M. J., Troe, J., and IUPAC Subcommittee: Evaluated kinetic and photochemical data for atmospheric chemistry: Volume II - gas phase reactions of organic species, Atmos. Chem. Phys., 6, 3625-4055, doi:10.5194/acp-6-3625-2006, 2006.

Atkinson, R., Baulch, D. L., Cox, R. A., Crowley, J. N., Hampson, R. F., Hynes, R. G., Jenkin, M. E., Rossi, M. J., and Troe, J.: Evaluated kinetic and photochemical data for atmospheric chemistry: Volume III - gas phase reactions of inorganic halogens, Atmos. Chem. Phys., 7, 981-1191, doi:10.5194/acp-7-981-2007, 2007.

Ayers, G. P. and Gillett, R. W.: DMS and its oxidation products in the remote marine atmosphere: implications for climate and atmospheric chemistry, J. Sea Res., 43, 275-286, 2000.

Behnke, W., George, C., Scheer, V., and Zetzsch, C.: Production and decay of $\mathrm{ClNO}_{2}$ from the reaction of gaseous $\mathrm{N}_{2} \mathrm{O}_{5}$ with $\mathrm{NaCl}$ solution: bulk and aerosol experiments, J. Geophys. Res., 102, 3795-3804, 1997.

Berntsen, T. K. and Isaksen, I. S. A.: A global 3D chemical transport model for the troposphere: model description and $\mathrm{CO}$ and $\mathrm{O}_{3}$ results, J. Geophys. Res, 102, 21239-21280, 1997.

Berntsen, T. K., Karlsdóttir, S., and Jaffe, D. A.: Influence of Asian emissions on the composition of air reaching the north western United States, Geophys. Res. Let., 26, 2171-2174, 1999.

Bonifacic, M., Mockel, H., Bahnemann, D., and Asmus, K. D.: Formation of positive-ions and other primary species in oxidation of sulfides by hydroxyl radicals, Journal of the Chemical SocietyPerkin Transactions 2(7), 675-685, 1975.

Byers, H. R.: Elements of Cloud Physics, The University of Chicago Press, Chicago, 142-146, 1965.

Chameides, W., Lindsay, R., Richardson, J., and Kiang, C.: The role of biogenic hydrocarbons in urban photochemical smog: Atlanta as a case study, Science, 241, 1473-1475, 1988.

Chawla, O. P. and Fessenden, R. W.: Electron-spin resonance and pulse-radiolysis studies of some reactions of $\mathrm{SO}_{4}^{-}$, J. Phys. Chem., 79, 2693-2700, 1975.

De Valk, J. P. J. M. M. and van der Hage, J. C. H.: A model for cloud chemistry processes suitable for use in long range transport models: a sensitivity study, Atmos. Environ., 28, 1653-1663, 1994. 
EPA: Guidance for Tracking Progress under the Regional Haze Rule, Office of Air Quality Planning and Standards, Research Triangle Park, NC, EPA-454/B-03-004, 2003.

EPA: Review of the National Ambient Air Quality Standards for Particulate Matter: Policy Assessment of Scientific and Technical Information, Office of Air Quality Planning and Standards, Research Triangle Park, NC, EPA-452/R-05-005, 2005.

Erickson III, D. J., Seuzaret, C., Keene, W. C., and Gong, S. L.: A general circulation model based calculation of $\mathrm{HCl}$ and $\mathrm{ClNO}_{2}$ production from sea salt dechlorination: reactive chlorine emissions inventory, J. Geophys. Res, 104, 8347-8372, 1999.

Ervens, B., Carlton, A. G., Turpin, B. J., Altieri, K. E., Kreidenweis, S. M., and Feingold, G.: Secondary organic aerosol yields from cloud-processing of isoprene oxidation products, Geophys. Res. Lett., 35, L02816, doi:10.1029/2007GL031828, 2008.

Finlayson-Pitts, B. J. and Pitts Jr., J. N.: Chemistry of the Upper and Lower Atmosphere, Academic Press, San Diego, CA, 2000.

Friedl, R. R., Brune, W. H., and Anderson, J. G.: Kinetics of SH with $\mathrm{NO}_{2}, \mathrm{O}_{3}, \mathrm{O}_{2}$, and $\mathrm{H}_{2} \mathrm{O}_{2}$, J. Phys. Chem., 89, 5505-5510, 1985.

Gershenzon, M., Davidovits, P., Jayne, J. T., Kolb, C. E., and Worsnop, D. R.: Simultaneous uptake of DMS and ozone on water, J. Phys. Chem. A, 105, 7031-7036, 2001.

Graedel, T. E., Bates, T. S., Bouwman, A. F., Cunnold, D., Dignon, J., Fung, I., Jacob, D. J., Lamb, B. K., Logan, J. A., Marland, G., Middleton, P., Pacyna, J. M., Placet, M., and Veldt, C.: A compilation of inventories of emissions to the atmosphere, Global Biogeochem. Cy., 7, 1-26, 1993.

Grell, G. A., Dudhia, J., and Stauffer, D. R.: A description of the fifth-generation Penn State/NCAR Mesoscale Model (MM5), NCAR Tech. Note, NCAR/TN-398+STR, 122 pp., 1994.

Henze, D. K. and Seinfeld, J. H.: Global secondary organic aerosol from isoprene oxidation, Geophys. Res. Lett., 33, L09812, doi:10.1029/2006GL025976, 2006.

Herrmann, H., Ervens, B., Jacobi, H.-W., Wolke, R., Nowacki, P., and Zellner, R.: CAPRAM 2.3: a chemical aqueous phase radical mechanism for tropospheric chemistry, J. Atmos. Chem., 36, 231-284, 2000.

Hoffman, M. R.: On the kinetics and mechanism of oxidation of aquated sulfur-dioxide by ozone, Atmos. Environ., 20, 11451154, 1986.

Huie, R. E. and Clifton, C. L.: Temperature-dependence of the rate constants for reactions of the sulfate radical, $\mathrm{SO}_{4}^{-}$, with anions, J. Phys. Chem, 94, 8561-8567, 1990.

Jacob, D. J., Park, R., and Logan, J. A.: Documentation and Evaluation of the GEOS-Chem Simulation for 2002 Provided to the VISTAS Group, Harvard University, available at: http://vistassesarm.org/documents/Harvard_GEOS-CHEM_ FinalReport_20050624.doc, 2005.

Jourdain, B., Legrand, M., and Preunkert, S.: Multiple year-round atmospheric records of DMS, DMSO, sea-salt and sulfur (MSA and non-sea-salt sulfate) aerosols at Dumont D'Urville (Antarctica) (December 1998-August 2002), EGS-AGU-EUG Joint Assembly, Nice, France, 6-11 April, 2003.

Kaminski, J. W., Neary, L., Struzewska, J., McConnell, J. C., Lupu, A., Jarosz, J., Toyota, K., Gong, S. L., Côté, J., Liu, X., Chance, K., and Richter, A.: GEM-AQ, an on-line global multiscale chemical weather modelling system: model description and evaluation of gas phase chemistry processes, Atmos. Chem. Phys., 8,
3255-3281, doi:10.5194/acp-8-3255-2008, 2008.

Karamchandani, P. and Venkatram, A.: The role of nonprecipitating clouds in producing ambient sulfate during summer: results from simulations with the Acid Deposition and Oxidant Model (ADOM), Atmos. Environ., 26A, 1041-1052, 1992.

Kaynak, B., Hu, Y., Martin, R. V., Russell, A. G., Choi, Y., and Wang, Y.: The effect of lightning $\mathrm{NO}_{\mathrm{x}}$ production on surface ozone in the continental United States, Atmos. Chem. Phys., 8, 5151-5159, doi:10.5194/acp-8-5151-2008, 2008.

Knipping, E. M. and Dabdub, D.: Impact of chlorine emissions from sea-salt aerosol on coastal urban ozone, Environ. Sci. Technol., 37, 275-284, 2003.

Koo, B., Chien, C.-J., Tonnesen, G., Morris, R., Johnson, J., Sakulyanontvittaya, T., Piyachaturawat, P., and Yarwood, G.: Natural emissions for regional modeling of background ozone and particulate matter and impacts on emissions control strategies, Atmos. Environ., 44, 2372-2382, doi:10.1016/j.atmosenv.2010.02.041, 2010.

Kreidenweis, S. M., Penner, J. E., Yin, F., and Seinfeld, J. H.: The effects of dimethylsulfide upon marine aerosol concentrations, Atmos. Environ., 25A, 2501-2511, 1991.

Kreidenweis, S. M., Walcek, C. J., Feingold, G., Gong, W. M., Jacobson, M. Z., Kim, C. H., Liu, X. H., Penner, J. E., Nenes, A., and Seinfeld, J. H.: Modification of aerosol mass and size distribution due to aqueous-phase $\mathrm{SO}_{2}$ oxidation in clouds: comparisons of several models, J. Geophys. Res.-Atmos., 108, 4213, doi:10.1029/2002JD002697, 2003.

Kukui, A., Bossoutrot, V., Laverdet, G., and Le Bras, G.: Mechanism of the reaction of $\mathrm{CH}_{3} \mathrm{SO}$ with $\mathrm{NO}_{2}$ in relation to atmospheric oxidation of dimethyl sulfide: experimental and theoretical study, J. Phys. Chem., 104, 935-946, 2000.

Kukui, A., Borissenko, D., Laverdet, G., and Le Bras, G.: Gas phase reactions of $\mathrm{OH}$ radicals with dimethyl sulfoxide and methane sulfinic acid using turbulent flow reactor and chemical ionization mass spectrometry, J. Phys. Chem. A, 107, 5732-5742, 2003.

Lee, Y. N. and Zhou, X. L.: Aqueous reaction-kinetics of ozone and dimethylsulfide and its atmospheric implications, J. Geophys. Res.-Atmos. 99, 3597-3605, 1994.

Levasseur, M., Sharma, S., Cantin, G., Michaud, S., Gosselin, M., and Barrie, L.: Biogenic sulfur emissions from the Gulf of Saint Lawrence and assessment of its impact on the Canadian east coast, J. Geophys. Res, 102(D23), 28025-28039, 1997.

Lin, C.-Y. C., Jacob, D. J., Munger, J. W., and Fiore, A. M.: Increasing background ozone in surface air over the United States, Geophys. Res. Lett., 27, 3465-3468, 2000.

Lucas, D. D. and Prinn, R. G.: Sensitivities of gas-phase dimethylsulfide oxidation products to the assumed mechanisms in a chemical transport model, J. Geophys. Res, 110, D21312, doi:10.1029/2004JD005386, 2005.

Mansell, G. E., Lau, S., Russell, J., and Omary, M.: Final Report: Fugitive Wind Blown Dust Emissions and Model Performance Evaluation, Phase II. Prepared for the Western Governors Association by ENVIRON International Corporation, Novato, CA and the University of California at Riverside Center for Environmental Research and Technology, Riverside, CA, 2006.

Möller, D. and Mauersberger, G.: Cloud chemistry effects on tropospheric photooxidants in polluted atmosphere - model results, J. Atmos. Chem., 14, 153-165, 1992.

Morris, R. E., Koo, B., Guenther, A., Yarwood, G., McNally, 
D., Tesche, T. W., Tonnesen, G., Boylan, J., and Brewer, P.: Model sensitivity evaluation for organic carbon using two multipollutant air quality models that simulate regional haze in the southeastern United States, Atmos. Environ., 40, 4960-4972, 2006.

Mueller, S. F., Bailey, E. M., Cook, T. M., and Mao, Q.: Treatment of clouds and the associated response of atmospheric sulfur in the Community Multiscale Air Quality (CMAQ) modeling system, Atmos. Environ., 40, 6804-6820, 2006.

National Aeronautics and Space Administration: Chemical Kinetics and Photochemical Data for Use in Stratospheric Modeling - Evaluation Number 12, Jet Propulsion Laboratory, Publication 97-4, 266 pp., available at: http://ntrs.nasa.gov/archive/nasa/casi. ntrs.nasa.gov/19970037557_1997085720.pdf, 1997.

National Acid Precipitation Assessment Program: The Regional Acidic Deposition Model and Engineering Model, Report 4, in: Acid Deposition: State of Science and Technology, edited by: Irving P. M., Vol. 1, Emissions, Atmospheric Processes, and Deposition, Office of the Director, Washington, DC, 67-69, 1991.

Oltmans, S. J., Lefohn, A. S., Harris, J. M., and Shadwick, D. S.: Background ozone levels of air entering the west coast of the US and assessment of longer-term changes, Atmos. Environ., 42, 6020-6038, 2008.

Park, R. J., Jacob, D. J., Field, B. D., and Yantosca, R. M.: Natural and transboundary pollution influences on sulfate-nitrateammonium aerosols in the United States: implications for policy, J. Geophys. Res, 109, D15205, doi:10.1029/2003JD004473, 2004.

Pickering, K. E., Wang, Y., Tao, W.-K., Price, C., and Müller, J.F.: Vertical distributions of lightning $\mathrm{NO}_{\mathrm{x}}$ for use in regional and global chemical transport models, J. Geophys. Res, 103, 3120331216, 1993.

Sciare, J., Kanakidou, M., and Mihalopoulos, N.: Diurnal and seasonal variation of atmospheric dimethylsulfoxide at Amsterdam Island in the southern Indian Ocean, J. Geophys. Res, 105(D13), 17257-17265, 2000.

Sciare, J., Baboukas, E., and Mihalopoulos, N.: Short-term variability of atmospheric DMS and its oxidation products at Amsterdam Island during summer time, J. Atmos. Chem., 39, 281-302, doi:10.1023/A:1010631305307, 2001.

Seinfeld, J. H. and Pandis, S. N.: Atmospheric Chemistry and Physics, John Wiley \& Sons, New York, 627-634, 1998.

Smith, S. N. and Mueller, S. F.: Modeling natural emissions in the Community Multiscale Air Quality (CMAQ) ModelI: building an emissions data base, Atmos. Chem. Phys., 10, 4931-4952, doi:10.5194/acp-10-4931-2010, 2010.

Tanaka, P. L. and Allen, D. T.: Incorporation of chlorine reactions into the carbon bond-IV mechanism: mechanism updates and preliminary performance evaluation, report on contract no. $9880077600-18$ between the University of Texas and the Texas Natural Resource Conservation Commission, Center for Energy and Environmental Resources, University of Texas, Austin, TX, 2001.
Tesche, T. W., Morris, R., Tonnesen, G., McNally, D., Boylan, J., and Brewer, P.: CMAQ/CAMx annual 2002 performance evaluation over the eastern US, Atmos. Environ., 40, 4906-4919, 2008.

Van den Berg, A. R., Dentener, F. J., and Lelieveld, J.: Modelling the chemistry of the marine boundary layer; sulphate formation and the role of sea salt aerosol particles, J. Geophys. Res, 105, 11671-11698, 2000.

Vingarzan, R.: A review of surface ozone background levels and trends, Atmos. Environ., 38, 3431-3442, 2004.

Watts, S. F., Watson, A., and Brimblecombe, P.: Measurements of the aerosol concentrations of methanesulphonic acid, dimethyl sulphoxide and dimethyl sulphone in the marine atmosphere of the British Isles, Atmos. Environ., 21, 2667-2672, 1987.

Williams, J. E., Dentener, F. J., and van den Berg, A. R.: The influence of cloud chemistry on $\mathrm{HO}_{\mathrm{x}}$ and $\mathrm{NO}_{\mathrm{x}}$ in the moderately polluted marine boundary layer: a 1-D modelling study, Atmos. Chem. Phys., 2, 39-54, doi:10.5194/acp-2-39-2002, 2002.

Yang, G.-P., Zhang, H.-H., Su, L.-P., and Zhou, L.-M.: Biogenic emission of dimethylsulfide (DMS) from the North Yellow Sea, China and its contribution to sulfate in aerosol during summer, Atmos. Environ., 43, 2196-2203, 2009.

Yarwood, G., Rao, S., Yocke, M., and Whitten, G.: Updates to the Carbon Bond Chemical Mechanism: CB05. Report to the US EPA, RT-0400675, available at: http://www.camx.com/publ/ pdfs/CB05_Final_Report_120805.pdf, 2005.

Yin, F., Grosjean, D., and Seinfeld, J. H.: Photooxidation of dimethyl sulfide and dimethyl disulfide. I: mechanism development, J. Atmos. Chem., 11, 309-364, 1990.

Yvon, S. A. and Saltzman, E. S.: Atmospheric sulfur cycling in the tropical Pacific marine boundary layer $\left(12^{\circ} \mathrm{S}, 135^{\circ} \mathrm{W}\right)$ : a comparison of field data and model results 2 . sulfur dioxide, J. Geophys. Res, 101(D3), 6911-6918, 1996.

Zaveri, R. A: Development and Evaluation of a Comprehensive Tropospheric Chemistry Model for Regional and Global Applications, Ph.D. dissertation, Virginia Polytechnic Institute and State University, 250 pp., 1997.

Zhu, L.: Aqueous Phase Reaction Kinetics of Organic Sulfur Compounds of Atmospheric Interest, Ph.D. dissertation, School of Earth and Atmospheric Sciences, Georgia Institute of Technology, 261 pp., 2004.

Zhu, L., Nenes, A., Wine, P. H., and Nicovich, J. M.: Effects of aqueous organosulfur chemistry on particulate methanesulfonate to non-sea salt sulfate ratios in the marine atmosphere, J. Geophys. Res., 111, D05316. doi:10.1029/2005JD006326, 2006. 